\title{
Fehérje interakciók az ecetmuslica telomerének retrotranszpozonjain
}

\author{
Ph.D. értekezés
}

\section{Takács Sándor}

Témavezető: Dr. Török Tibor

\author{
Biológia Doktori Iskola \\ Szegedi Tudományegyetem \\ Természettudományi és Informatikai Kar \\ Genetikai Tanszék
}

2014.

Szeged 
A telomer 6

$\begin{array}{ll}\text { Az ecetmuslica telomere } & 8\end{array}$

Telomer hosszabbodás módjai $\quad 12$

$\begin{array}{ll}\text { Telomerikus fehérjék } & 14\end{array}$

CÉLKITÜZÉSEK 17

ANYAGOK ÉS MÓDSZEREK

$\begin{array}{lr}\text { Drosophila törzsek } & 18\end{array}$

$\begin{array}{ll}\text { Kromoszóma immunfestések } & 19\end{array}$

UV keresztkötés, formaldehid keresztkötés és kromatin tisztítás 19

$\begin{array}{ll}\text { GST-pulldown } & 20\end{array}$

BAC filterek és Southern blot hibridizáció $\quad 20$

A HeT-A, 2L TAS, jockey és $1,686 \mathrm{~g} / \mathrm{ml}$ szatellita DNS fragmentumai 20

RNS kivonás petefészekből és DNS kivonás a légy többi szövetéböl 21

cDNS szintézis $\quad 22$

Kvantitatív Real-Time PCR (qPCR) 22

Élesztő két-hibrid kísérlet $\quad 23$

$\begin{array}{ll}\text { Immunprecipitáció } & 24\end{array}$

EREDMÉNYEK

A Prod fehérje eukromatikus szerepének vizsgálata 25

A Prod fehérje a telomerek HTT sorához kötődik 26

A Prod fehérje közvetlenül a HeT-A elem promótere elé kötődik 30

A Prod a HeT-A transzkripció represszora lehet 35

Élesztő két-hibrid szürés 38

A Prod közvetlenül köti a Chromator-t in vivo 41

A fehérjék telomerikus lokalizációja immunfestések alapján 43 
A Prod szerepe a HTT kromatin szumoiláltságában

Telomerhossz heterozigóta mutánsokban

EREDMÉNYEK MEGVITATÁSA 54

A HTT kromatinszerkezete 54

A Prod szerepe a HTT doménen 54

A Prod-Chro interakció szerepe 57

A szumoiláció szerepe a HTT domén müködésében

KÖSZÖNETNYILVÁNÍTÁS 62

IRODALOMJEGYZÉK 63

ÖSSZEFOGLALÁS 72

SUMMARY 77 


\section{BEVEZETÉS}

\section{A Prod fehérje}

Kutatócsoportunk az ecetmuslica proliferation disrupter (prod) génjének funkcióit vizsgálta. A prod gén egy 346 aminosavból álló DNS-kötő kromoszómális fehérjét kódol, mely megtalálható a második és harmadik kromoszómák centromer környéki heterokromatinján, több száz eukromatikus lókuszon, valamint az összes telomeren. Blast keresés alapján a Prod fehérje a Drosophila genusra specifikus.

Legelöször a fehérje heterokromatikus funkcióját sikerült felderíteni (Török és mtsai., 2000). A Prod fehérje erősen kötődik a második és harmadik kromoszómák centromerét határoló centromerikus heterokromatinhoz, azon belül is egy $1,686 \mathrm{~g} / \mathrm{cm}^{3}$ fajsúlyú $10 \mathrm{bp}$-os szatellita (ProdSat) DNS ismétlődéshez, amely mintegy 2 Mbp hosszúságú blokkokat alkot mindkét kromoszómán (1. ábra). A homozigóta prod null mutáció késői lárva állapotú letalitást okoz. A mutáns lárvák mitotikus sejtjei csökkent mitotikus indexet, anafázisos hibákat és kromoszóma kondenzációs hibákat mutatnak. Ezek a fenotípusok minden bizonnyal a Prod fehérje ProdSat-ról való hiányának tudhatók be (Török és mtsai., 1997). Az organizmus szintjén ez az osztódóképes szövetek alulfejlettségében és nagymértékü sejthalálozásában mutatkozik meg, ami végső soron a lárvák pusztulásához vezet. A géntermék minden sejtben szükséges, de a prod mutánsok embriogenezisét a nagy mennyiségü anyai eredetü géntermék lehetővé teszi (Török és mtsai., 1997).
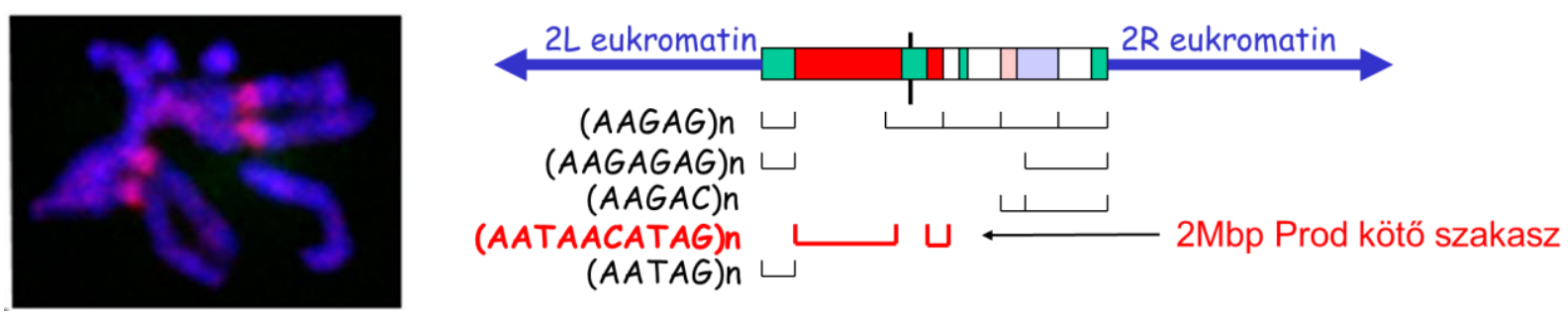

1. ábra. A Prod fehérje (piros festés a baloldali ábrán) mitózis során a 2 . és 3 . kromoszómák centromerjeinek közelében lokalizált, ahol a ProdSat ismétlődő szekvenciákhoz kötődik, melynek eloszlását a 2 . kromoszómán a jobboldali ábra mutatja. 
A Prod a ProdSat heterokromatinon közvetlenül, gyenge affinitással és szekvenciaspecificitással, kooperatívan köti a DNS-t (Török és mtsai., 2000). Nincs jól jellemezhető DNS-kötő doménje, a fehérje 2/3-a szükséges a DNS kötéséhez. Kísérleteink szerint, ha a fehérje N-terminális 74 aminosava hiányzik, a szekvencia-specificitás elvész, de a kooperatív DNS-kötés képessége megmarad (Török és mtsai., 2000). Ez arra utal, hogy a kooperativ fehérje-fehérje kölcsönhatás nélkülözhetetlen lehet a DNS-kötéshez, melynek igen alacsony a szekvencia-specifitása. A fehérje közepén egyetlen coiled-coil domén azonosítható, ami tipikus fehérje interakciós domén, és valószínűleg ez lehet felelős a kooperatív interakciókért.

Szekvencia analízis alapján a Prod gén regulátor szakasza nagy valószínüségü PRE-t (Polycomb Response Element) tartalmaz, vagyis a Polycomb csoport tagjai részt vehetnek a Prod finom regulációjában (Ringrose és mtsai., 2003). Mivel a Polycomb fehérjék közismerten egymás regulátorai, ez alapján esetleg a Prod is része lehet valamely Polycomb komplexnek.

A ProdSat-on kívül a fehérje több mint 400 eukromatikus helyen is kimutatható immunfestéssel (2. ábra).

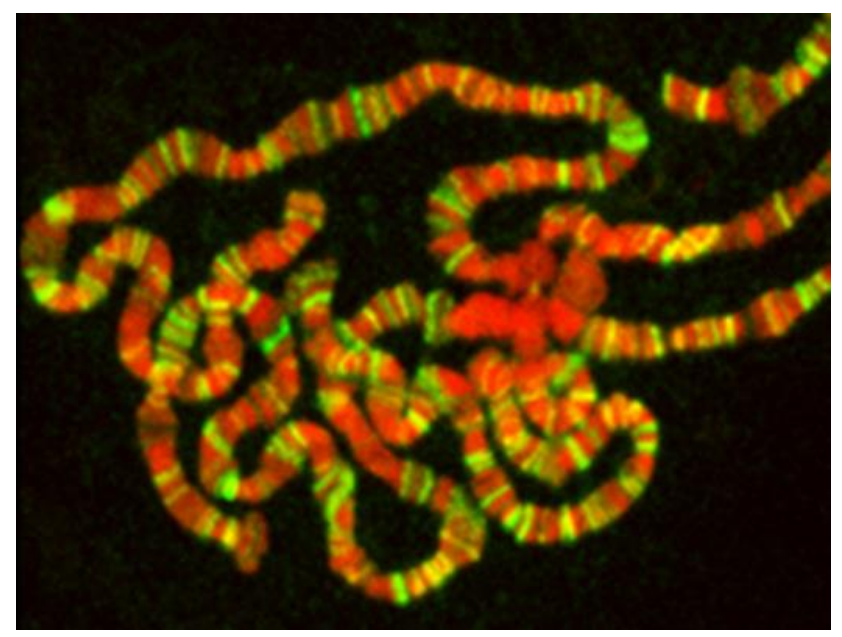

2. ábra Ecetmuslica lárva nyálmirigy politén kromoszómájának Prod festése. A DNS propídium-jodiddal (piros), a Prod fluoreszceinnel (zöld) festett, ezért a Prod fehérje az interband régiókban zöld, a nagyobb DNS tartalmú band régiókban pedig sárga színnel festődik a kromoszómán.

A fehérje eukromatikus lókuszokon betöltött szerepét számos kísérlettel próbáltuk vizsgálni, de egyik sem hozott számottevő eredményt, pedig több adat is alátámasztja a fehérje fontos szerepét az eukromatinon. Ezek közül az egyik leglényegesebb az evolúciós bizonyíték. A Drosophila melanogaster-rel legközelebbi rokon fajokban (D. mauritiana és D. simulans) a 99\%-ban azonos szekvenciájú géntermék kizárólag az eukromatinhoz kötődik, mivel ezen fajokban hiányzik a $D$. melanogaster-nél meglévő ProdSat szatellita szekvencia (Csink és Henikoff, 1998) (3. ábra). 


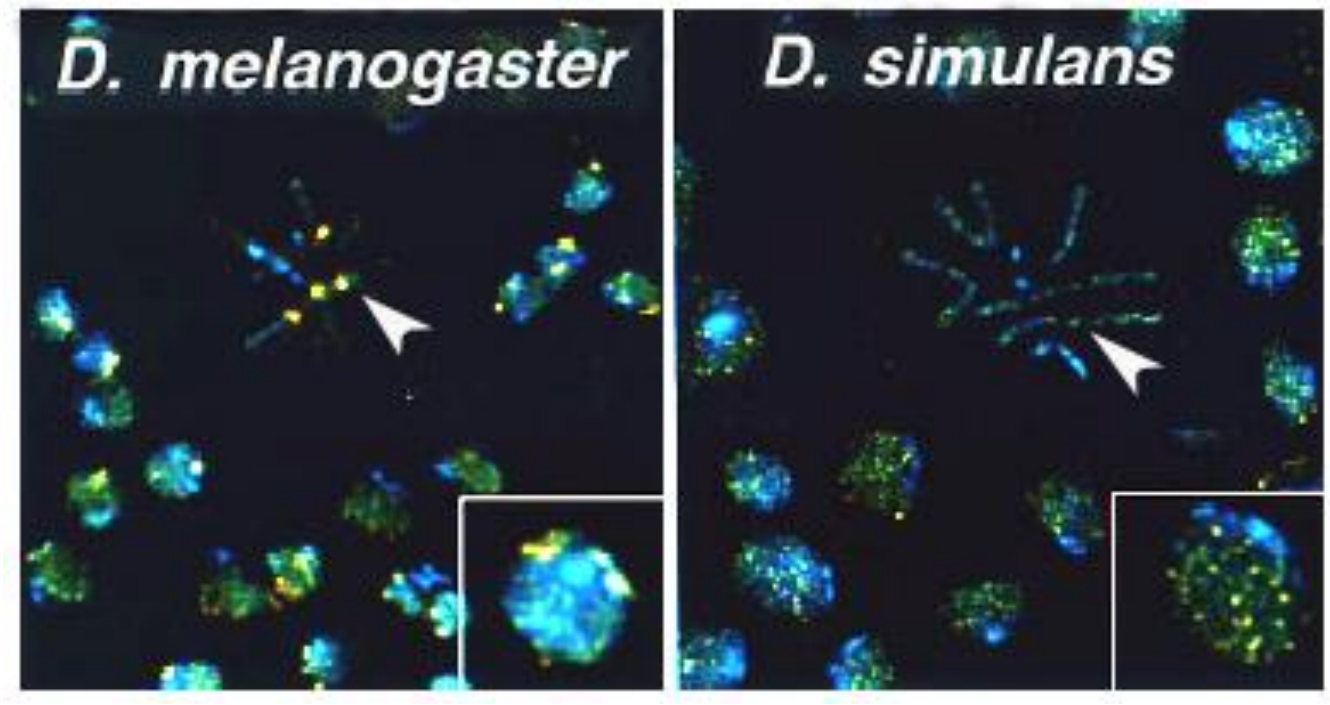

3. ábra. A Prod fehérje eloszlása rokon Drosophila fajok diploid koromoszómáin (DAPI - kék; Prod - sárga). D. simulans-ból (és D. mauritiana-ból) hiányzik a heterokromatikus ProdSat célszekvencia, ezért nem mutatnak Prod halmozódást a centromer közelében (nyílhegyek), de a kromoszóma karok sárgás pöttyözöttsége jelzi, hogy az eukromatikus kötőhelyek megvannak (Csink és Henikoff, 1998).

Ez alapján ezen fajokban a Prod fehérjének nincs heterokromatikus funkciója, csakis eukromatikus, ami evolúciósan elsődleges kellett hogy legyen. Az eukromatikus kötőhelyek D. melanogaster-ben a rokon fajokhoz hasonló kromoszómális eloszlást mutatnak (Csink és Henikoff, 1998). A Prod fehérje túltermelése D. melanogasterben kifejeződési mintázattól függően súlyos fejlődési rendellenességeket, vagy letalitást okoz (4. ábra), ami nem magyarázható osztódási hibákkal, csakis génmüködési hibákkal (Török és mtsai., 1997) (nem közölt eredmény). Szomatikus mutáns klónokban megfigyelhető rendellenességek sem kizárólag osztódási hibára utalnak, súlyos differenciálódási hibák is megfigyelhetők, ami megint csak eukromatikus funkcióra utal (Török és mtsai., 1997). 


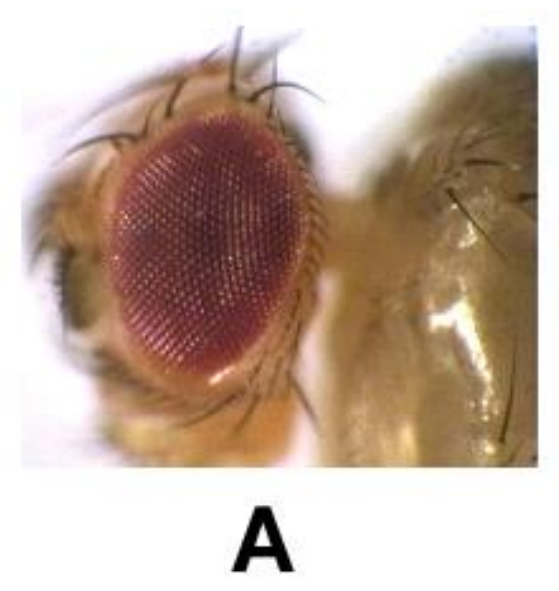

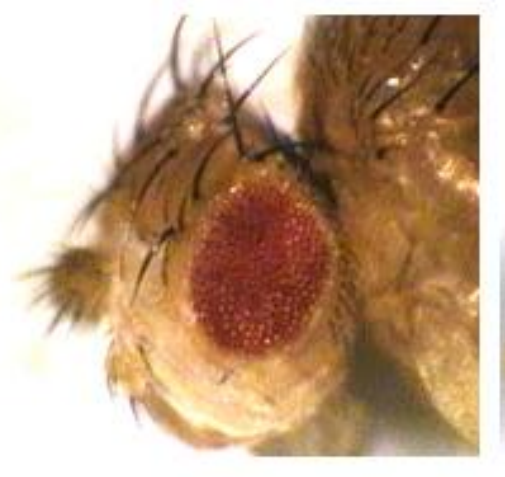

B

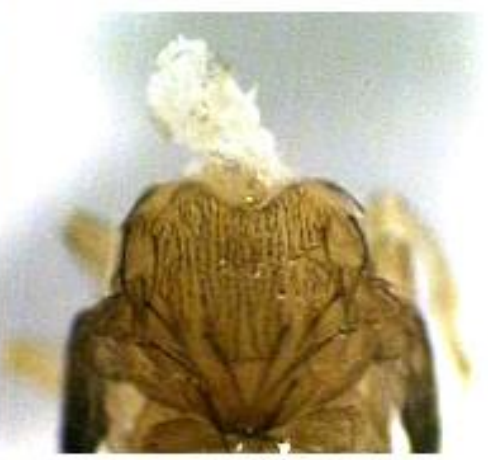

C

4. ábra. A Prod fehérje túltermeltetése ecetmuslica fejben. Vad típushoz (A) hasonlítva jól látható enyhébb (B) és komolyabb (C) fejlődési rendellenességek figyelhetőek meg, ha a Prod fehérjét eyeless promóter segítségével fejben túltermeltetjük (Török, nem közölt eredmény).

A Prod fehérje és a Trithorax-like gén által kódolt transzkripciós aktivátor, a GAGA faktor egymáshoz hasonló citológiai eloszlást mutat a sejtciklus során (Csink és Henikoff, 1998; Platero és mtsai., 1998; Raff és mtsai., 1994). Interfázisos kromoszómákon mindkét fehérje elsősorban az eukromatinon található, ahol génszabályozó szerepük lehet, míg mitózis során mindkettő a pericentrikus szatelliták kötőhelyeire vándorol, ahol nélkülözhetetlenek a rájuk jellemző specifikus pericentrikus heterokromatin szekvenciák kondenzációjához, ami elengedhetetlen a centromer megfelelö müködéséhez (Platero és mtsai., 1998).

\section{A telomer}

Mivel a jelen dolgozatban közölt eredmények elsősorban a Prod fehérje telomerikus funkciójára vonatkoznak, ezért röviden bemutatom a telomerek általános szerkezetét és funkcióját, majd részletesen ismertetem, hogy mit tudunk az ecetmuslica sajátos telomer szerkezetéröl.

Az eukarióta telomerek olyan nukleoprotein komplexek, melyek védik a lineáris kromoszómák végeit a degradációtól és a fúziótól, valamint kiegyensúlyozzák a tökéletlen replikáció természetéből adódó rövidülést. A telomerek megfelelő müködése a telomerikus ismétlődések hosszától és a hozzájuk kapcsolódó fehérje komplexektől függ. 
A kromoszómák legvégső része a „cap”, melyre az életképesség szempontjából minden kromoszómavégen szükség van. Számos fehérje alkotja ezt a struktúrát, melyek a telomerázzal rendelkező eukarióta élőlényekben fajtól függően terminális DNS szekvenciát ismernek fel, bár néhány tagjuk szekvenciától függetlenül is kapcsolódhat a DNS-hez (Mason és mtsai., 2008). Ha a telomerek nincsenek megfelelően „sapkázva” (capping), semmi nem különbözteti meg őket egy kettős szálú kromoszómatöréstől, ami a hiba kijavításáig a sejtciklus megakasztásához és apoptózishoz is vezethet (Mason és mtsai., 2008). Humán telomereken (5. ábra) a telomeráz által szintetizált TTAGGG ismétlődések visszahajolva tloop-ot képeznek, amit cap fehérjék stabilizálnak (pl.: TRF1, TRF2, RAP1). Ez az úgynevezett „shelterin” komplex védi meg a kromoszómavéget a DNS repair rendszertől, valamint szabályozza a telomeráz hozzáférését a telomerhez (Chan és Blackburn, 2002).

A telomerek minden sejtosztódással rövidebbek lesznek, aminek az oka az, hogy a DNS polimerázok nem képesek a 3' $\rightarrow 5$ ' irányú szintézisre, így a lemaradó szálon a polimeráz képtelen lecserélni az utolsó RNS primer nukleotidjait. Ezért minden lineáris kromoszómával rendelkező élőlénynek szüksége van egy speciális folyamatra, mely kiegészíti a kromoszómavégeket, mielőtt azok végzetesen lerövidülnének. Ezt a kromoszómavégek replikációjából adódó problémát a legtöbb organizmusban a telomeráz enzim oldja meg (Mason és mtsai., 2008). Ez a reverz transzkriptáz rövid (5-10 bp), G+T-gazdag ismétlődésekkel toldja meg a kromoszómavégeket fajra jellemző RNS templátot használva (Pardue és DeBaryshe, 2003). Többsejtű eukarióta élőlényekben kromoszómavégenként jellemzően 10-15 kb hosszú ez a telomerikus ismétlődésekből álló szakasz.

A telomerázzal rendelkező organizmusok egyéb módon is képesek meghosszabbítani a telomerüket, egy rekombináció alapú mechanizmussal, génkonverzióval egészíthetik ki vagy pótolhatják a hiányzó telomer szekvenciákat (Pardue és DeBaryshe, 2003).

A telomeráz által létrehozott repetitív DNS szakasz mellett a telomerek másik jellemzője a szintén repetitív blokkokból álló TAS (telomere-associated sequences) is, melyet szubtelomerikus repetitív régiónak is neveznek. Elrendeződése és szekvenciája fajonként eltérő, de egyazon sejt különböző telomerein is változó összetételű (Pryde és mtsai., 1997).

A telomerek feladata nem merül ki pusztán a kromoszómavégek védelmében. Fontos szerepet tölthetnek be a ,sejtkarbantartás”, öregedés, genomstabilitás vagy az karcinogenezis folyamatában is (Cenci és mtsai., 2005; Chan és Blackburn, 2002; Schoeftner és Blasco, 2009), ennek mechanizmusa azonban még nem ismert. 


\section{Az ecetmuslica telomere}

Az ecetmuslica (Drosophila melanogaster) és más Drosophila fajok kromoszómavégei telomeráz által létrehozott ismétlődések helyett telomer-specifikus retrotranszpozonokat tartalmaznak (Pardue és DeBaryshe, 2003). Az ecetmuslicából a telomeráz enzim teljesen hiányzik, így a telomer három, non-LTR (terminális ismétlődést nem tartalmazó) retrotranszpozon, a $\underline{H} e T-A, \underline{T A R T}$ és $\underline{T A H R E}$ (továbbiakban HTT) elemek kromoszómavégre történő célzott transzpozíciójával, valamint ezen elemek közötti homológ rekombinációval hosszabbodik (Mason és Biessmann, 1995; Melnikova és mtsai., 2005; Pardue és DeBaryshe, 2003) (6. és 7. ábra). Szerkezetileg az ecetmuslicában is három telomerikus domént tudunk megkülönböztetni: a kromoszómális DNS molekula szabad végét; a retrotranszpozon ismétlődést (HTT sor), valamint a szubtelomerikus heterokromatint, más néven TAS-t (Biessmann és mtsai., 2005a). Bár a telomerikus DNS szekvenciák jól jellemzettek, a hozzájuk kapcsolódó kromatin fehérjékről szerzett tudásunk még messze nem teljes.

\section{Drosophila}
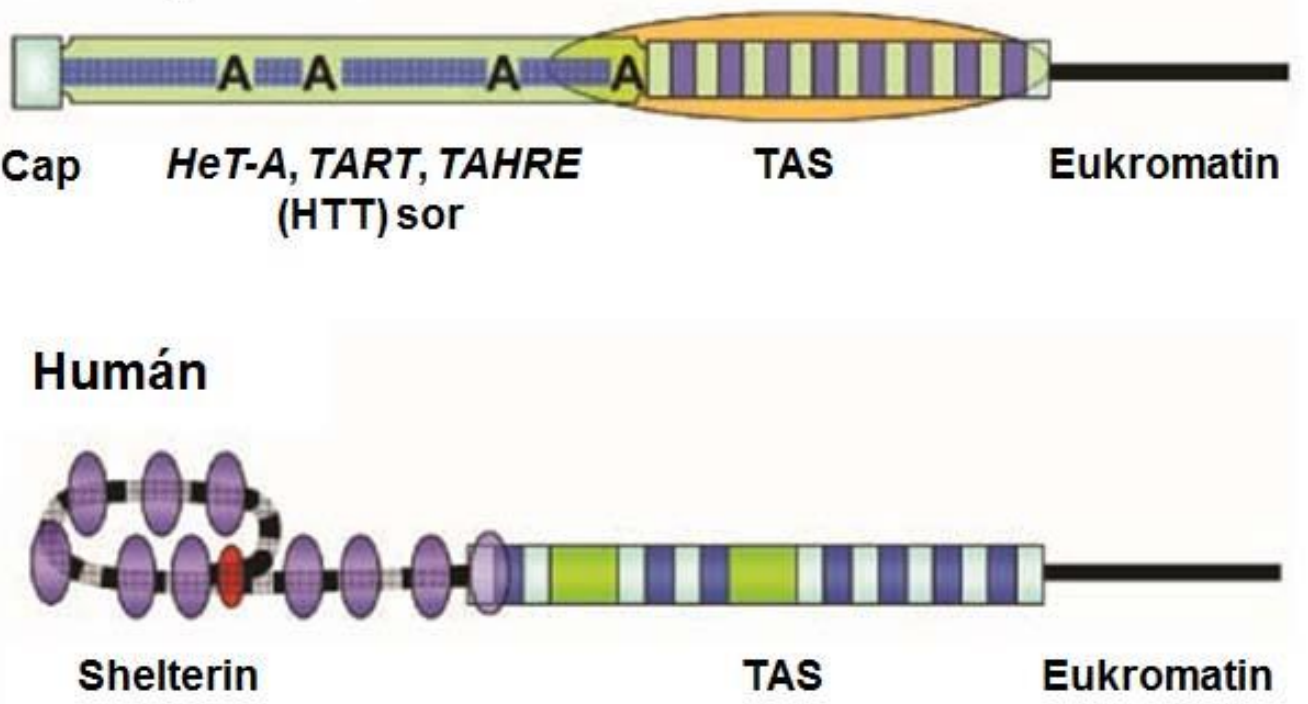

5. ábra. A Drosophila és az emlős telomerek általános szerkezetének összehasonlítása. Ecetmuslicában a capping komplex (kék négyzet) fehérjéi szekvencia-specificitás nélkül kötődnek a kromoszóma végéhez. A HTT sort a három telomer-specifikus non-LTR retrotranszpozon tandem ismétlődései alkotják, melyek oligo(A) farka (A-val jelölve) mindig a centomer felé néz. Ez a domén eukromatikus szerkezetü, és olyan fehérjék kapcsolódnak ide (zöld téglalap), amelyek 
megtalálhatóak más kromoszóma szakaszokon is. A szubtelomerikus ismétlődések (TAS) heterokromatikus szerkezetủek, (narancssárga ovális), amely kiterjed a HTT szakasz közeli régiójára is. Humán sejtekben a telomeráz által létrehozott TTAGGG ismétlődések t-loop struktúrát alkotnak, amit speciális fehérjék stabilizálnak (vörös ovális). A telomerikus repeatekhez kötődő fehérjék (lila ovális) heterokromatikus csendesítő komplexet képeznek (telosome/shelterin), ami a TAS régióra is ráterjedhet. Ebben az esetben az egész telomer szorosan csomagolt, heterokromatikus szerkezetü (Mason és mtsai., 2008).

Egy generáció alatt az ecetmuslica telomerek 70-75 nukleotiddal rövidülnek, (Biessmann és Mason, 1988), míg egy teljes méretü retrotranszpozon beépülése több ezer bázispáros hosszabbodáshoz vezet. Ezért a normális telomerhossz fenntartása a transzpozíciók szigorú szabályozását követeli. A három különböző HTT elem beépülésének lehetősége és a kromoszómavég fokozatos degradációja változatos terminális nukleotid szekvenciákat eredményez különböző egyedekben és ugyanazon egyed különböző sejtjeiben is. A kromoszómavégek szekvenciáinak változatossága is megkülönbözteti az ecetmuslica telomert a telomeráz által fenntartott telomerektől. Még nem tisztázott, hogy a Drosophila telomer 3' túlnyúló vége a gerinces telomerekhez hasonló t-loop szerkezetet alakít-e ki.

(A) Terminális kromoszóma capping komplex: Az ecetmuslica kromoszómák szabad végei természetes állapotban telomerikus retrotranszpozonokban végződnek (Biessmann és mtsai., 1993). Ezek a retrotranszpozonok azonban nem létfontosságúak a kromoszómavégek szerkezeti integritásához, mivel a terminálisan deletált kromoszómák, végződjenek azok bármilyen szekvenciával, képesek a terminális komoszóma capping fehérje komplex megkötésére, amely a szabad végeket stabilizálja, így a terminálisan deletált kromoszómák is funkcióképesek maradnak és stabilan átöröklődnek (Biessmann és mtsai., 1990; Biessmann és Mason, 1988). A nagyszámú fehérjéből álló terminális capping komplex megvédi a kromoszómavéget attól, hogy azt a DNS repair mechanizmus kettős szálú törésként ismerje fel. Humán telomeren ez a komplex a telomeráz enzim által képzett TTAGGG szekvenciájú terminális ismétlődésekhez kötődik, míg ecetmuslicában szekvencia-specifitás nélkül kapcsolódik a kromoszómavégekhez. A capping komplex komponenseinek hiányában (pl. ezen fehérjéket kódoló gének mutációja miatt) a kromoszómavégek védtelenné válnak, mely telomer-telomer fúziót mutató anafázis hidak kialakulásához és sejthalálhoz vezet (Cenci és mtsai., 2005). A komplex fehérjéit a későbbiekben ismertetem. 
(B) A retrotranszpozon sor (HTT): A Drosophilidae családra jellemző egyedi domén. Mindhárom HTT sort alkotó retrotranszpozon (HeT-A, TART, TAHRE) a LINE (long interspersed nucleic elements) típusú retroelemek közé tartozik (Arkhipova és Morrison, 2001), de hiányzik belőlük a többi retrotranszpozonra jellemző hosszú terminális ismétlődés (LTR). A három retroelem (6. ábra) különböző összetételben található meg az ecetmuslica telomerein. A leggyakoribb a reverz transzkriptázt nem kódoló HeT-A retrotranszpozon, amelyből kb. 30 kópia van jelen a Drosophila genomban, a reverz transzkriptázt kódoló TART (telomere-associated retrotransposon) elemből átlagosan 10 példány található (Abad és mtsai., 2004a; George és mtsai., 2006; Levis és mtsai., 1993; Sheen és Levis, 1994), a TAHRE (telomere-associated and $\underline{H} e T-A$-related element) elemből mindössze négy kópiát tartalmaz az átlagos genom és abból is csak egy teljes méretü (Abad és mtsai., 2004a, b).

A telomerek számos 5' végen csonkolt elemet is hordoznak, ami vagy a reverz transzkriptáz korai leállásával, vagy a következő retroelem korai, a replikáció befejezte előtti beépülésével magyarázható. A TART és TAHRE elemek (leghosszabb kópiájuk 16 kb, illetve $\sim 11 \mathrm{~kb}$ méretü) két open reading frame-et (ORF), valamint kiterjedt 5' és 3' nem kódoló régiókat tartalmaznak. Az első ORF egy cink-ujj fehérjét kódol, ami a retrovirális RNS-kötő GAG fehérje homológja (Pardue és mtsai., 1996). A második ORF által kódolt fehérje endonukleáz és reverz transzkriptáz doménnel rendelkezik. A TART és TAHRE elem második ORF-je nagyfokú hasonlóságot mutat. A HeT-A retrotranszpozon $(\sim 6 \mathrm{~kb})$ erős homológja a TAHRE elemnek (különösen a 3' és 5' nem transzlálódó régiók), azonban hiányzik belőle a második, reverz transzkriptázt kódoló ORF. Így a HeT-A egy nem-autonóm elemnek tekinthető, amely valószínüleg az autonóm TAHRE retrotranszpozonból keletkezett, és transzpozíciójához a TART és/vagy TAHRE elem reverz transzkriptáz enzimére van szükség. A HeT-A és TAHRE elemek promótere a 3'UTR (untranslated region - nem átíródó régió) szakaszuk utolsó 600 bp szakaszán található, ami rendhagyó módon a szomszédos elem szekvenciáinak átírását irányítja (Danilevskaya és mtsai., 1997; Kahn és mtsai., 2000). A TART elemen több promótert is azonosítottak az elem mindkét szálán (Danilevskaya és mtsai., 1999; Maxwell és mtsai., 2006). 


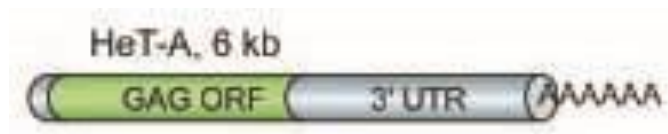

TAHRE, $10 \mathrm{~kb}$

CC GAG ORF C RTOAF C SUTR BAAAA

TART, $11-13 \mathrm{~kb}$

GAG ORF C RTORF BUTR GAMMA

6. ábra. A három telomerikus retrotranszpozon (HeT-A, TAHRE, TART) összehasonlítása. Mindhárom elem legalább 3 kb hosszú 3' UTR szakaszt hordoz. Az elemek a 3' oligo(A) faroknál (AAAAAA) fogva kapcsolódnak a kromoszómavégekhez (Capkova Frydrychova és mtsai., 2008).

A HTT domént nyíltabb, eukromatin-szerü szerkezet jellemzi (Biessmann és mtsai., 2005b). A retrotranszpozon sor hosszát és összetételét tekintve jelentős különbség lehet az egyes kromoszómavégek és egyes törzsek között is, de a telomerek hossza egy bizonyos határig genetikailag szabályozott az ecetmuslicában is (Abad és mtsai., 2004a; Biessmann és mtsai., 1997; Walter és mtsai., 1995). A hosszkülönbségek jelentősége és következményei még nem tisztázottak, de a túlzottan hosszú HTT sor csökkenti az állat termékenységét (Walter és mtsai., 2007).

(C) A szubtelomerikus repetitív régió (TAS): A szubtelomerikus ismétlődő szakasz (TAS) - amely a HTT doménnel közvetlenül szomszédos és attól proximális irányban helyezkedik el - 15-26 kb hosszúságú, és komplex ismétlődő szekvencia blokkokból áll (Abad és mtsai., 2004a; Mason és mtsai., 2003b), melyek kromoszómánként némileg eltérnek (Karpen és Spradling, 1992; Walter és mtsai., 1995). A TAS szorosan csomagolt heterokromatikus kromatinszerkezetére utal, hogy csökkenti a doménbe inszertálódott marker gének aktivitását. Ezen telomerikus transzgének kifejeződése gyakran hasonló a pericentrikus heterokromatin közelébe került eukromatikus gének pozíció effektus variegáció (PEV) fenotípusához. A telomeren fellépő ilyenfajta géncsendesítést Telomerikus Pozíció Effektusnak (TPE) nevezik. A TAS pontos funkciója kevéssé tisztázott, valószínúleg a HTT retrotranszpozonok aktivitását befolyásolja, illetve elszigeteli a telomert a kromoszóma többi részétől. 


\section{Telomer hosszabbodás módjai}

A Drosophila telomer szokatlan szerkezete felveti a kérdést, hogy a terminális retrotranszpozonok aktivitása hogyan szabályozódik. A csökkent aktivitás egyre rövidebb telomert, végül a legkülsőbb eukromatikus gének elvesztését eredményezi, míg a fokozott aktivitás hosszabb telomerek kialakulásához vezet, ami szintén káros következményekkel jár (Walter és mtsai., 2007).

A 7. ábra egy HTT elem retrotranszpozíciójának modelljét ábrázolja. Az első lépés a transzpozon transzkripciója, melyet a szomszédos (upstream) HeT-A elem 3' UTR szakaszán található promóter irányít. A transzkriptum kilépve a sejtmagból mRNS-ként szolgál a kódolt polipeptid(ek) transzlációjához. A kódolt GAG fehérje átíródása után a retroelem RNS-éhez kötődik, majd három sejtmagi lokalizációs szignálja biztosítja, hogy a GAG-RNS komplex visszajusson a sejtmagba (Rashkova és mtsai., 2002a; Rashkova és mtsai., 2002b). A kromoszómavéghez történő dokkolás a GAG-fehérje és a terminális capping komplex közötti fehérje-fehérje kölcsönhatás segítségével mehet végbe. A kromoszómavégi szabad 3' véghez kapcsolódó RNS templátként szolgál a reverz transzkriptáz számára, amely a HeT-A mRNS-t egyszálú DNS-sé írja át. A második szál szintézisét a DNS repair rendszer végzi, és ezzel befejezi az új retrotranszpozon beépítését. A telomerikus traszpozonok mutációk miatti fokozatos inaktivációját a funkcionális GAG-ORF-fel rendelkező elemek pozitív szelekciója akadályozhatja meg (Abad és mtsai., 2004a; Biessmann és mtsai., 1992a). 


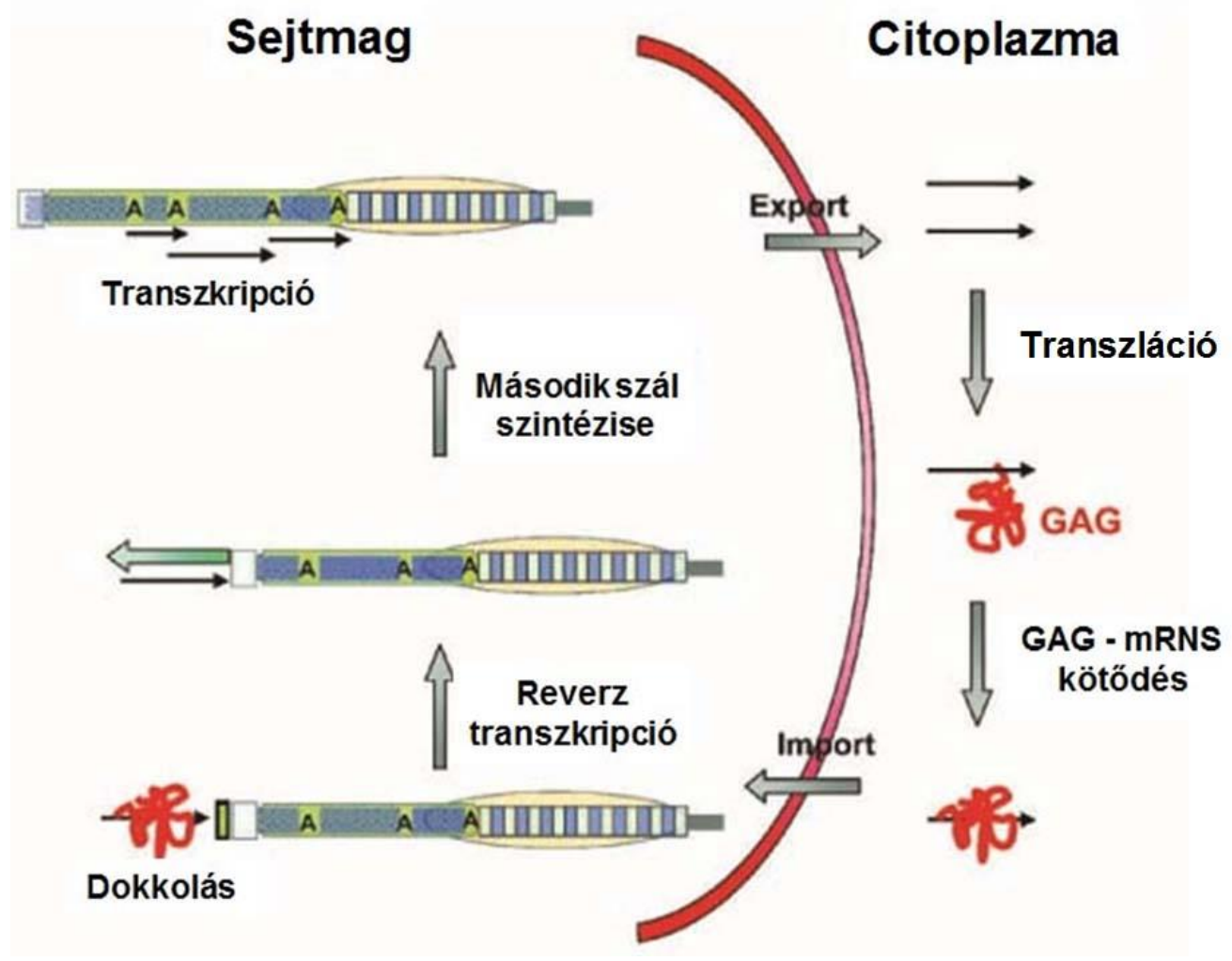

7. ábra. Retrotranszpozíció általi telomer hosszabbodás sejtmagi és citoplazmatikus eseményei ecetmuslicában (Mason és mtsai., 2008). Részletes magyarázatot lásd a szövegben.

Néhány kísérleti adat arra utal, hogy a telomerikus retrotranszpozonok aktivitását RNS interferencián (RNSi) alapuló mechanizmusok is szabályozhatják az mRNS mennyiségének befolyásolásával, különösen a TART elem esetén, melynek mindkét száláról képződik transzkriptum (Danilevskaya és mtsai., 1999; Walter és Biessmann, 2004). A TART és HeT-A elemek transzkriptum szintje ugyanis megemelkedik a csíravonalban néhány RNSiútvonalban szerepet játszó gén, mint például a spn-E (RNS helikáz) és az aub (Argonaute család) mutációja esetén (Savitsky és mtsai., 2006). Ez az emelkedett transzkriptum szint 100-szorosára emelte az új TART transzpozíciók számát egy törött X kromoszómavégre, de nem volt hatással a HeT-A beépülések gyakoriságára. Meglepő módon a magasabb HeT-A és TART transzkriptum szintek ellenére sem a spn-E, sem az aub mutánsoknak sincs észrevehetően hosszabb HTT szakasza (Melnikova és mtsai., 2005). Ennek oka vélhetően az, hogy egy bizonyos hosszt elért telomerek (valószínüleg a t-loop szerkezet miatt) védetté válnak a további transzpozíciós hosszabbodással szemben. 
Törött X kromoszómavégek tanulmányozásakor a retroelem transzpozíció mellett terminális génkonverziót is megfigyeltek. Génkonverzió esetén a teljes hosszúságú $X$ homológról került át szekvencia a törött $\mathrm{X}$ végre. Capkova Frydrychova és mtsai eredményei szerint ily módon átlagosan 2,7 kb nagyságú darabbal hosszabbodott a törött vég (Capkova Frydrychova és mtsai., 2008). Bár a telomer hosszabbodás fő mechanizmusának továbbra is a retrotranszpozíciót tartják, a fenti eredmények azt mutatják, hogy a terminális génkonverziónak is jelentős szerepe lehet ebben a folyamatban.

\section{Telomerikus fehérjék}

A fent vázolt telomerikus domének nem csak a DNS szekvencia, hanem a hozzájuk kapcsolódó kromatin fehérjék szintjén is elkülöníthetőek. Hogy megértsük a telomerhossz szabályozásának mechanizmusát, elengedhetetlen a telomer kromatin szerkezetének és fehérje összetételének ismerete.

Genetikai és citológiai módszerekkel a terminális capping komplexet alkotó fehérjék közül azonosították a legtöbbet. A komplex legfőbb alkotói a HP1 (ㅌeterochromatin Protein

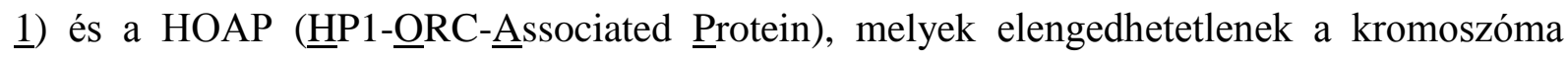
stabilitásához (Andreyeva és mtsai., 2005; Cenci és mtsai., 2003; Fanti és mtsai., 1998; Fanti és Pimpinelli, 2008; Shareef és mtsai., 2001). A Su(var)205 gén által kódolt HP1 fehérje a kromoszómavég védelmében, a telomerhossz homeosztázisában és a telomerikus retrotranszpozonok transzkripcionális repressziójában is szerepet játszik (Perrini és mtsai., 2004; Savitsky és mtsai., 2002). A Su(var)205 mutánsokban megemelkedik a HeT-A transzkriptum szintje, amit annak tulajdonítanak, hogy a HP1 kis mennyiségben a HTT doménen is kimutatható és transzkripciós represszorként viselkedik, a Su(var)205 mutánsokban pedig ez a represszor aktivitás lecsökken (Frydrychova és mtsai., 2008). Ugyanezen mutánsokban nő a telomerek hossza is, mivel megemelkedő HTT transzkripció mellett a capping funkció is sérül, ami megnövekedett mértékü retrotranszpozícióhoz, terminális génkonverzióhoz és hosszabb telomerek kialakulásához vezethet (Savitsky és mtsai., 2002; Török és mtsai., 2007). A HP1 a kromoszómavégeken közvetlenül köti a DNS-t, míg a kromoszómális kötőhelyeken a hiszton $\mathrm{H} 3$ metilált formájához (H3K9me3) kapcsolódva hoz létre represszív kromatinszerkezetet (Perrini és mtsai., 2004). A cap-et alkotó fehérjék hiányában telomer fúzió alakul ki, ami mitózis hibákat eredményez. Ezen 
jellegzetes mitotikus mutáns fenotípus segítségével azonosították a cap-et alkotó legtöbb fehérjét, így a HiPHop (HP1-HOAP-interacting protein) (Gao és mtsai., 2010), a Moi (Modigliani) (Komonyi és mtsai., 2009; Raffa és mtsai., 2009), a Ver (Verrocchio) (Raffa és mtsai., 2010), az ATM (̂taxia Telangiectasia Mutated) (Bi és mtsai., 2004), a Woc (Without Children) (Raffa és mtsai., 2005) fehérjéket, valamint az MRN komplexet (Mre11/Rad50/Nbs) (Bi és mtsai., 2005; Bi és mtsai., 2004; Ciapponi és mtsai., 2004).

A TAS-hoz kapcsolódó fehérjék közül csak néhányat azonosítottak (PC, E(z)), melyek a Polycomb-csoport (PcG) tagjai. Ezek a transzkripciós represszorok azonban nem találhatóak meg az összes telomeren (Andreyeva és mtsai., 2005; Boivin és mtsai., 2003). Mivel a TAS TPE-t okoz (Cryderman és mtsai., 1999; Golubovsky és mtsai., 2001; Mason és mtsai., 2003b), ezért a variegációt befolyásoló mutációk további vizsgálatával minden bizonnyal újabb TAS-kötő fehérjék génjei azonosíthatóak. Immunlokalizáció alapján a TAS régióról hiányzik a heterokromatinra jellemzö HP1 fehérje és a H3K9me3 hiszton módosulás, melyek a centromer környéki heterokromatin kialakításában fontos szerepet játszanak (Andreyeva és mtsai., 2005). A hiányuk arra enged következtetni, hogy a TPE és a PEV eltérő genetikai szabályozás alatt állhat.

A HTT sorhoz kapcsolódó fehérjéket nehéz azonosítani, mert a capping komplex és a TAS fehérjéivel ellentétben a HTT-kötő fehérjék génjeinek nincs megjósolható mutáns fenotípusa, ami egy hatásos genetikai szürés előfeltétele lenne. Ezért az egyik lehetséges módszer az immunfestéssel telomerikus lokalizációt mutató kromoszómális fehérjék vizsgálata. Ily módon eddig három HTT-kötő fehérje került azonosításra, a Prod, a Z4 és a JIL-1 (Andreyeva és mtsai., 2005), melyek mindegyike nagyszámú egyéb kromoszómális lókuszon is megtalálható a Drosophila genomban. Ezek mellett a cap alkotó HP1 kis koncentrációban ugyan, de a HTT és a TAS doménen is kimutatható kromatin immunprecipitációval (Frydrychova és mtsai., 2008).

A Z4 fehérjét a putzig (pzg) gén kódolja. A fehérje hét DNS-kötỏ cink-ujjat tartalmaz, és az óriáskromoszómák interband régióira specifikus kötődési mintázatot mutat. A pzg mutánsok a PEV haplo-szuppresszorai és triplo-enhanszerei (Eggert és mtsai., 2004), ami arra utal, hogy a géntermék a heterokromatin szerveződésében vesz részt. A pzg mutánsok politén kromoszómáinak morfológiája rendellenesen alulkondenzált (Eggert és mtsai., 2004). A mutáns fenotípusok alapján a Z4 fehérje a kromatin csomagolódásában játszhat szerepet és 
olyan határolóelemekhez kapcsolódhat, amelyek különböző kondenzáltságú doméneket választanak el. Ennek némileg ellentmond, hogy a Z4 fehérje jelenlétét két olyan fehérje komplexben is leírták melyek nyitott kromatinszerkezetet hoznak létre, a TRF2/DREF (Hochheimer és mtsai., 2002) és NURF (Kugler és Nagel, 2010) komplexekben. A TRF2/DREF (TATA-binding protein-related factor $\underline{2}$ és DNA replication-related element factor) komplex mag promótereket ismer fel és aktiválja a célgének transzkripcióját (Matsukage és mtsai., 2008), míg a NURF (nucleosome remodeling factor) komplex a nukleoszóma átépítést és elcsúszást katalizálja (Badenhorst és mtsai., 2002).

A JIL-1 kináz a H3 hisztont foszforilálja a 10. pozícióban lévő szerinen (Zhang és mtsai., 2006). A fehérje szerepe a nyitott kromatinszerkezet fenntartása, amit jól tükröznek a mutáns fenotípusok, ugyanis a csökkent JIL-1 müködést okozó mutációk a politén kromoszómák eukromatikus régióinak fokozott kondenzációját eredményezik (Deng és mtsai., 2005) és a PEV enhanszerei is (Bao és mtsai., 2007).

A telomereken jelenlévő hisztonmódosulásokat (Mason és mtsai., 2008) vizsgálták. A különböző hisztonmódosulatok a kromatin epigenetikus markerei lehetnek, melyek döntő módon meghatározzák a kromatinhoz kötődő fehérjéket, és a kromatin szerkezetét. Például a 4. pozícióban lévő lizin aminosavon trimetilált H3 hiszton (H3K4me3) transzkripcionálisan aktív kromatint jelöl, míg a H3K9me3 és a H3K27me3 az inaktív kromatin markerei. Politén kromoszómákon végzett immunhisztokémiai vizsgálat alapján H3K9me3 módosulás amelyhez a HP1 fehérje is kötődik - a HTT doménen megtalálható míg a TAS-on nem, ellenben a H3K27me3 a HTT-röl hiányzik, de a TAS-on és a cap-en jelen van. A heterokromatinra jellemző acetilált hiszton (H4K12ac) nincs jelen a telomereken, de a H3K4me3 megtalálható a HTT soron, vagyis a HTT domén egyaránt tartalmaz eukromatikus és heterokromatikus kromatin állapotokra jellemző módosulásokat. 


\section{CÉLKITÜZÉSEK}

Az ecetmuslica proliferation disrupter génje által kódolt Prod fehérje esszenciális szerepet tölt be a kromoszóma megfelelő csomagolódásában, hiánya letalitást okoz. Ez a kromoszómális fehérje a centromer környéki heterokromatin mellett több száz eukromatikus helyen és az összes telomeren is megtalálható. A Prod heterokromatikus funkcióját csoportunk korábban feltárta, további célunk a Prod eukromatikus lókuszokon és telomereken betöltött szerepének tisztázása volt. Az eukromatikus Prod-kötő szekvencia keresését célzó kísérletek kudarcát követően munkánk fókuszába a fehérje telomerikus jelenlétének vizsgálata került, melybe egy ismert telomer szakértő, Dr. Harald Biessmann kutatócsoportja is bekapcsolódott.

Célul tűztük ki azon telomerikus domén azonosítását, melyhez a Prod kötődik. Mivel a Prod-ot specifikusan kötő ProdSat DNS szekvencia a centromerikus heterokromatinon kívül máshol nem található meg a genomban, feltételeztük, hogy a Prod telomerikus kötődése is elsősorban fehérje-fehérje interakciókon keresztül valósul meg. Mivel a prod mutáció fenotípusát döntően megszabja a fehérje centromer közeli szerepe, ezért a telomerikus funkciót föként sejtbiológiai, molekuláris biológiai és biokémiai módszerekkel terveztük azonosítani.

Mivel a Prod mind az eukromatinon mind a telomeren nagy valószínüséggel fehérje komplexek része, ezért célul tüztük ki Prod-dal kölcsönható fehérje partnerek azonosítását élesztő két-hibrid szüréssel, majd az interakciók biokémiai és sejtbiológiai módszerekkel történő igazolásával.

A Prod fehérje telomerikus szerepének tisztázása hozzájárulhat a telomer müködésének és a kromatin szerveződésének mélyebb megértéséhez. 


\section{ANYAGOK ÉS MÓDSZEREK}

\section{Drosophila törzsek}

A következő törzseket a bloomingtoni törzsközpontból szereztük be: $\mathrm{Su}\left(\right.$ var) $205^{2} / \mathrm{CyO}$, mely egy pontmutációt hordoz a HP1 kromodoménjében (Eissenberg és mtsai., 1990); Su(var)205\% CyO, mely egy csonka HP1 fehérjét kódol, amiből hiányzik a magi lokalizációért felelős C-terminális domén (Eissenberg és mtsai., 1992); $P\{l a c W\} \operatorname{prod}^{k 08810} / C y O$, a prod egy null allélje, melyet az 5' nem transzlálódó régióba (UTR) inszertálódott $\mathrm{P}$ elem okozott a transzkriptum start kodonjától 13 bp távolságra upstream irányban (Török és mtsai., 1997). A $\operatorname{prod}^{H} / C y O$ egy EMS-indukált null mutáns egy stop kodonnal a 93. aminosav után (Török, nem közölt eredmény); $\operatorname{prod}^{U}$ egy EMS-indukált allél, melyben egy deletált guanin okozta frameshift mutáció stop kodont eredményez a 94. aminosav után. A prod109 a P\{lacW\}prod ${ }^{k 08810} / C y O$ homozigóta életképes revertánsa, melyet $\Delta 2$-3-mediált $\mathrm{P}$ elem kiugratással hoztak létre és a $P\{l a c W\}$ okozta mini-white szemszín fenotípus elvesztése alapján azonosítottak (Török, nem közölt eredmény). A prod ${ }^{E}$ egy hypomorf allél (glicin-glutaminsav csere a 61. aminosavban), lárva-báb letális, normális diszkuszokkal és melanizáció nélkül, valamint - ellentétben a null mutánsokkal - homozigóta mozaikfoltokban nem sejtletális. A $D f(1)$ RT876 terminális X kromoszóma deficiencia, amit 2006-ban hoztak létre a yellow génben, mu2 háttéren James Mason laboratóriumában a korábban leírtak alapján (Mason és mtsai., 1984); a $D f(2) l(2) g l^{G B 26} / C y$ ) terminális $2 \mathrm{~L}$ deficiencia korábban jellemzett (Walter és mtsai., 1995). Ezen terminális deléciókból hiányzik a TAS domén, valamint a terminális retrotranszpozonok (Biessmann és mtsai., 1990; Biessmann és Mason, 1988). Az smt $3^{04493}$ allél homozigóta letális, mert egy P elem inszerciót tartalmaz rögtön a transzkripciós start helye elött. A FlyBase adatbázis szerint a $l w r^{5}$ gyenge hypomorf, a $l w r^{05486}$ null és a $p z g^{1.3}$ null mutáns. A chro ${ }^{4 K G 12 A}$ egy pontatlan P-elem kivágódás eredménye, mely a kódoló régió nagy részét eltávolította (Gortchakov és mtsai., 2005). A $J I L-1^{3}$ egy funkciónyeréses mutáció, míg a $J I L-1^{z 2}$ egy funkcióvesztéses null allél (Zhang és mtsai., 2006). A Tel törzset (Siriaco és mtsai., 2002) James Mason biztosította számunkra. Az $E(t c)$ egy domináns allél, amely gyakoribb génkonverzió miatt hosszabb telomert eredményez (Melnikova és Georgiev, 2002). 


\section{Kromoszóma immunfestések}

Harmadik stádiumú ecetmuslica lárva nyálmirigyeit 45\%-os ecetsavban boncoltuk és fixáltuk tárgylemezen. A lemezeket 1 órán át blokkoltuk 2\% BSA, 2\% sovány tejpor és $0,2 \%$ Tween PBS oldatában. Az elsődleges ellenanyagot megfelelő arányban hígítottuk a fenti blokkoló oldatban és ebben 1 órán keresztül inkubáltuk a kromoszómákat szobahőmérsékleten. A tárgylemezeket kétszer mostuk 15 percig $300 \mathrm{mM} \mathrm{NaCl-t}$ és $0,2 \%$ Tween-t tartalmazó 1xPBS mosó oldatban. Ezután a lemezeket PBS-ben öblítettük, majd 30 perc blokkolás után blokkoló oldatban hígított másodlagos ellenanyagot adtunk hozzá. Egy óra elteltével a lemezeket PBS-ben, majd $100 \mathrm{mM}$ Tris $(\mathrm{pH}=7,5)$ oldatban öblítettük és 1 percig festettük PBS-ben oldott $1 \mu \mathrm{g} / \mathrm{ml}$ DAPI-val. Újabb PBS-ben való öblítés után n-propylgallátot tartalmazó 45\%-os glicerinnel fedtük le a tárgylemezeket, majd fluoreszcens mikroszkóppal vizsgáltuk azokat. A felhasznált ellenanyagok és hígításaik: tisztított nyúl-antiProd ellenanyag (Török és mtsai., 1997) - 1:1000; nyúl-anti-Chro (Gortchakov és mtsai., 2005) - 1:1000; egér-anti-Z4 monoklonális (Saumweber és mtsai., 1980) - 1:2; nyúl-anti-Smt3 (Muller és mtsai., 2000) Dr. Jacob Seeler-től - 1:50; nyúl-anti-DREF (Papai és mtsai., 2005) Boros Imrétől - 1:500. A megfelelő Alexa Fluor 488- és 546-konjugált másodlagos ellenanyagokat (Molecular Probes, Invitrogen) 1:500 hígításban használtuk.

\section{UV keresztkötés, formaldehid keresztkötés és kromatin tisztítás}

Az UV keresztkötés és a kromatin tisztítás 0-16 órás embriókon lett végrehajtva a Biggin által leírtak szerint 5x10 perc UV kezeléssel (Biggin, 1999). Az embriók legyüjtését, mosását és dekorionizálását az UV kezelés követte. Ez után a homogenizálás és a sejtmagok tisztítása következett NIB (nuclear isolation buffer) pufferben (0,3 M szukróz, $15 \mathrm{mM}$ Tris $\mathrm{pH}=7,5,15 \mathrm{mM} \mathrm{NaCl}, 60 \mathrm{mM} \mathrm{KCl}, 5 \mathrm{mM} \mathrm{MgCl} 2,0,1 \mathrm{mM}$ EDTA pH=8,0, 0,1 mM EGTA, 0,5 mM DTT, $1 \mathrm{mM}$ PMSF). A tisztított sejtmagok feltárása (lízis puffer: $10 \mathrm{mM}$ Tris pH=8,0, 100 mM NaCl, 1 mM EDTA pH=8,0, 0,1 \% NP-40, 1 mM PMSF) után szonikálás és $\mathrm{CsCl}$ grádiensen való tisztítás történt. A formaldehid keresztkötést Orlando és mtsai. által leírtak alapján végeztük (Orlando és mtsai., 1997). A tisztított embriókat fixáló puffer (2\% paraformaldehid, $50 \mathrm{mM}$ HEPES, $\mathrm{pH}=7,6,100 \mathrm{mM} \mathrm{NaCl}$, 0,1 mM EDTA, 0,5 mM EGTA) és heptán keverékében 15 percig forgatva fixáltuk, majd szonikáltuk és a kromatint tovább tisztítottuk $\mathrm{CsCl}$ grádiensben való centifugálással. A keresztkötött kromatint mindkét esetben 
átlagosan 750 bp nagyságú darabokra szonikáltuk, majd anti-Prod ellenanyaggal immunprecipitáltuk és a kinyert, Prod-hoz kötődő DNS frakciót proteináz K kezeléssel fehérjementesítettük és ${ }^{32} \mathrm{P}$ izotóppal jelöltük (Biggin, 1999).

\section{GST-pulldown}

A GST-Prod fúziós fehérjét a Török és mtsai. korábbi közleményében leírtak szerint tisztítottuk (Török és mtsai., 1997). A kötési reakció $400 \mu$ g-nyi 500 bp átlagos nagyságú szonikált Oregon-R DNS-t, $5 \mu$ g GST-Sepharose gyöngyökhöz (Pharmacia) kötött GST-Prod fehérjét, $0,1 \mathrm{mM}$ chemostatint, $170 \mathrm{mM} \mathrm{NaCl-t}, 20 \mathrm{mM}$ Tris (pH=8,0)-t, $1 \mathrm{mM}$ EDTA-t, 1 mM DTT-t és 5\% glicerint tartalmazott 1 ml-ben. A kötés $37{ }^{\circ} \mathrm{C}$-on zajlott 2 órán át. A Sepharose komplex centrifugálását 5 perces kötőpufferrel $(170 \mathrm{mM} \mathrm{NaCl}, 20 \mathrm{mM}$ Tris $\mathrm{pH}=8,0,1 \mathrm{mM}$ EDTA, $1 \mathrm{mM}$ DTT, 5\% glicerin és $0,1 \mathrm{mM}$ chemostatin) való mosás követte hatszor. Ezután a fenol-kloroformos extrakcióval visszanyert DNS-t etanollal csaptuk ki lineáris poliakrilamidot használva carrier-ként. A DNS-t ${ }^{32} \mathrm{P}$ izotóppal jelöltük random priming módszerrel a hibridizációhoz.

\section{BAC filterek és Southern blot hibridizáció}

Az RPCI-98 Drosophila melanogaster BAC könyvtárat (Hoskins és mtsai., 2000) tartalmazó filtereket a BACPAC Resources Center-től (http://bacpac.chori.org) szereztük be. Ez a könyvtár 18432 BAC klónt tartalmaz, mely 22-szer lefedi az egész Drosophila genomot. A Southern blot-ot Maniatis és mtsai. által leírtak alapján végeztük (Maniatis és mtsai., 1982). A hibridizálás “Church” pufferben (1 mM EDTA, 0,5 M Na-foszfát puffer, 7\% SDS), a mosás 1 mM EDTA, 40 mM Na-foszfát puffer, 1\% SDS oldatban történt.

\section{A HeT-A, 2L TAS, jockey és $1,686 \mathrm{~g} / \mathrm{ml}$ szatellita DNS fragmentumai}

$\mathrm{Az}$ 1. fragmentum a HeT-A 9D4 nevü klónból EcoRI enzimmel kivágott $5 \mathrm{~kb}$ nagyságú szakasz (Biessmann és mtsai., 1992a). Ez tartalmazza az 5' végi UTR szakaszt, de hiányzik belőle az utolsó $1 \mathrm{~kb}$ a 3' végi UTR szakaszból, beleértve az oligo(A) véget 
(részleges szekvenciája a GenBank X68130 szám alatt). A 2. és 3. fragmentum együtt lefedi a HeT-A elem RT 473 szakaszának az egész 2,4 kb hosszú 3'UTR részét (Biessmann és mtsai., 1992b) (GenBank M84200). Ez a szakasz két részre vágva adja az 1,9 kb hosszú HindIIIBamHI fragmentumot (2. fragmentum) és a 0,5 kb hosszú BamHI-BamHI fragmentumot (3. fragmentum). A 4., 5. és 6. szakaszok a 2. fragmentum szub-fragmentumai. A 4. egy 0,45 kb hosszú HindIII-PstI fragmentum, az 5. egy 0,9 kb hosszú PstI-PstI fragmentum, a 6. pedig egy 0,45 kb hosszú PstI-BamHI fragmentum. A 165 bp hosszú, szintén a 2. fragmentumból levágott PstI szakaszt nem tüntettük fel a szub-fragmentumok közt. Az összes fragmentumot pBluescript vektorba klónoztuk. A 461 bp nagyságú 2L TAS ismétlődés szekvenciájának (Walter és mtsai., 1995) GenBank azonosítója U35404. Az 5 kb méretü jockey transzpozon fragmentum a GAG ORF cink-ujjának BamHI helyétől az elem végéig tart (GenBank M22874), amit Gary Karpen bocsátott a rendelkezésünkre. Az 1,686 g/ml 10 bp szatellita 12 ismétlődését EcoRI-HindIII fragmentumként tartalmazó pBR322 klónt Alan Lohe biztosította számunkra (Lohe és Brutlag, 1986).

\section{RNS kivonás petefészekből és DNS kivonás a légy többi szövetéből}

A HeT-A transzkripció szintje magas az ováriumokban (Walter és Biessmann, 2004), ezért 30 nőstény petefészkét boncoltuk fel, melyből az össz RNS-t $700 \mu 1$ TRIzol Reagenssel (Gibco BRL Life Technologies, Rockville, MD) vontuk ki, majd izopropanollal kicsaptuk. A kinyert, átlagosan $60 \mu \mathrm{g}$ RNS-t $50 \mu \mathrm{l}$ vízben oldottuk fel. A DNS-t ugyanazon nőstények maradék szöveteiből vontuk ki, melyekből a petefészkeket boncoltuk. A DNS kivonást jégen végeztük $500 \mu 1$ homogenizáló pufferben, melynek tartalma 16,6\% szukróz, 2 mM EDTA, 0,5 mM EGTA, $60 \mathrm{mM} \mathrm{KCl,} 15 \mathrm{mM} \mathrm{NaCl}, 1,5 \mathrm{mM}$ spermin, $0,5 \mathrm{mM}$ spermidin és $15 \mathrm{mM}$ Tris$\mathrm{HCl}(\mathrm{pH}=7,4)$. Az oldatokat 2 percig fugáltuk $4{ }^{\circ} \mathrm{C}$-on, majd a felülúszót eltávolítottuk. A csapadékot $500 \mu 1$ lízis pufferben (0,1 M EDTA, 0,01 M Tris- $\mathrm{HCl}, \mathrm{pH}=7,4,0,02 \mathrm{M} \mathrm{NaCl}, 10$ $\mathrm{mg} / \mathrm{ml}$ szarkozil) oldottuk. $25 \mu$ proteináz $\mathrm{K}(20 \mathrm{mg} / \mathrm{ml})$ hozzáadása után 1 órát inkubáltuk $50{ }^{\circ} \mathrm{C}$-on, majd fenol/kloroformmal és kloroformmal extraháltuk. A DNS-t izopropanollal kicsaptuk, lecentrifugáltuk, majd a csapadékot vízben feloldva újra kicsaptuk 2,5 térfogatnyi etanollal. A DNS-t TE pufferben oldottuk fel. 


\section{cDNS szintézis}

A petefészekből nyert RNS-ből $3 \mu$ g-ot cDNS-sé írtunk át $10 \mu 1$-es reakciókban, mely 0,25 $\mu$ g oligo dT primert, 0,5 mM dNTP-ket, $10 \mathrm{mM}$ DTT-t, first strand szintézis puffert és 70 U SuperscriptII reverz transzkriptázt (Invitrogen, Carlsbad, CA) tartalmazott 5 percig 65 ${ }^{\circ} \mathrm{C}$-on enzim nélkül, majd 5 órán át $42{ }^{\circ} \mathrm{C}$-on enzimmel inkubálva. A reakciókat $70{ }^{\circ} \mathrm{C}$-on 15 perces inkubációval állítottuk le.

\section{Kvantitatív Real-Time PCR (qPCR)}

A kvantitatív PCR elvégzéséhez BioRad iCycler iQ ${ }^{\mathrm{TM}}$ Real-Time PCR gépet (BioRad, Hercules, CA) és SYBR Green detekciós reagenst használtunk. A reakciókat 96 lyukú mikrotitrátor lemezben végeztük $20 \mu 1$ térfogatban, amely $10 \mu 1$ iQ SYBR Green Supermix-et (BioRad, Hercules, CA), valamint 10-40 ng cDNS-t vagy genomikus DNS-t és mindegyik primerből $200 \mathrm{nM}$-t tartalmazott. A qPCR reakciók a következő programon futottak: 5 perc $95^{\circ} \mathrm{C}$-on, majd 40 ciklus 10 másodperc $95^{\circ} \mathrm{C}$-on és 45 másodperc $50{ }^{\circ} \mathrm{C}$-on.

$\mathrm{Az}$ olvadási görbe analízisét minden reakció végén elvégeztük, így biztosítva az amplifikált termék minőségét. Minden mikrotiter lemezből mindegyik primer-párra egy-egy kontroll görbét készítettünk és mindegyik reakciót legalább 3-szor megismételtük. Az így kapott értékeket átlagoltuk és az S17 riboszómális fehérje (RpS17) transzkriptumának koncentrációjára vagy a genomikus kópiaszámra normalizáltuk minden egyes reakcióban.

59-62 ${ }^{\circ} \mathrm{C}$ olvadáspontú specifikus primereket (Sigma-Proligo., Boulder, CO) terveztünk a HeT-A, a jockey elemekre, valamint a RpS17-re. A primerek használhatóságát számítógépen ellenőriztük BlastN program segítségével, majd egyszerü PCR reakciókkal genomikus DNS-ről ellenőriztük a primerek müködését, ahol a várt méretű fragmentumokat adták (195 bp az RpS17-ről, 152 bp a HeT-9D4GAG-ORF-ről és 124 bp a Jockey-GAG-RTjunc-ról). A primerek tervezéséhez felhasznált szekvenciák GenBank azonosító számai: a HeT-A 9D4 elemnek X68130, a jockey-nak M22874, az RpS17-nek pedig M22142.

Primerek:

RpS17-F:

5' AAGCGCATCTGCGAGGAG 3'

RpS17-R:

5' CCTCCTCCTGCAACTTGATG 3'

HeT-9D4GAG-ORF-F: 5' TTGTCTTCTCCTCCGTCCACC 3' 
HeT-9D4GAG-ORF-R: 5' GAGCTGAGATTTTTCTCTATGCTACTG 3'

Jockey-GAG-RT-junc-F: [' ACGACTCAATCTAGGGCTCGTG 3'

Jockey-GAG-RT-junc-R: 5' CGTCCATTCTCGTATTGATGG 3'

A kvantitatív PCR kísérleteket és az ahhoz közvetlenül kapcsolódó munkákat (RNS és DNS kivonás, stb.) az együttmüködő Harald Biessmann, valamint James M. Mason laboratóriuma végezte, a többi kísérleti eredmény a saját munkánkon alapszik.

\section{Élesztő két-hibrid kísérlet}

Az kísérlethez L40 élesztő törzset (genotípusa: MATa his34200 trp1-901 leu2-3,112 ade2 LYS2::(lexAop)4-HIS3 URA3::(lexAop)8-lacZ GAL4) használtunk.

Csali vektorként a pBTM116 vektort alkalmaztuk, mely a Prod fehérje teljes hosszúságú cDNS-ét tartalmazta. A Prod cDNS-t az eredeti klónból a következő primerekkel amplifikáltuk: fwd.: A GAA TTC CGG ATG AAC GGC AAG ATG; rev.: TC TGC AGT GGG ACA CTA TAA GGA CGG C. A primerekre tervezett hasítóhelyek segítségével a cDNS-t a csali vektor EcoRI-PstI helyére klónoztuk a megfelelő leolvasási keretben.

Csukaként a Clontech Matchmaker cDNS-könyvtárát (Cat. no: IL4003AH) használtuk a gyártó utasításai szerint. A Matchmaker könyvtár pACT2 vektort használ csuka vektorként, melynek XhoI-EcoRI helyére egy Drosophila melanogaster embrió cDNS könyvtárat

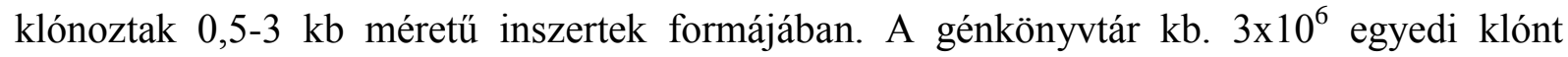
tartalmaz.

A klónozott csali és könyvtár cDNS-t tartalmazó csuka plazmidokat élesztőbe transzformáltuk. Első lépésben a Prod fehérje cDNS-ét tartalmazó csali vektort transzformáltuk be, és önaktivációs próbával ellenőriztük, hogy a Prod fehérje önmagában nem müködik-e aktivációs doménként. A negatív eredmény azt jelentette, hogy a csali vektorunk müködőképes a használt rendszerben, mert csak a könyvtár vektorral bevitt aktivációs domén jelenlétében képes bekapcsolni a riporter géneket.

A Prod csalit tartalmazó élesztő törzsből kompetens sejtet készítettünk, majd betranszformáltuk a cDNS könyvtárat tartalmazó plazmidokat is, és megfelelő szelekciót biztosító táptalaj lemezekre szélesztettük. 
A táptalajon kinövő kolóniák fehérje kölcsönhatásra utalnak, amit $\beta$-galaktozidáz festés többszöri átoltás utáni megismétlésével erösítettünk meg, kizárva a gyenge háttér kölcsönhatásokat.

A $\beta$-galaktozidáz tesztben pozitív élesztő kolóniákból plazmid DNS-t vontunk ki, majd a kinyert plazmidokat baktérium kompetens sejtbe transzformáltuk.

A felnövekvő baktérium telepekből kolónia hibridizációval választottuk ki a pACT2 vektort, így a cDNS könyvtár szakaszt is tartalmazó klónokat. Ezekből plazmidot tisztítottunk és inszertjeiket szekvenáltattuk. A kísérlet során kb. 120000 cDNS klónt vizsgáltunk át, és végül a legígéretesebb 100 Prod-kölcsönható fehérje klónját szekvenáltattuk meg.

\section{Immunprecipitáció}

A kísérletet S2 sejteken végeztük. $10^{7}$ sejtet fugálással ülepítettünk (6000 rpm, 1 perc), majd egy 1xPBS mosás után felszuszpendáltuk $1 \mathrm{ml}$ lízis pufferben $(50 \mathrm{mM}$ Tris, pH=7,5, 50 $\mathrm{mM} \mathrm{NaCl}, 0,2 \%$ NP-40, 0,5 mM EDTA, 1 mM PMSF, Roche Complete Mini Protease Inhibitor, $1 \mathrm{mM}$ DTT). Jégen inkubáltuk 1 órát, majd a lizátumot $4{ }^{\circ} \mathrm{C}$-on centrifugáltuk (2 perc, $10000 \mathrm{rpm})$. A felülúszót tovább centrifugáltuk (10 perc, $13000 \mathrm{rpm})$ és a felülúszóval dolgoztunk tovább. Előtisztításként a lizátumhoz $25 \mu$ l lízis pufferrel telített Protein ASepharose-t adtunk és 1 órán át rázattuk $4{ }^{\circ} \mathrm{C}$-on. Ülepítés után (1 perc, $\left.2000 \mathrm{rpm}\right) \mathrm{a}$ Sepharose gyöngyöket 3x mostuk lízis pufferben, majd 1xLaemmli pufferben vettük fel és a Kontroll sávban futtatuk, a felülúszóból pedig immunprecipitálást végeztünk. Prekomplexet készítettünk $50 \mu 1$ térfogat Protein A-Sepharose és $6 \mu 1$ anti-Prod ellenanyag (ill. $10 \mu 1$ antiChro ellenanyag) inkubálásával $1 \mathrm{ml}$ lízis pufferben 1 óráig $4{ }^{\circ} \mathrm{C}$-on. Ezt $3 \times 5$ percig mostuk lízis pufferben. A prekomplex egyik fele kontrollként futott az $\mathrm{AB}$ sávban, a másik feléhez pedig hozzáadtuk az előtisztított lizátumot és éjszakán át inkubáltuk $4{ }^{\circ} \mathrm{C}$-on. Másnap centrifugáltuk (1 perc, $2000 \mathrm{rpm}$ ) és a felülúszó 1/50 részét is megfuttatuk, hogy az immunprecipitáció hatékonyságát ellenőrizzük. A Sepharose gyöngyöket 3x5 percig mostuk lízis pufferben, majd felvettük $40 \mu 1$ 1xLaemmli mintapufferben és megfuttatuk SDS gélen. 


\section{EREDMÉNYEK}

\section{A Prod fehérje eukromatikus szerepének vizsgálata}

Először azt feltételeztük, hogy az eukromatikus jelenlét is közvetlen DNS kötésen keresztül érvényesül, ezért az eukromatikus funkció kiderítésére elsőként Prod-hoz kötődő eukromatikus DNS szakaszokat próbáltunk azonosítani. Ehhez elöször tisztított, szonikált Drosophila genomikus DNS-ből halásztuk ki a tisztított Prod fehérjéhez kötődő DNS szakaszokat (8. ábra), később in vivo DNS-fehérje keresztkötést (UV sugárzással vagy formaldehiddel = FA) követően Prod-hoz kötődő DNS szakaszokat izoláltunk immunprecipitálással, majd a Prod-kötő szekvenciákat rendezett BAC könyvtárhoz hibridizáltuk, hogy azokat pontosan azonosíthassuk. Ezzel a módszerrel 274 klónt azonosítottunk a filteren található 18432 BAC klónból, de ezek egyike sem felelt meg a muslica eukromatikus szekvenciáknak, hanem heterokromatikus, transzpozon és szennyeződésből származó szekvenciáknak bizonyultak. Ezen kísérlet kudarca arra utalt, hogy az eukromatikus kötés minden bizonnyal elsősorban nem DNS, hanem fehérje kölcsönhatások útján érvényesülhet.
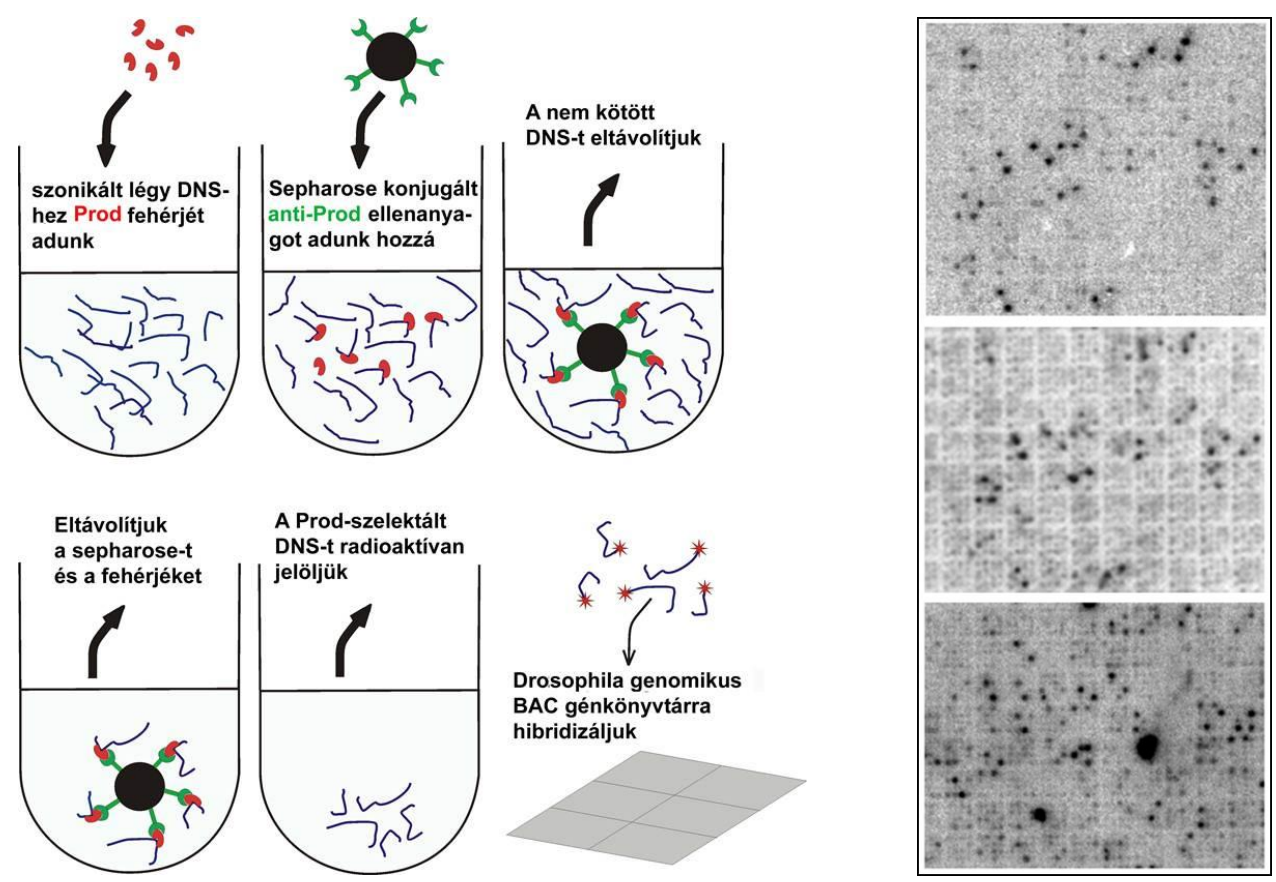

Sejtmagi

extrakt

UV-keresztkötés

FA-keresztkötés 
8. ábra. Az eukromatikus funkció kiderítésére irányuló kísérlet folyamatábrája (balra) és a hibridizált BAC filterek előhívott képe (jobbra). Ábramagyarázatot lásd a szövegben.

\section{A Prod fehérje a telomerek HTT sorához kötődik}

Ecetmuslica lárva nyálmirigy politén kromoszómáinak immunfluoreszcens festése alapján a Prod fehérje számos eukromatikus helyen túl (Török és mtsai., 1997) egyértelmüen kijelöli az összes telomert (9. ábra). Először azt szándékoztuk tisztázni, hogy a telomerikus lokalizáció a három telomerikus domén közül melyikkel kapcsolatos.
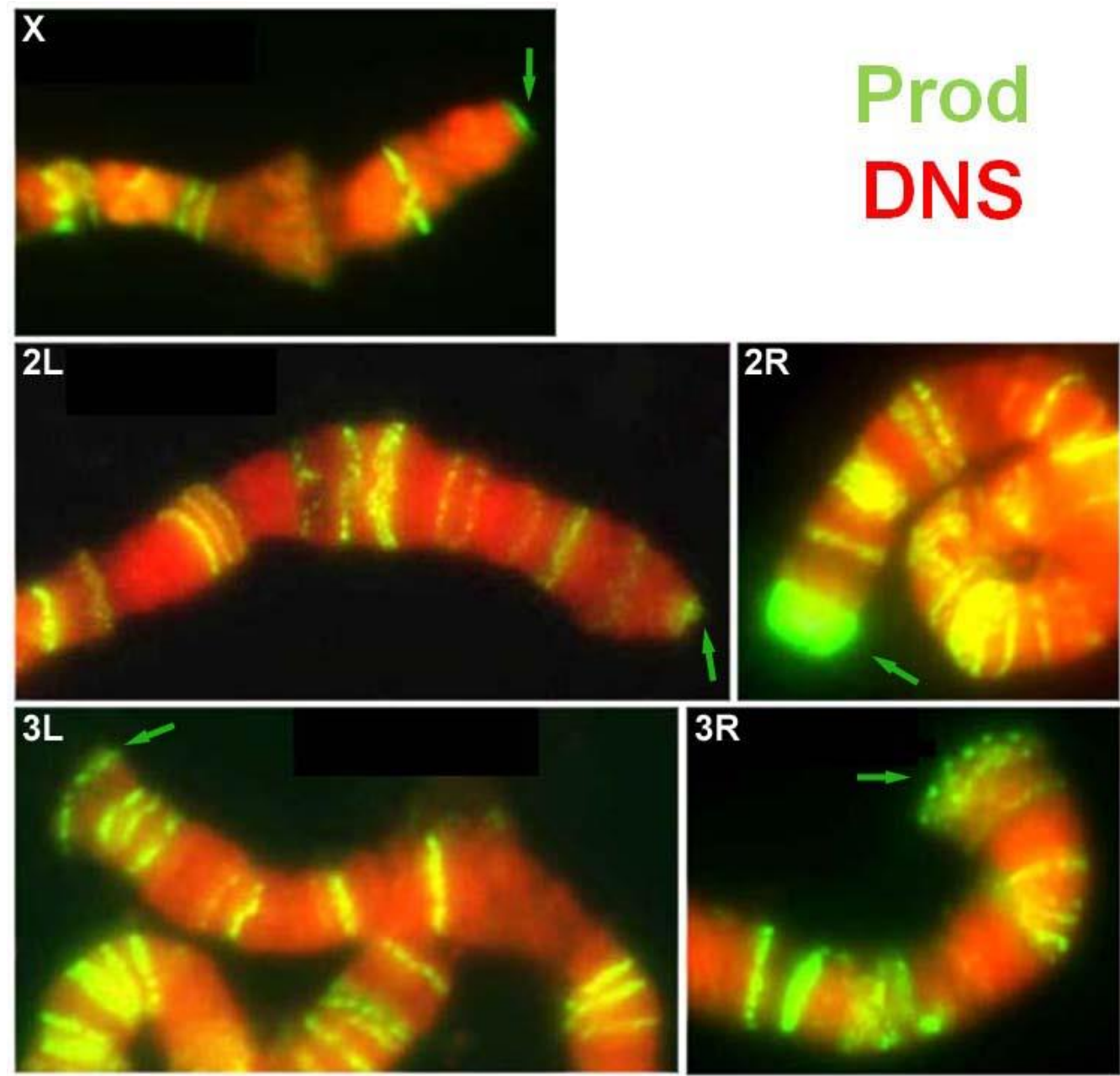

9. ábra. Prod fehérje immunlokalizációja ecetmuslica lárva nyálmirigyének politén óriáskromoszómáin. A képeken látható vad típusú (Oregon-R) kromoszómavégek mindegyike jellegzetes Prod festődést mutat (zöld nyilak). 
A telomerek Prod festődési mintázata emlékeztet a HeT-A próbákkal történt in situ hibridizáció képére, mely jellegzetesen pontszerű eloszlást mutat a 3R (harmadik kromoszóma jobb karja) és 3L (bal kar) telomereken (9.ábra). Ez a Prod-HeT-A kapcsolatra utaló jel azonban önmagában nem elég bizonyíték, és nem zárja ki a többi telomerikus szekvenciához való lehetséges kötődést.

Hogy megvizsgáljuk a Prod esetleges kötődését a TAS heterokromatinjához, megfestettük a yellow ${ }^{l}\left(y^{l}\right)$ törzs politén kromoszómáit. A $y^{l}$ mutáns allél egy olyan kisméretü deléció eredménye az X kromoszómán, amely a kromoszóma végén elhelyezkedő yellow gén mellett az X kromoszóma TAS doménjét is teljesen eltávolítja (Abad és mtsai., 2004a). Amint az a 11. B ábrán látható, a Prod fehérje jelen van ezeken a kromoszómavégeken is, tehát a TAS domén hiányában is kötődik a telomerekhez. Ez az adat nem zárja ki a TAS-hoz való kötődést, de arra utal, hogy a Prod elsődleges kötőhelye vagy a HTT doménen vagy a cap doménen található.

Ezután megvizsgáltuk a Prod fehérje jelenlétét a HTT kromatinon. Ehhez egy olyan domináns mutációt $($ Telomere elongation $=\mathrm{Tel}$ ) tartalmazó törzset használtunk, amely a vad típusnál mintegy tízszer hosszabb HTT doménnel rendelkezik (Siriaco és mtsai., 2002). A Tel törzs nagyméretü telomerhossza a megnövekedett $H e T$-A, TART és TAHRE példányszámnak köszönhető, közülük is kb. 90\%-ot a HeT-A retrotranszpozon tesz ki. Tel genotípusú legyeket keresztezve vad típusú, rövidebb telomerekkel rendelkező Oregon-R törzzsel olyan heterozigótát hoztunk létre, melynek óriáskromoszómáin a hosszú HTT-t hordozó Tel homológ jóval túlnyúlik a másik, rövidebb Oregon-R homológ végén (10. ábra).

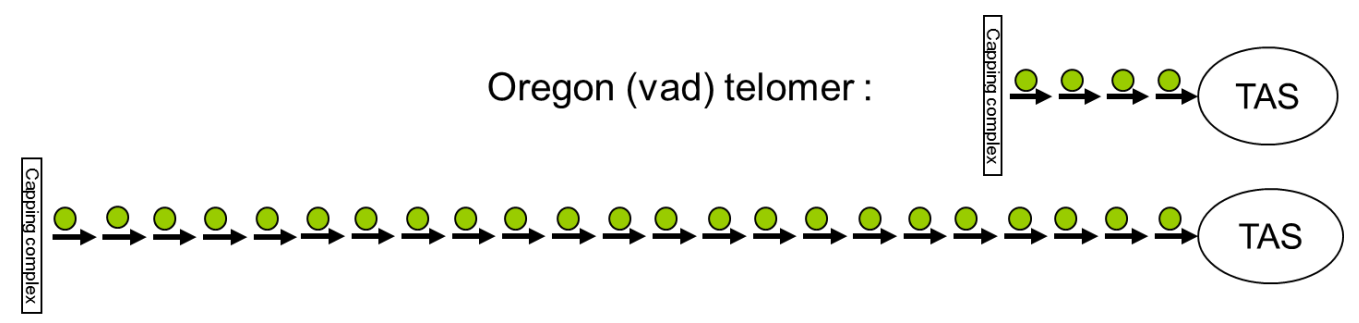

Tel mutáns telomer : 10x hosszabb retrotranszpozon sor

10. ábra. Oregon-R/Tel heterozigóta telomer szemléltető ábrája. Magyarázatot lásd a fenti szövegben. 
Ezen kromoszómákat anti-Prod ellenanyaggal megfestve a két homológ jól megkülönböztethető és a festődés a túlnyúló Tel homológ HTT sorának teljes hosszán látható, míg a jóval rövidebb Oregon-R HTT kevésbé jelölődik (11. ábra F,G). Ez az eredmény arra utal, hogy a Prod fehérje a HTT doménhez kapcsolódik. A cap alkotó HP1 fehérje a fenti Tel/Oregon kromoszómákon mindkét homológnak csupán a telomer csúcsára lokalizálódik, a HTT sor hosszára való tekintet nélkül (Siriaco és mtsai., 2002).

A Prod fehérje cap komplexből való hiányát jelezheti, hogy a prod mutánsokban nem találunk anafázis hidakat (Török és mtsai., 1997), ami cap fehérjét kódoló gének jellegzetes mutáns fenotípusa. Azt, hogy a Prod nem része a capping komplexnek, egy további kísérlettel igazoltuk: két terminális deléciót hordozó törzs telomerein vizsgáltuk a fehérje jelenlétét. Az egyik ilyen törzs a 2L terminális deficienciát hordozó $l(2) g l^{G B 26}$, a másik pedig a $D f(1) R T 867$, amelyik egy újonnan indukált X kromoszómás terminális deléció. Mindkét deficiencia eltávolítja a terminális retrotranszpozonokat és a TAS-t is, azonban a cap komplex jelen van mindkét deletált kromoszóma végén. A terminálisan deletált kromoszómák egyikén sem tudtuk kimutatni a Prod fehérje jelenlétét (11. ábra H, I), ami közvetlen bizonyíték arra, hogy a Prod fehérje nem része a terminális capping komplexnek. 

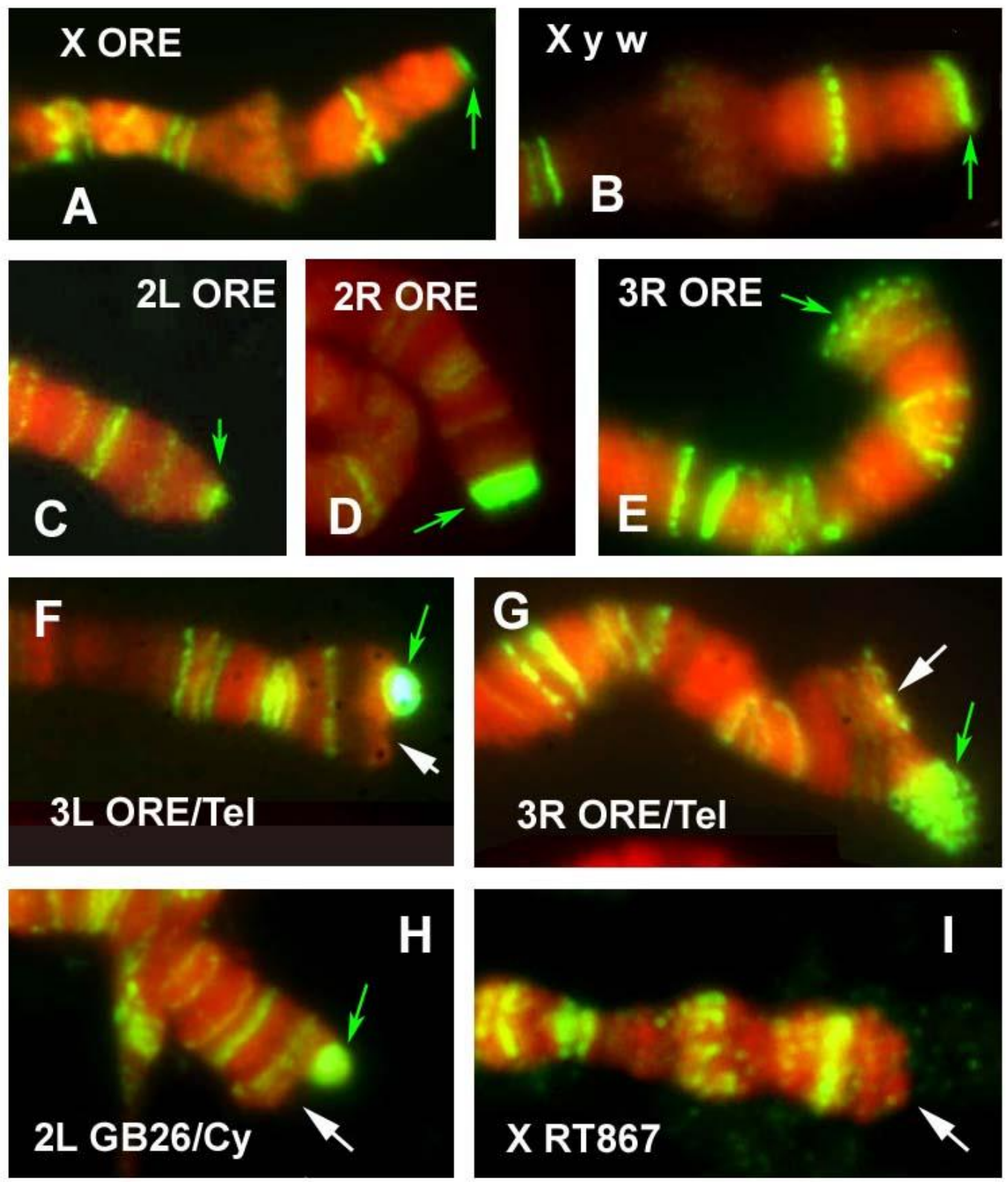

11. ábra. Különböző genotípusú politén kromoszómák Prod-festése. A képeken csak a kromoszómavégek láthatóak, amelyeken a zöld nyilak a Prod fehérje telomerikus lokalizációját jelzik. Az A képen TAS doménnel rendelkező Oregon-R (ORE) X kromoszóma, a $\mathrm{B}$ képen TAS-t nem tartalmazó $y^{l} w \mathrm{X}$ kromoszóma vége látható (Abad, 2004a). A Prod mindkét telomeren jelen van, tehát kötődésének nem feltétele a TAS jelenléte. (C-E) A Prod fehérje jelenléte a vad típusú 2L, 2R és 3R telomereken. $(\mathrm{F}, \mathrm{G})$ Prod lokalizáció a hibrid Oregon-R/Tel telomereken, ahol a meghosszabbodott HTT sorral rendelkező Tel homológ (zöld nyilak) jóval több Prod fehérjét köt, mint a rövidebb Oregon-R retrotranszpozon sor (fehér nyilak). (H, I) A TAS domént és a retrotranszpozon sort egyaránt eltávolító terminális kromoszóma deficienciák esetében 
megszünik a telomerikus Prod kötődés. A terminális $2 \mathrm{~L}$ deficiencia $l(2) g l^{G B 26} / C y$ esetében a Prod fehérje csak a balanszer kromoszóma telomerén van jelen (zöld nyíl), a megrövidült terminálisan deletált homológról hiányzik ( $\mathrm{H}$ - fehér nyíl). Hasonlóképpen nem látható telomerikus Prod festődés az $D f(1) R T 867$ terminális $\mathrm{X}$ kromoszómás deficiencia esetében sem (I - fehér nyíl).

\section{A Prod fehérje közvetlenül a $\mathrm{HeT}$-A elem promótere elé kötődik}

Ez után megvizsgáltuk, hogy a Prod-HTT kölcsönhatás közvetlen DNS-kötéssel valósul-e meg. A Prod fehérje és a $H e T-A$ szekvenciák kölcsönhatásának vizsgálatához két biokémiai megközelítést alkalmaztunk, a GST-pulldown-t és a kromatin immunprecipitációt (ChIP). Először a legyekböl kivont genomikus DNS-t szonikálással feldaraboltuk, majd tisztított GST-Prod fúziós fehérjével inkubáltuk, ezután pedig a Prod-DNS komplexeket glutathion-sepharose gyöngyökhöz való kötéssel (GST-pulldown) kitisztítottuk (8. ábra). Egy másik kísérletben, embriókban a kromoszómális fehérjéket in vivo fizikailag keresztkötöttük a DNS-hez UV besugárzással vagy formaldehiddel (FA), majd szonikálás után a Prod tartalmú kromatin fragmentumokat anti-Prod ellenanyaggal történő immunprecipitálással nyertük ki (UV-ChIP illetve FA-ChIP). Az így kinyert, Prod-hoz kötődő DNS frakciót mindkét esetben fehérjementesítettük és ${ }^{32} \mathrm{P}$ izotóppal jelöltük. Ezután a jelölt DNS-t Drosophila rendezett BAC génkönyvtárat tartalmazó filterre hibridizáltuk. A géntár 18432 BAC klónt tartalmaz, mely 22-szer fedi le a teljes genomot. A klónok 384 négyzetre vannak nyomtatva, mindegyik négyzet 2x8 BAC klónt tartalmaz egy 4x4-es rács mintában egyedi elrendezésben. A 12. ábrán a filter egy reprezentatív részletének autoradiogramja látható a hibridizálást követően. Megvizsgáltuk, hogy a HeT-A tartalmú BAC klónok mekkora hányada bizonyult pozitívnak a hibridizálás eredményeként. A HeT-A tartalmú klónokat HeT-A DNS hibridizációjával azonosítottuk (12. ábra, HeT-A filter). A hibridizálási mintázatok összehasonlítása azt mutatta, hogy a HeT-A szekvenciát tartalmazó BAC klónok az esetek túlnyomó többségében a Prodkötött DNS frakcióval is pozitív hibridizációs jelet adtak. 
UV
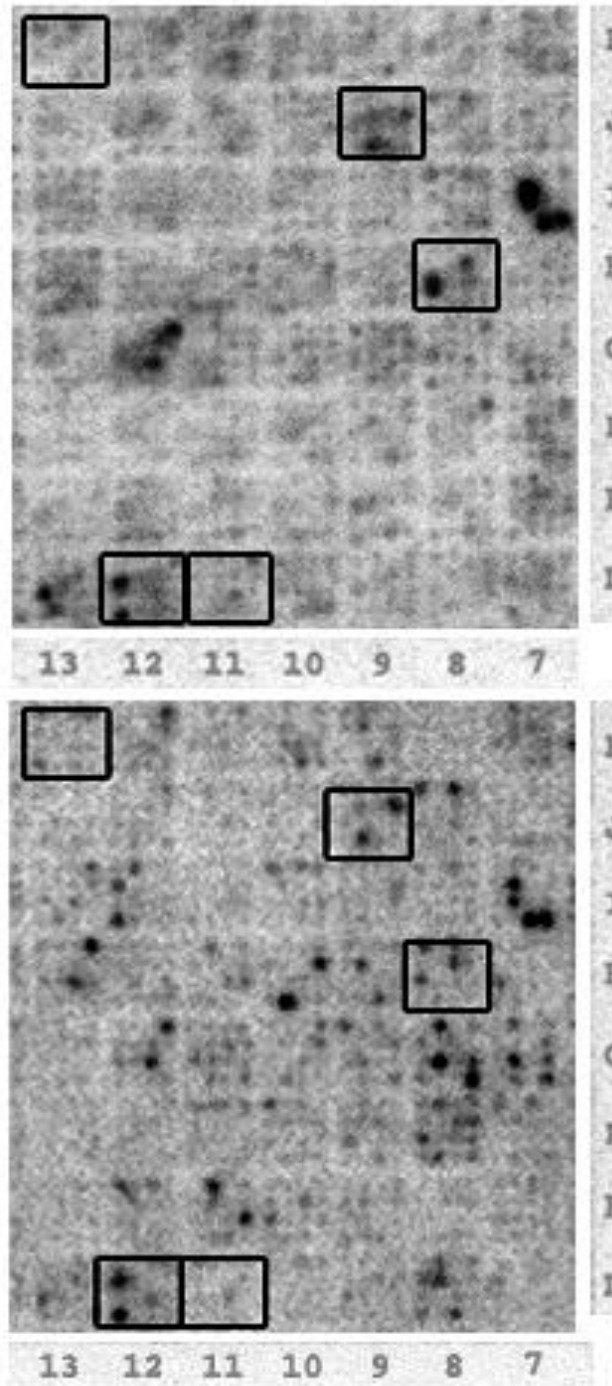

FA
HeT-A
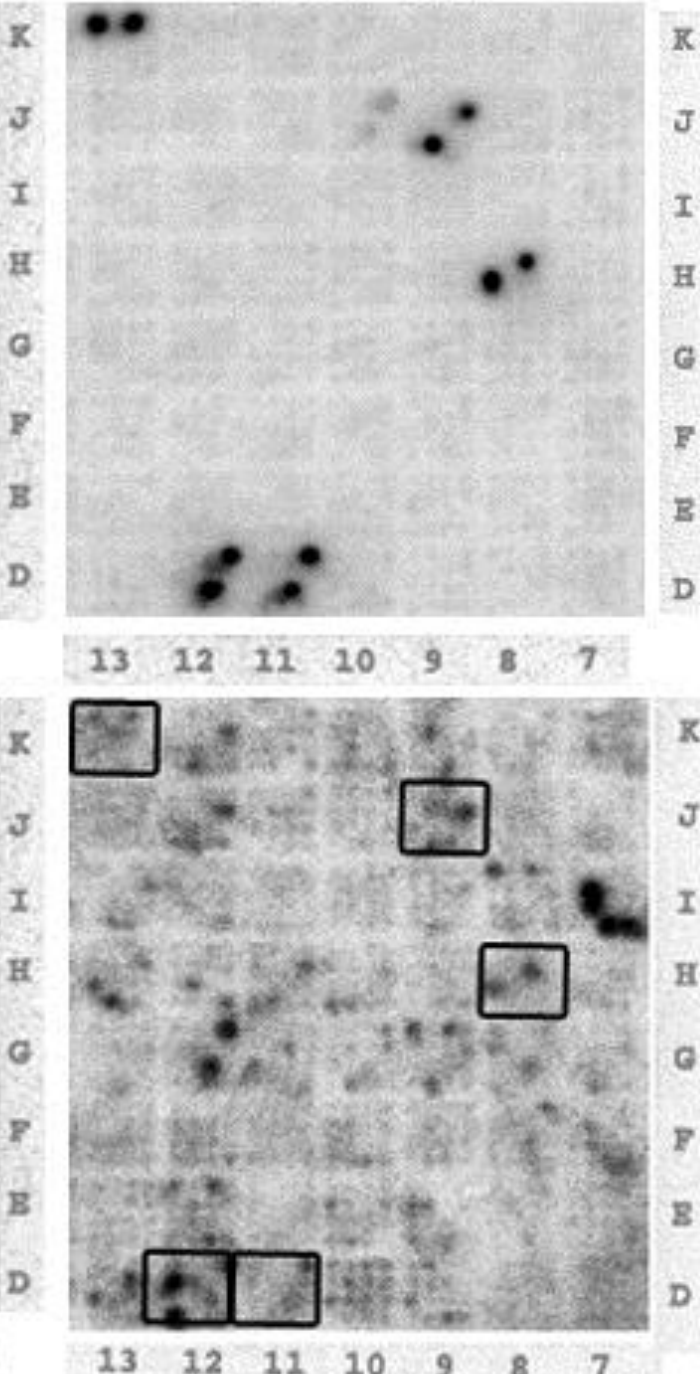

GST

12. ábra. Ugyanazon $B A C$ filter négy különböző próbával történő hibridizálásának autoradiográfiás képe. Az egyedi BAC klónok jellegzetes dupla pont mintázat alapján azonosíthatóak. A képek a filter azonos régiójáról készültek. A bekeretezett négyzetek mindegyik képen ugyanazokat a HeT-A tartalmú BAC klónokat jelölik. A BAC filterek különböző próbákkal lettek hibridizálva. HeT-A panel: HeT-A 9D4 elemének 5 kb-os szakasza; UV panel: UV-keresztkötött embrió kromatinból Prodimmunprecipitált és tisztított DNS; FA panel: formaldehid-keresztkötött embrió kromatinból Prod-immunprecipitált és tisztított DNS; GST panel: Oregon-R DNS-ből GST-Prod fúziós fehérjével kihúzott DNS. 
A hibridizáció számszerü eredményét az 1. táblázat foglalja össze. A HeT-A próbával történő hibridizálás 48 HeT-A tartalmú BAC klónt jelzett, melyeknek 82\%-a az UV-ChIP DNS frakciókkal, 79\%-a a GST-pulldown, 71\%-a pedig a FA-ChIP során kinyert DNS-sel szintén hibridizált. Ez az eredmény alátámasztja a kromoszómafestés megfigyeléseit és azt valószínüsíti, hogy a Prod közvetlenül kötődhet a $H e T-A$ DNS-hez, így része a $H e T-A$ tartalmú kromatinnak. Azonban a Prod-pozitív DNS frakció azon hibridizációs jelei, melyek a $H e T$-A-pozitív klónokra esnek kifejezetten gyengék a többi Prod-pozitív BAC klónnal összehasonlítva (az ábráról nem nyilvánvaló, de az egész filtert tekintve egyértelmüen megállapítható) és a korreláció sem 100\%-os. Ez arra utal, hogy a Prod viszonylag alacsony affinitással kötődhet a HeT-A DNS-hez.

\begin{tabular}{|c|c|c|c|c|}
\hline $\begin{array}{c}\text { HeT-A } \\
\text { pozitívak }\end{array}$ & $\begin{array}{c}\text { GST-Prod } \\
\text { pozitívak }\end{array}$ & $\begin{array}{c}\text { UV-Prod } \\
\text { pozitívak }\end{array}$ & $\begin{array}{c}\text { FA-Prod } \\
\text { pozitívak }\end{array}$ & $\begin{array}{c}\text { Százalékos } \\
\text { átfedés }\end{array}$ \\
\hline $\begin{array}{c}8 \\
\text { (nagyon erős) }\end{array}$ & 7 & 7 & 6 & $75-87$ \\
\hline $\begin{array}{c}6 \\
\text { (erős/közepes) }\end{array}$ & 4 & 4 & 3 & $50-66$ \\
\hline $\begin{array}{c}34 \\
\text { (gyenge) }\end{array}$ & 27 & 28 & 24 & $71-82$ \\
\hline $\begin{array}{c}48 \\
\text { (összes) }\end{array}$ & 38 & 39 & 33 & $69-81$ \\
\hline
\end{tabular}

1. táblázat. A 18432 Drosophila BAC klónt tartalmazó filterek hibridizálásának eredménye. Az 1. oszlopban a ${ }^{32} \mathrm{P}$-jelölt $H e T-A$ DNS fragmentummal való hibridizálás után pozitív BAC klónok száma (és erőssége) látható. A 2. oszlop a GST-Prodpulldown során kinyert DNS-sel is hibridizáló HeT-A-pozitív BAC klónokat jelzi. A 3. és 4. oszlopban az UV, ill. formaldehid keresztkötött embrionális kromatinból antiProd ellenanyaggal immunprecipitált DNS-sel szintén hibridizáló HeT-A-pozitív BAC klónok száma szerepel. A HeT-A próbával és mindhárom módon kinyert fehérje-DNS mintával való hibridizálás közti százalékos átfedést az 5. oszlop mutatja a HeT-Apozitív BAC klónok kategóriáira lebontva.

Hogy közvetlen bizonyítékot nyerjünk a Prod fehérje kötődésére a HeT-A DNS-hez és hogy a kötődés helyét is pontosítsuk, a $6 \mathrm{~kb}$ hosszú HeT-A retrotranszpozon különböző darabjait tartalmazó filterre hibridizáltuk az UV- és FA-keresztkötött embriókból Prod ellenanyaggal immunprecipitált, ${ }^{32} \mathrm{P}$-jelölt DNS-t (13. ábra). 

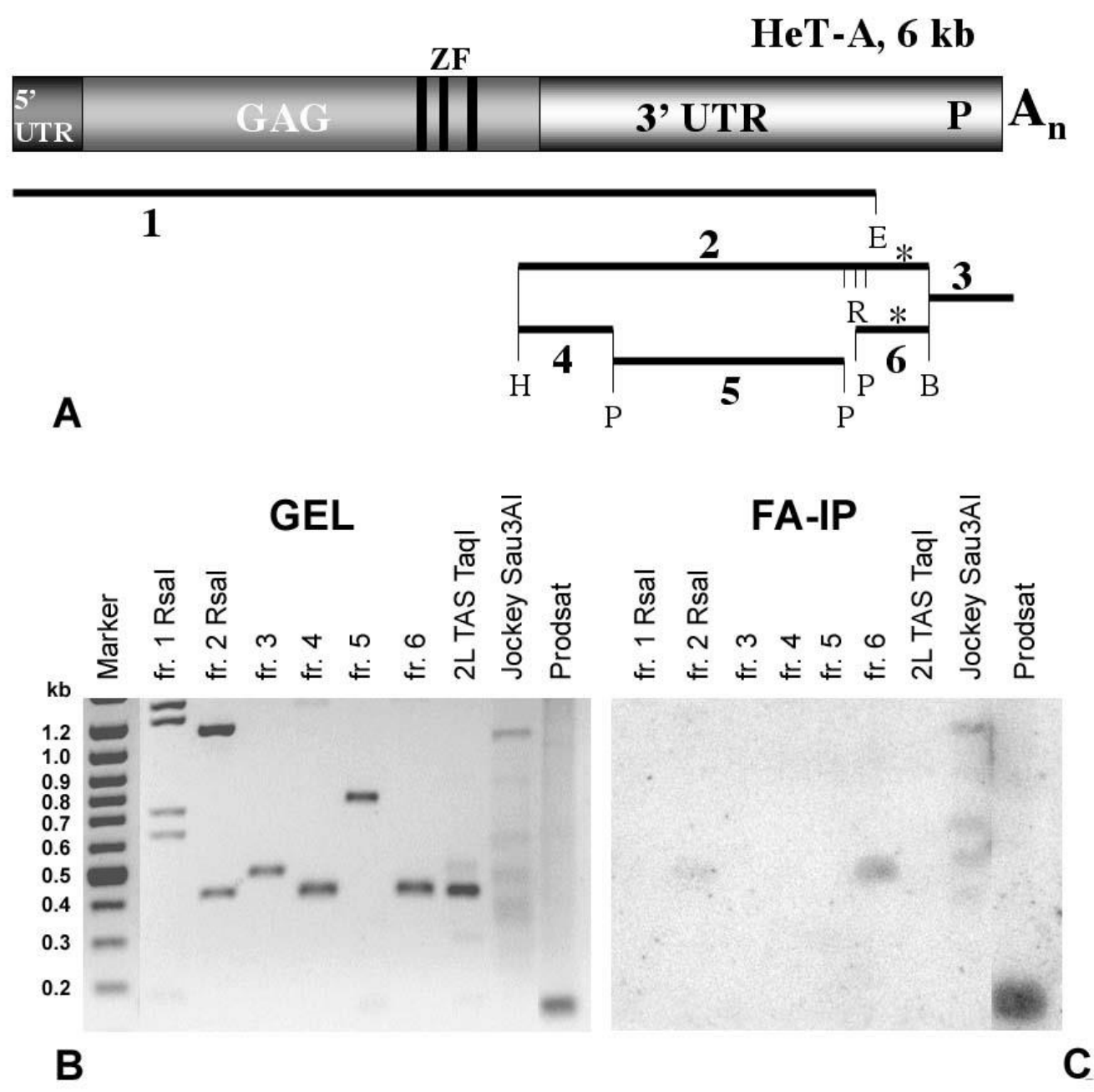

13. ábra. A Prod fehérje kötődése a HeT-A DNS-hez (A) A Southern blot hibridizációhoz használt HeT-A DNS fragmentumok. A fragmentumok restrikciós emésztéssel készültek: $\mathrm{B}=$ BamHI, R=RsaI, H=HindIII, E=EcoRI, $\mathrm{P}=$ Pst I. ZF = a három cink-ujj helye a GAG fehérjében. $\mathrm{P}=$ a promóter régió hozzávetőleges helye. $\mathrm{A}$ csillagok a $\mathrm{C}$ filteren pozitív hibridizációs jelet mutató 2. és 6 . fragmentumokat jelölik. (B) Az A ábrán jelölt HeT-A fragmentumok és kontrollként 2L TAS, jockey fragmentumok, valamint (pozitív kontrollként) ProdSat DNS fragmentum agaróz gélen futtatva és etídium-bromiddal festve. (C) A B képen látható gél Southern blotjának autoradiogramja. A hibridizálás FA-keresztkötött embrió kromatinból Prodimmunprecipitált és tisztított DNS-sel történt. 
A Southern blot autoradiogramja (13. ábra C) azt mutatja, hogy a legkisebb vizsgált Prod-kötő DNS fragmentum a 2. számú fragmentumból RsaI emésztéssel kapott 450 bp hosszú RsaI-BamHI fragmentum (13. ábra A) és az ezzel csaknem megegyező 6. számú 454 bp hosszúságú PstI-BamHI fragmentum (13. ábra A, csillagokkal jelölve). Ez a Prod-kötő fragmentum a HeT-A transzpozon oligo(A) végétöl upstream irányban 504 és 953 bp között található. Egyéb HeT-A fragmentumok nem adtak jelet, valamint szintén nem hibridizált a 2. kromoszóma bal karjának telomeréről származó 461 bp hosszú TAS ismétlődés sem, melyet negatív kontrollként használtunk. A HeT-A legközelebbi rokona, a jockey retrotranszpozon darabjai esetén (Biessmann és mtsai., 1992b) az FA-IP minta mutatott némi hibridizációt. Ahogy azt vártuk, a Prod-dal kihúzott DNS frakció erősen hibridizált az 1,686 g/ml 10 bp szatellita (ProdSat) szekvenciához, melyhez a Prod fehérje erősen és kooperatívan kötődik (Török és mtsai., 2000). Az UV keresztkötött fragmentumok ezzel megegyező eredményt adtak. Mivel az UV fény csak abban az esetben okoz DNS-fehérje keresztkötéseket, ha a fehérjék és a DNS között szoros közelség van (Biggin, 1999), a fenti eredmények arra utalnak, hogy a Prod in vivo közvetlenül kötödik a HeT-A DNS 6. fragmentumához. Ismert, hogy a HeT-A transzpozon promóter szekvenciája a 3’UTR szakasz utolsó 400-600 bázispárnyi szakaszára esik, mely durván megfelel a 13. ábrán látható 3. fragmentumnak (Danilevskaya és mtsai., 1997; Kahn és mtsai., 2000). Ennek megfelelően igen sajátos módon minden $H e T-A$ gén átírását a tőle disztálisan elhelyezkedő szomszédos elem promótere irányítja (Biessmann és mtsai., 1994). Az általunk azonosított Prod kötőhely közvetlenül a HeT-A promóter szomszédságában, attól upstream helyzetben található, amiből arra következtettünk, hogy a Prod esetleg szerepet játszhat a HeT-A transzkripció szabályozásában.

Egy további kísérletben megpróbáltuk a Prod-kötő szakaszt tovább szükíteni. Ehhez a 454 bp-nyi 6. számú DNS fragmentumot további restrikciós emésztésekkel még kisebb darabokra vágtuk, és a fenti Southern hibridizációt ezen szubfragmentumokkal is megismételtük. A 14. ábráról leolvasható, hogy a Prod egy kb. 200 bp hosszúságú AvaII-ApoI fragmentumhoz kapcsolódik. 

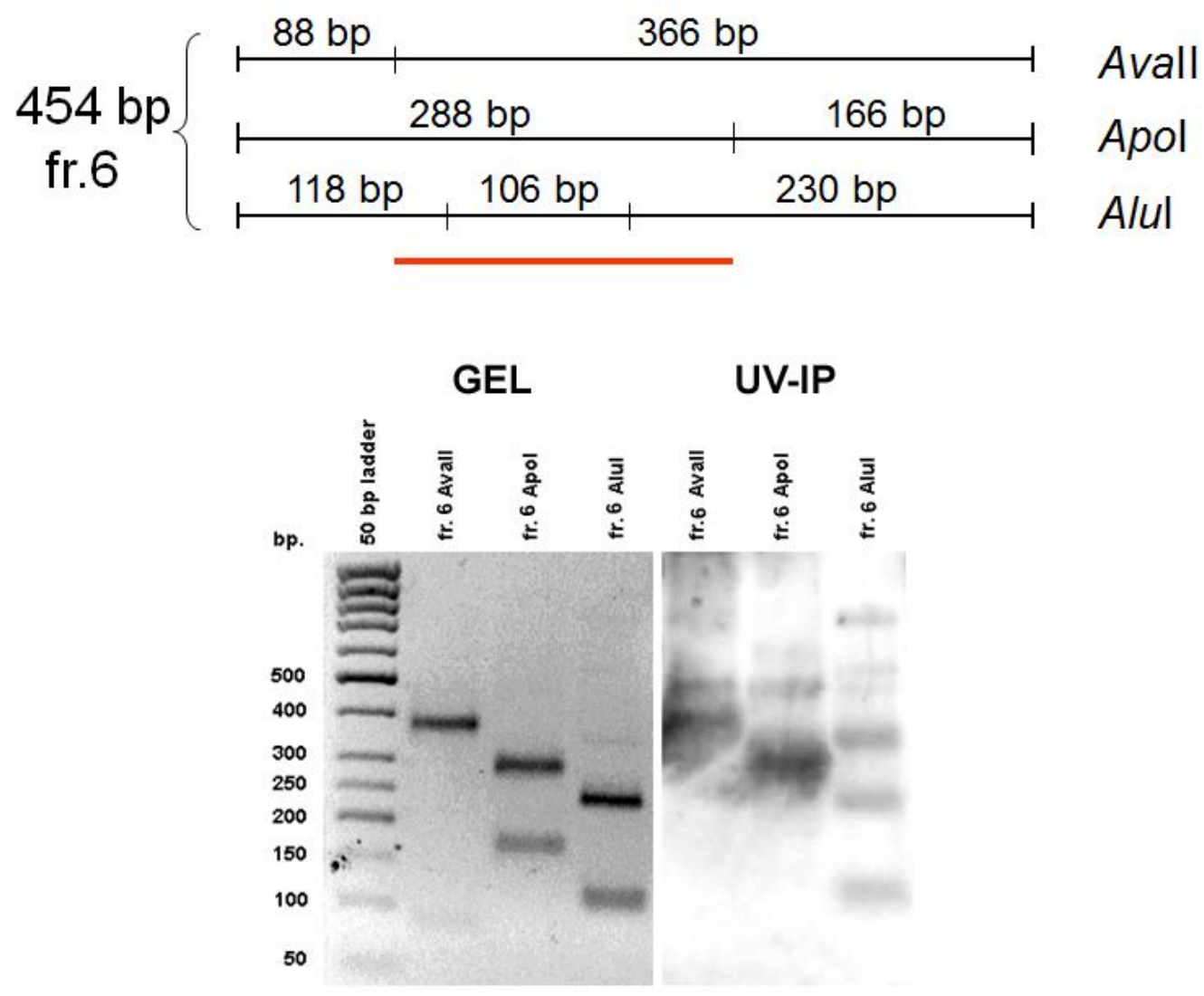

14. ábra: A Prod-kötő HeT-A fragmentum további pontosítása a 13. ábra 6. számú fragmentumának tovább darabolásával. A Southern blot (UV-IP) hibridizációs mintázatáról leolvasható, hogy a Prod a pirossal jelzett kb. 200 bp-nyi DNS szakaszhoz kapcsolódik.

\section{A Prod a $\mathrm{HeT}$ - $\mathrm{A}$ transzkripció represszora lehet}

A Prod a HeT-A transzkripció aktivátora, vagy represszora is lehet. Ha a Prod fehérje represszálja a HeT-A transzkripciót, akkor azt várnánk, hogy csökkent Prod dózis megnövekedett expressziót eredményez, ami megemelheti a transzpozíciók gyakoriságát és ezen keresztül a telomerek hosszát. Ezért elsőként arra voltunk kíváncsiak, hogy a HeT-A elem transzkripciós szintje megváltozhatott-e a $\operatorname{prod} / C y O$ heterozigótákban a vad típushoz képest, mivel ezen heterozigótákban elméletileg felére csökken a Prod dózis mennyisége a vad típushoz képest. 
Mivel a HTT transzpozonok transzkripciós aktivitása a petefészekben a legjelentősebb (Walter és Biessmann, 2004), ezért kvantitatív reverztranszkripciós-PCR-el (qRT PCR) meghatároztuk a $H e T-A$ transzkriptumok szintjét ebben a szövetben.

A HeT-A elemek nem egységesek, mert legalább 4 különböző alcsaládjukat (A-D) azonosították az izogenizált $y$; cn br sp törzsben (Abad és mtsai., 2004a), ezért az összes HeT$A$ elemet felismerő primer sorozatot nem tudtunk tervezni. Jelenleg nincs elérhető adat a különböző HeT-A alcsaládok viszonylagos arányáról az egyes légytörzsekben. Annak ellenére, hogy az egyes törzsekben a HeT-A összetétel különböző lehet, úgy gondoltuk, hogy egyetlen $H e T-A$ változat expressziós szintjének, valamint kópiaszámának változása is jól tükrözheti a teljes HTT domén aktivitását és méretét. Technikai okokból ezért az A alcsaládba tartozó 9D4 elemet választottuk mintául a primer sorozat elkészítéséhez, mellyel ily módon a $H e T-A$ elemek A alcsaládjának expressziós szintjét és kópiaszámát tudtuk mérni.

Kontrollként vad típusú Oregon-R törzset használtuk, mivel a prod mutációt eredetileg Oregon-R genetikai háttéren izoláltuk. Pozitív kontrollként a HP1 capping fehérjét kódoló Su(var)205 gén két különböző allélját használtuk, melyekről korábbi eredmények igazolták, hogy megemelkedett HeT-A expressziót és a telomer hosszának növekedését okozzák (Savitsky és mtsai., 2002).

$\mathrm{Az}$ eredményeket a 15. ábra foglalja össze, melyből leolvasható, hogy a HeT-A transzkriptumok szintje $\mathrm{Su}(\mathrm{var}) 205^{2} / \mathrm{CyO}$ legyek petefészkében a 42-szeresére, $\mathrm{Su}(\mathrm{var}) 205^{4} / \mathrm{CyO}$ legyek petefészkében pedig 17-szeresére emelkedett az Oregon-R-hez képest. Ezek az eredmények megerösítik, hogy a Su(var)205 által kódolt HP1 a HeT-A transzkripció represszora (Perrini és mtsai., 2004).

A prod mutánsok petefészkeiben szintén megemelt $H e T-A$ transzkriptum szintet mértünk, amely a $\operatorname{prod}^{k 08810} / \mathrm{CyO}$ null allél esetében 6,5-ször, míg prodH/CyO szintén null allél esetében 12,5-ször magasabbnak bizonyult, mint az Oregon-R kontrollban. Ez arra utal, hogy a Prod szintén a HeT-A transzkripciós represszoraként müködik, ami jól megfelel korábbi eredményeinknek, melyek a Prod kromoszóma kondenzációban betöltött szerepére utaltak (Török és mtsai., 2000; Török és mtsai., 1997).

A megemelt expressziós szint megemelt retrotranszpozíciót és telomerhossz növekedést okozhat, ezért megvizsgáltuk, hogy a $\mathrm{prod} / \mathrm{Cy} O$ heterozigóta legyekben a törzs 13 éves fenntartása során megváltozott-e a HeT-A kópiaszáma. Ezt kvantitatív PCR-rel (qPCR) vizsgáltuk ugyanazon nőstény egyedek szöveteiben, melyek petefészkéből az expressziós szintet is mértük. A HeT-A szekvenciákat ugyanazon specifikus GAG-ORF primer sorozattal amplifikáltuk és a kapott $\mathrm{Ct}$ értékeket a riboszómális S17 fehérje (RpS17) génjének 
kópiaszámához normalizáltuk, hogy kiküszöböljük az esetleges DNS koncentráció különbségekből adódó eltéréseket.

A 15. ábrán bemutatott mérési eredmények azt mutatják, hogy a pozitív kontrollként használt Su(var)205²/CyO legyek HeT-A kópiaszáma átlagosan 10,7-szerese az Oregon-R vad típusnak, míg ugyanezen gén másik változatát hordozó $\mathrm{Su}(\mathrm{var}) 205^{4} / \mathrm{CyO}$ legyek telomerei csak 2,8-szor hosszabbak az Oregon-R legyekéhez képest. Ez nagyjából megegyezik a Savitsky által korábban mért adatokkal (Savitsky és mtsai., 2002). A null allél $\operatorname{prod}^{k 08810} / C y O$ és prodH/CyO legyekből kivont DNS ezzel szemben közel azonos számú HeT-A elemet tartalmazott, mint az Oregon-R. Ez az eredmény arra enged következtetni, hogy a prod géndózis 50\%-os csökkenése következtében megemelkedő HeT-A transzkripciós szint a Su(var)205-el ellentétben nem befolyásolja a transzpozíciók gyakoriságát és a telomerek hosszát.

Ha figyelembe vesszük az egyetlen $H e T-A$ elemre eső transzkripció szintjét az eredmény még meglepőbb. Az egyes HeT-A elemek átírása hozzávetőlegesen 3,9-szer nagyobb a $\mathrm{Su}(\mathrm{var}) 205^{2} / \mathrm{CyO}$ és 6,3-szor nagyobb $\mathrm{Su}(\mathrm{var}) 205^{4} / \mathrm{CyO}$ legyek petefészkében, mint Oregon-R legyekében, míg $\operatorname{prod}^{k 08810} / C y O$ legyekben ez az érték 6,5-szöröse, prodH/CyO legyekben pedig 12,5-szöröse a vad típusénak (15. ábra).

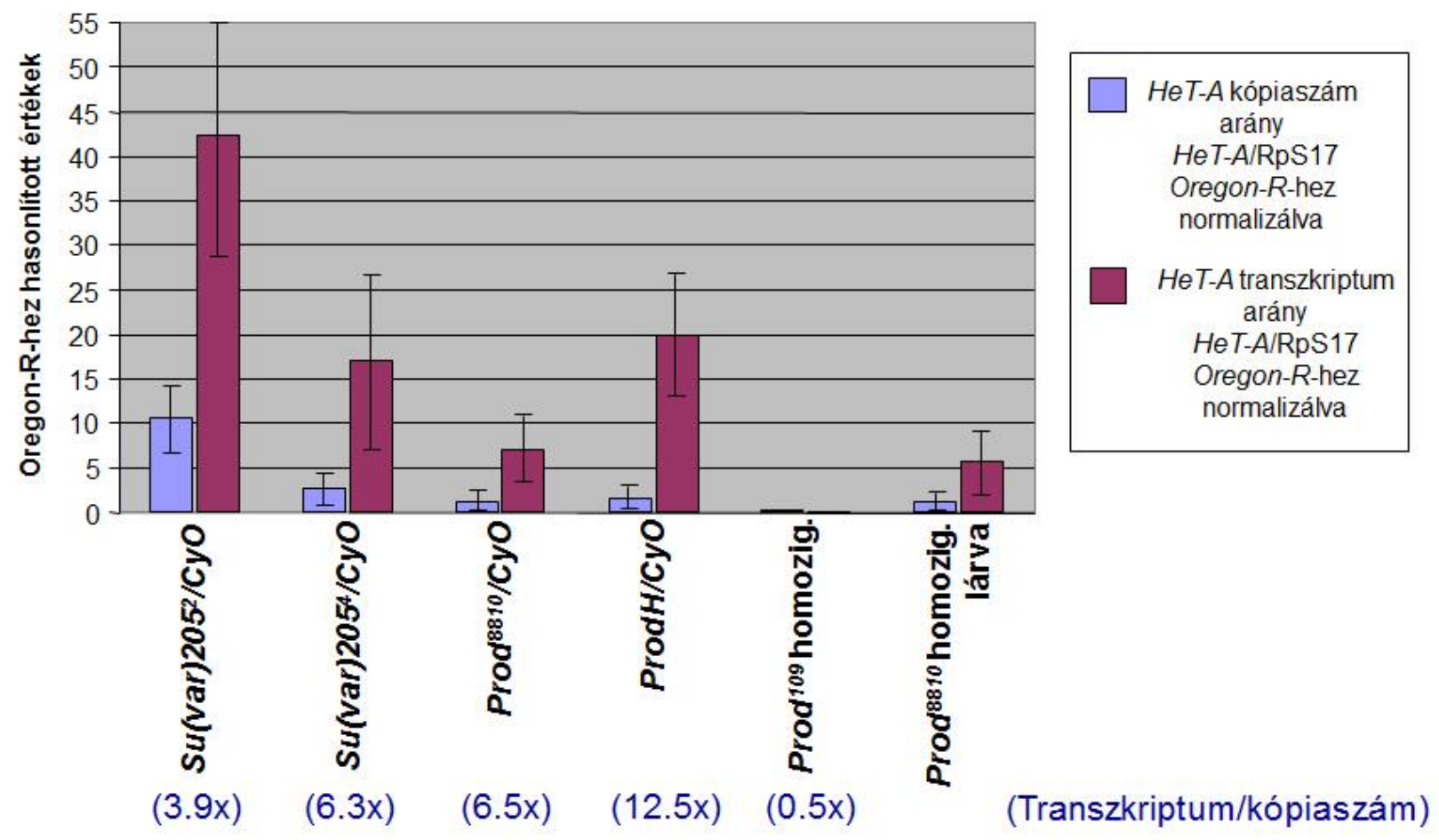


15. ábra. Kvantitatív PCR-rel meghatározott HeT-A kópiaszámok genomikus DNSben, illetve ezek transzkriptum szintjei különböző Su(var)205 és prod legyek petefészkében.

A genetikai háttér lehetséges hatásának kizárása érdekében megvizsgáltuk a prod109 allélt is, ami a $P\{l a c W\}$ inszercióval létrejött $\operatorname{prod}^{k 08810} / C y O$ allél $\mathrm{P}$ elem kiugratással létrehozott homozigóta életképes revertánsa. Ebben az életképes prod revertánsban a telomerek az Oregon-R-nél is rövidebbnek bizonyultak, de ami még fontosabb, hogy a HeT-A transzkriptum szint is alacsonyabb a vad típusban mértnél. A mindegyik kísérletben belső kontrollként használt jockey kópiaszáma és transzkripciós szintje nem mutatott jelentős

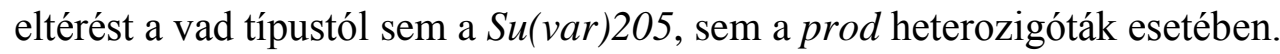

Mivel ismert, hogy adult petefészekben a TART és kisebb mértékben a HeT-A elem transzkriptum szintjét RNSi mechanizmus is szabályozza (Savitsky és mtsai., 2006), ezért

megvizsgáltuk 3. stádiumú lárvák $H e T-A$ transzkriptum szintjét is. $\operatorname{prod}^{k 08810}$-lárvákban 5,7szeres, míg prodH lárvákban 7,9-szeres emelkedést tapasztaltunk a vad típusú Oregon-R-hez képest.

Ezen eredmények alapján úgy gondoljuk, hogy a vad típusú Prod fehérje represszió alatt tartja a HeT-A transzkripciós szintjét, de ez meglepő módon mégsem emeli a transzpozíciók gyakoriságát a fehérje hiányában. Ennek az lehet az oka, hogy a $S u(v a r) 205$ mutánsokkal ellentétben prod mutánsokban a capping komplex épsége megakadályozza a hatékony retrotranszpozíciót.

\section{Élesztő két-hibrid szürés}

Az élesztő kettős hibrid rendszerrel végzett kísérlet során sikeresen azonosítottunk Prod-dal kölcsönható fehérjéket a teljes prod cDNS-t használva csaliként. A Drosophila embrionális cDNS könyvtárból 120000 cDNS klón szürését végeztük el az Anyagok és módszerek fejezetben részletesen ismertetett módon. A kölcsönható klónokat a kölcsönhatás erőssége alapján csoportosítottuk, a $\beta$-galaktozidáz festés intenzitása alapján, és a száz legerősebb kölcsönható partner klónját megszekvenáltattuk. Ezek közül a 2. táblázatban csak azt a 18 lehetséges interaktort mutatjuk be, meyeket több független klón is azonosított, vagy feltünően erős festődést mutattak, illetve bármi módon kapcsolatba hozhatóak a telomerrel. Mivel a kölcsönhatásokat nem erösítettük meg további független in vitro módszerrel, ezért 
ezeket a fehérjéket csak olyan lehetséges jelöltnek tekintettük, melyek Prod-kölcsönhatása és esetleges telomerikus funkciója további igazolást igényel.

\begin{tabular}{|c|c|c|c|}
\hline gén neve & fehérje funkciója & $\begin{array}{c}\text { találatok } \\
\text { száma }\end{array}$ & $\begin{array}{c}\text { kölcsönhatás } \\
\text { erőssége }\end{array}$ \\
\hline Uba2 & Smt3 aktiváló enzim & 6 & erös \\
\hline prod & DNS-kötő fehérje & 4 & erös \\
\hline$N c 73 E F$ & oxoglutarát dehidrogenáz & 3 & erös \\
\hline Cys & cisztein proteáz inhibitor & 2 & erös \\
\hline CG4847 & cisztein peptidáz & 2 & erös \\
\hline windei & H3K9 metil transzferáz kofaktora & 2 & erös \\
\hline bip2 & TAFII155, DNS-kötő fehérje & 2 & erös \\
\hline CG5001 & chaperon & 2 & erös \\
\hline NaCP60E & Na-ion transzporter & 2 & erös \\
\hline dhd & diszulfid oxidoreduktáz & 2 & közepes \\
\hline$l w r$ & SUMO konjugáló enzim & 1 & erös \\
\hline CG9797 & cink-ujj transzkripciós faktor & 1 & erös \\
\hline phol & cink-ujj transzkripciós faktor & 1 & erös \\
\hline CG4557 & transzkripciós faktor & 1 & erös \\
\hline CG31365 & cink-ujj transzkripciós faktor & 1 & erös \\
\hline Chro & kromatin kötő fehérje & 1 & erös \\
\hline$p z g$ & DNS-kötő interband fehérje & 1 & erös \\
\hline$E(z)$ & hiszton metiláló fehérje & 1 & gyenge \\
\hline
\end{tabular}

2. táblázat. Az élesztő két-hibrid kísérletben azonosított Prod-dal kölcsönható fehérjék. A lista csak a többször azonosított, erős jelet adó, illetve a telomerhez kapcsolható fehérjéket tartalmazza.

Az azonosított kölcsönható partnerek közt megtalálható maga a Prod fehérje is, ami számunkra különösen fontos, mivel korábbi munkáinkban csak közvetett bizonyítékunk volt arra, hogy a Prod multimerként kötődik a DNS-hez (Török és mtsai., 2000), ami ezzel közvetlen igazolást nyert. 
Azonosításra került a táblázatban nem mutatott CG15107 ismeretlen fehérje is, melynek génje a prod génnel közvetlenül szomszédos és annak közeli homológja. Ez arra utal, hogy ez az eddig teljesen ismeretlen fehérje a prod gén duplikációjával keletkezhetett, és a Prod-dal hasonló funkciókban vehet részt.

Számos egyéb DNS-kötő fehérjét is azonosítottunk mint Prod interakciós partnert, amely megerősíti azt a feltevésünket, hogy a Prod más DNS-kötő fehérjékkel kölcsönhatva kötődik a kromatinhoz, és a kötőhelyek kombinációja a DNS-en alapvetően megszabhatja a lokalizációt. Példaként a CG9797, a CG4557 és a CG31365 olyan nem jellemzett transzkripciós faktorok, melyek szintén kölcsönhatásba lépnek a Prod fehérjével csakúgy, mint a Pleiohomeoticlike (phol) cink-ujj fehérje, mely egy Polycomb csoportba tartozó DNSkötő fehérje és szupresszor komplexekből ismert. Különösen feltünő a nagyszámú transzkripciós faktor, melyek mindegyike PolII által átírt promótereken müködik, mint például a 2. táblázatban nem mutatott Regena, female sterile (1) homoeotic, Trap36, CG9797, CG31365. Ez megerősíti a Prod feltételezett génregulációs szerepét, és arra utal, hogy a Prod komplex az eukromatinon is promóterek müködését befolyásolhatja.

Nagyszámú olyan kölcsönható fehérjét azonosítottunk, amelyek általános sejtfunkciókban vesznek részt, mint a fehérjék SUMO általi módosítása, lebontása (Uba2, lesswright - szumoilálás, ubiquitinálás), transzportja ( $\beta^{\prime}$-coatomer protein, Golgi-készülék transzport fehérje), hasítása (Cystatin-like, proteáz inhibitor), stb. Ezek minden bizonnyal valódi interakciót jelentenek, de a vizsgált funkció szempontjából nem tulajdonítunk nekik jelentőséget.

Az Smt3 activating enzyme 2 (Uba2) hat alkalommal került azonosításra, míg a $l w r$ gén által kódolt Ubc9 (SUMO-specifikus E2 konjugáló enzim) az egyik legerösebb interakciót mutatta. Mivel a szumoilációs útvonal ezen két fő tagja kölcsönható partnere a Prod-nak, feltételezhetjük, hogy a Prod fehérje szumoilálódik, vagy a szumoilációs komplexet köti ki Prod-interaktorok módosításához.

A Prod fehérje telomerikus szerepének vizsgálatához szorosan köthető azon eredményünk, miszerint a Z4 és az ahhoz kapcsolódó Chromator fehérjék mindegyike képes a Prod fehérjéhez kapcsolódni. A Z4 egyike az ezidáig azonosított kevés telomerikus HTT doménhez kötődő fehérjének (Andreyeva és mtsai., 2005). A Chromator (Chro), másnéven Chriz (Chromodomain protein interacting with Z4) fehérjét a Z4 fehérjével való interakciója alapján azonosították (Eggert és mtsai., 2004) és leírták, hogy az X és 2L telomereken jelen van (Gortchakov és mtsai., 2005). A Chro közvetlen interakciós partnere a JIL-1 kináz (Rath és mtsai., 2006) és ez a három fehérje (Chro, Z4 és JIL-1) tökéletes kolokalizációt mutat a 
politén kromoszómák interbandjeiben. Biztató, hogy a Z4 és a Chro is azonosításra került a Prod-dal való szürésben, ami alapján feltételezhető azon kromoszómális lókuszokban ahol mindegyik jelen van (pl. a HTT doménen) egy közös komplexet alkothatnak.

A Chro és Z4 fehérjék génjeinek mutáns fenotípusa arra utal, hogy mindkettő részt vehet a kromatin szorosabbra csomagolásában, ami megfelel egy lehetséges Prod-dal közös funkciónak mind a telomereken, mind az egyéb kromoszómális szakaszokon.

\section{A Prod közvetlenül köti a Chromator-t in vivo}

Annak érdekében, hogy in vivo igazoljuk a lehetséges Prod-Chromator és Prod-Z4 kölcsönhatásokat, koimmunprecipitációs kísérleteket végeztünk S2 sejtek kivonatából. A 16. ábra szemlélteti, hogy a Chromator koimmunprecipitálható Prod-dal és ezen fehérjék egy kis része kapcsolódik in vivo.

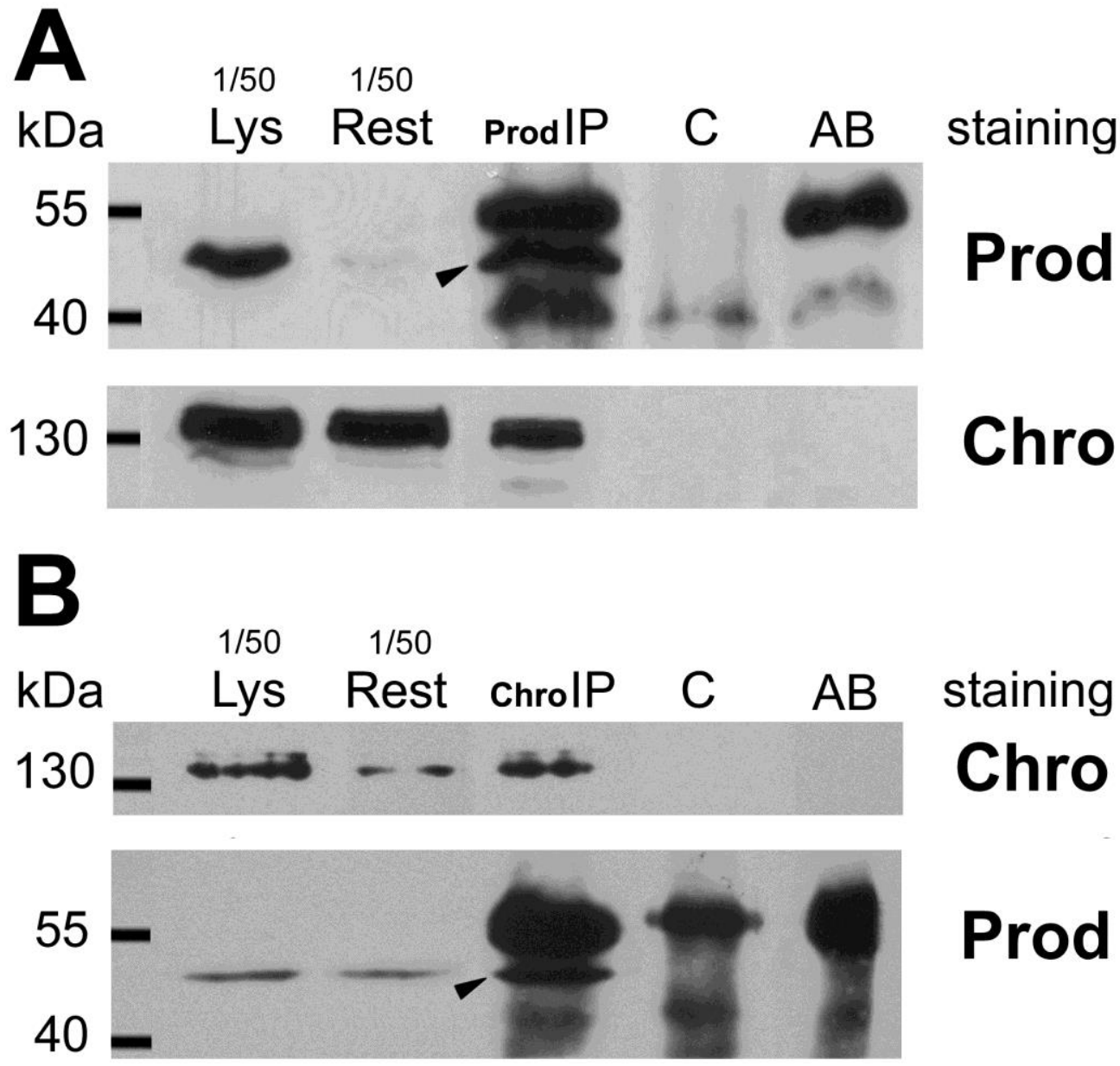


16. ábra. Prod és Chro fehérjék koimmunprecipitálása S2 sejtekböl. (A) Ugyanazon filter duplikátuma felül nyúl-anti-Prod, lent nyúl-anti-Chro ellenanyaggal festve. A Liz sávban a teljes lizátumot futtattuk. A ProdIP sávban nyílhegy jelzi, hogy a Prod fehérjét sikerrel kicsaptuk a lizátumból, de mivel a Western blotban használt anti-nyúl másodlagos ellenanyag a kicsapáshoz használt nyúl-anti-Prod ellenanyagot is felismeri, azok a Prod fehérje alatt és felett két erősebb sáv formájában jelennek meg. Ezt bizonyítja az AB sáv, melybe csak nyúl-anti-Prod ellenanyagot vittünk fel. A Rest jelzésủ sávban látható, hogy a lizátumban a precipitálás után csak igen kevés Prod fehérje maradt. Az alsó, Chro fehérjére festett filteren látható, hogy a ProdIP sávban a Prod fehérjével együtt a Chro fehérje is koimmunprecipitálódott, de ez a lizátum teljes Chro tartalmának csak töredéke, mivel a Rest sávban nagy mennyiségü Chro maradt az immunprecipitálás után. A koimmunprecipitált Chromator aránya kiszámítható: A Prod fehérjére festett ProdIP sáv a teljes immunprecipitátum 1/20 részét tartalmazza, míg a Chromator fehérjére festett ProdIP sávban futtattuk az immunprecipitátum 19/20-ad részét (a felső és alsó filter csak ennyiben különbözik). Mivel mind a Liz mind a Rest jelzésủ sávban az IP-hez használt teljes extraktum 1/50-ed része futott, és a ProdIP sávban detektált Chro mennyisége kb. fele lehet a Rest sávban detektált Chro mennyiségének, ebből az következik, hogy az össz Chromator kevesebb, mint 1/100ad részét koimmunprecipitáltuk, vagyis ennyi kötődhet a Prod fehérjéhez in vivo. A kontroll sávban (K) látható, hogy a Prod, ill. Chro ellenanyagok nélkül végzett immunprecipitátumok nem tartalmaznak se Prod, se Chromator fehérjét.

(B) A reciprok kísérlet, melynek menete teljesen azonos a fentiekkel, kivéve, hogy itt a Chromator fehérjét immunprecipitáltunk S2 sejt extraktumból. Az alsó filter jelzi, hogy az összes Prod fehérje kis része koimmunprecipitálódott a Chromator-ral (nyílhegy).

Ez az eredmény megerősíti az élesztő két-hibrid kísérlet eredményét és arra utal, hogy a Prod közvetlenül köti a Chromator fehérjét in vivo. A Prod-Z4 kölcsönhatást nem tudtuk ily módon igazolni, de az ismert Chromator-Z4 interakció alapján feltételezhetünk egy közös komplexet, melynek mindhárom fehérje tagja, legalábbis a kromoszóma azon helyein, ahol mindegyik kolokalizálódik. 


\section{A fehérjék telomerikus lokalizációja immunfestések alapján}

Ha a Chro, Z4 és Prod fehérjék közös komplexet alkotnak a telomereken, akkor annak a HTT doménen kell lokalizálódnia. Hogy megvizsgáljuk az esetleges Prod-Chro/Z4 kolokalizációt a HTT doménen, immunfluoreszcens festéseket végeztünk Telomere elongation (Tel)/Oregon-R hibrid politén kromoszómákon. Fentebb már bemutattuk, hogy a jóval hosszabb HTT szakasszal rendelkező Tel homológ segít a HTT doménhez kapcsolódó fehérjék azonosításában (Andreyeva és mtsai., 2005; Török és mtsai., 2007). Mivel a rendelkezésünkre álló Prod és Chromator ellenanyagok egyaránt nyúlban készültek, nem tudtuk őket ugyanazon preparátumok festésére együtt használni.

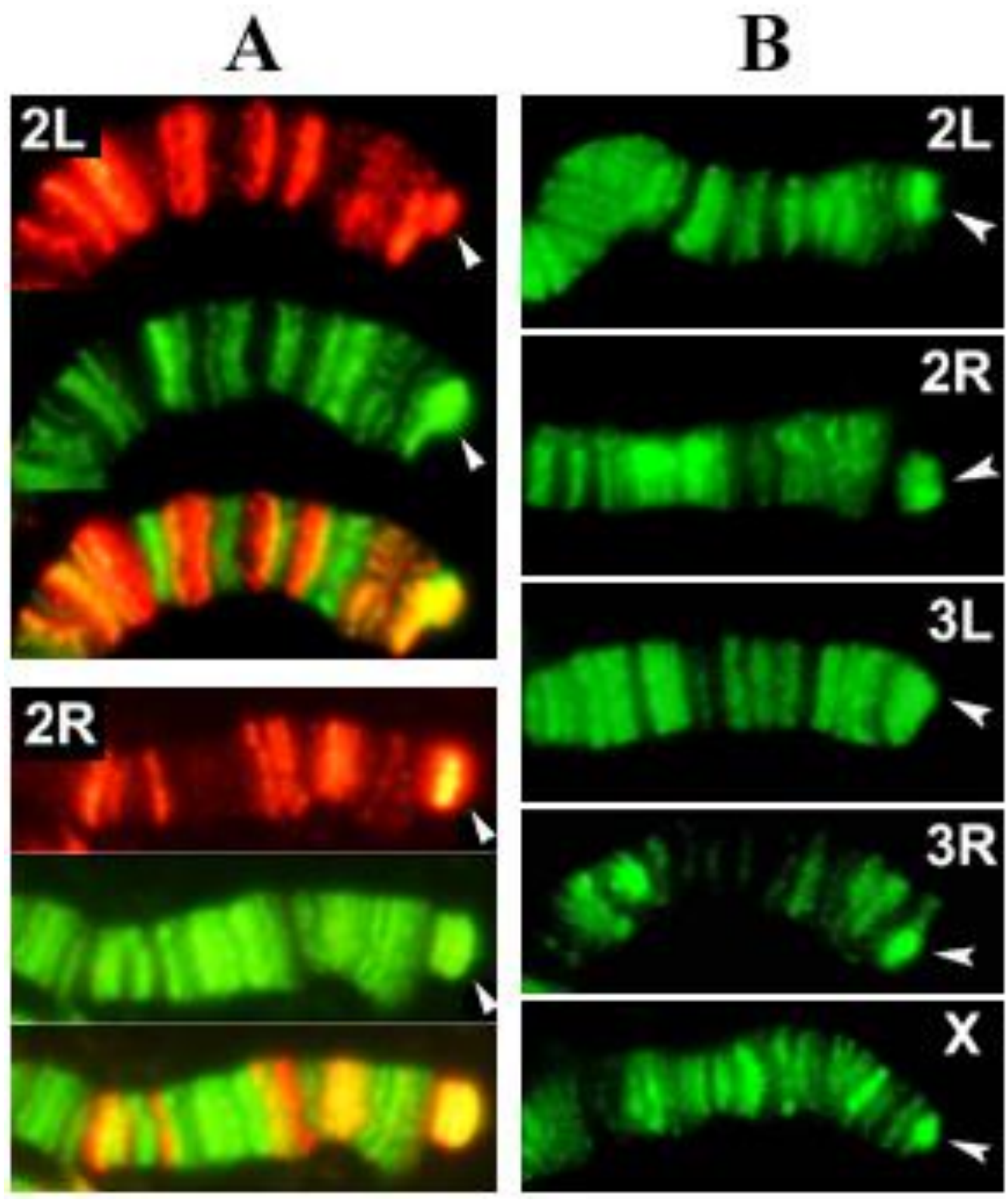


17. ábra. A Prod, Z4 és Chromator egyaránt a HTT sorhoz kötődik a telomereken. (A) Oregon-R/Tel politén kromoszómák kettős festése anti-Prod (piros) és anti-Z4 (zöld) ellenanyaggal. A képeken csak a $2 \mathrm{~L}$ és $2 \mathrm{R}$ telomerek láthatóak, de a többi telomer is hasonlóan festódik. A Prod és a Z4 festési mintázata a kromoszóma karokon eltér, de mindkét fehérje jelen van az összes telomer túlnyúló Tel HTT során (nyílhegyek), amit a kettős festések erős sárga színe is mutat. (B) Oregon-R/Tel politén kromoszómák anti-Chro festése a Prod és Z4 fehérjékhez hasonló telomerikus mintázatot mutat, a Chromator a Tel homológ túlnyúló HTT szakaszát erősen festi (nyílhegyek).

Eredményeink alapján a Z4 az összes kromoszóma HTT során kolokalizál a Prod-dal (17. ábra A). Ez megerősíti azt a korábbi megfigyelést, miszerint a Z4 kötődik a HTT-hez (Andreyeva és mtsai., 2005). A Chromator szintén jelen van az összes telomer HTT doménjén (17. ábra B), ami új eredménynek számít, mert egy korábbi közleményben (Gortchakov és mtsai., 2005) a Chro jelenlétét csak két telomeren, az $\mathrm{X}$ és $2 \mathrm{~L}$ végeken észlelték. Eredményeink azt mutatják, hogy a Chromator és a Z4 nem csak a korábban közölt interbandekben, hanem a telomerek HTT doménjén is tökéletesen kolokalizálódik (18. ábra), és ez teljesen egybeesik a Prod telomerikus lokalizációjával is (Török és mtsai., 2007) (9. ábra). Nagyméretü terminális deficienciák, melyek a TAS és HTT domént is eltávolítják, megszüntetik a Z4/Chromator/Prod telomerikus kötöhelyeket, azonban önmagában a TAS domén eltávolítása nem érinti egyik fehérje telomerikus kötődését sem (18. ábra). Eszerint a telomereken a HTT domén szolgál a potenciális Z4/Chromator/Prod fehérje komplex elsődleges kötőhelyeként.

Z4

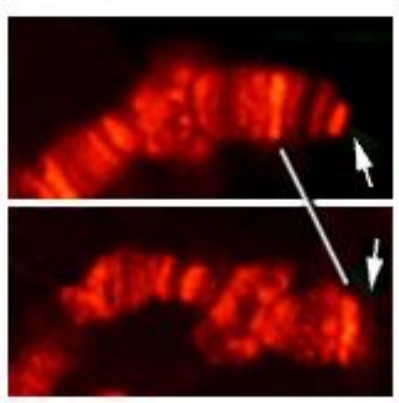

Chro

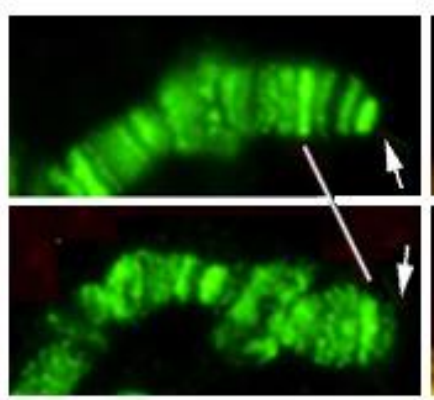

együtt

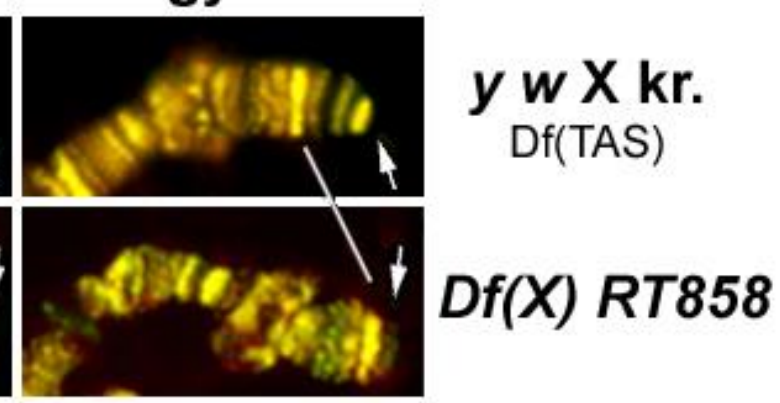


18. ábra. A Z4 (piros) és Chromator (zöld) lokalizációja tökéletesen azonos mind az interbandekben, mind a telomereken (nyilak). A $y w$ törzs $\mathrm{X}$ kromoszómájáról hiányzik a TAS domén (Abad, 2004a), azonban a Z4 és a Chromator telomerikus lokalizációja a vad típushoz képest (nincs feltüntetve) nem változik. A $D f(1) R T 858$ terminális deléció (a fehér vonal az azonos $1 \mathrm{C}$ bandeket köti össze) eltávolítja mind a TAS, mind a HTT domént, de funkcionális capping komplex található rajta (Biessmann és mtsai., 1990). Az erős telomerikus Z4 és Chromator festődés eltünik a deletált kromoszómavégröl, tehát a fehérjék nem a cap részei, hanem a HTT-hez kapcsolódnak.

Bár a Prod és a Z4/Chro fehérjék telomerikus festődésének mintázata megegyezik, a nagyszámú eltérő genotípusú kromoszómák festése során eltérő intenzitással festődő telomereket is találtunk (19. ábra). Például a Tel mutáns X kromoszómájának HTT doménjét a Z4 (és a Chro) erősen festi, míg a Prod viszonylag gyengébben. Az Oregon-R X kromoszóma esetében ez pont fordított, a Prod erősen, a Z4 gyengébben festi ezt a telomert. Ez a mintázat megmarad a heterozigóta Tel/Oregon-R X telomereknél is, függetlenül a keresztezés irányától (19. ábra). Mivel ugyanezen genom többi telomere nem mutatja ezt a festődési eltérést azt feltételezzük, hogy a Tel és az Oregon-R X kromoszómák kromatin/DNS összetétele jelentősen különbözhet egymástól.
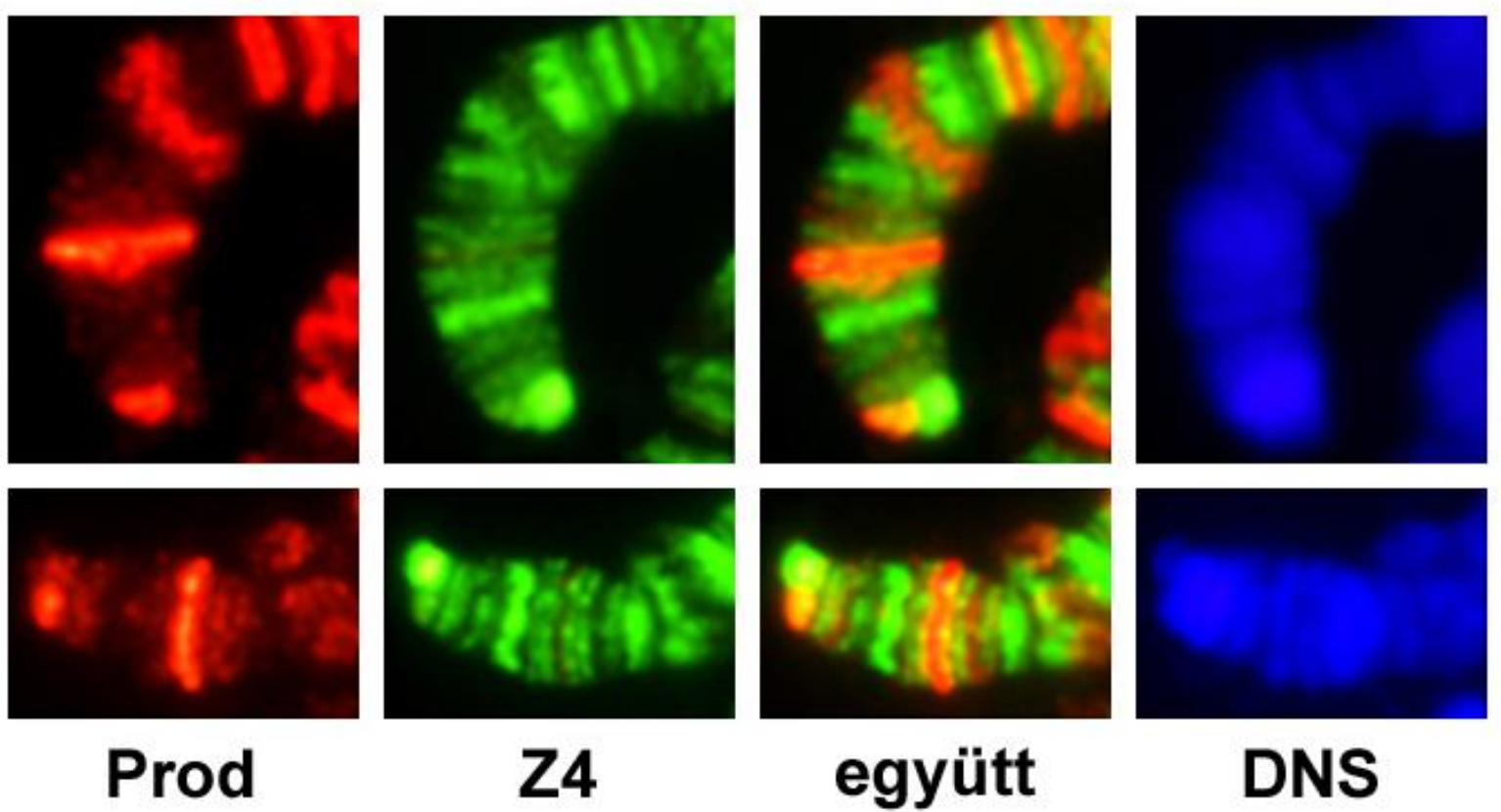

együtt

DNS 
19. ábra. Heterozigóta Tel/Oregon-R X kromoszómavégek immunfluoreszcens kettős festése Prod (piros) és Z4 (zöld) fehérjére. A DNS kék színnel jelölve. Látható, hogy a Prod az Oregon-R homológhoz erősebben, a hosszabb Tel homológhoz gyengébben kötődik, míg a Z4 fehérje esetében épp fordított a helyzet. (A Chro festés intenzitása mindegyik kromoszómán a Z4 mintázatával egyező.)

Érdekes módon a telomerek eredeti kromatin/DNS összetétele a telomerek hosszának változása esetén is megőrződni látszik. A Tel mutáció néhány generáció alatt az Oregon-R eredetü, vad típusú rövid telomerek drasztikus meghosszabbodását okozza (Siriaco és mtsai., 2002). Ily módon több, különböző eredetü rövid telomer is meghosszabbítható, és festési mintázatalapján ezután összehasonlíthatjuk azok fehérje összetételét. Egy kísérlet során egy Oregon-R eredetü X kromoszóma telomerét de novo meghosszabbítottuk oly módon, hogy a 3. kromoszómára bevittük a Tel mutációt, és a vonalat 10 generáció során fenntartottuk, hogy kellő időt biztosítsunk a telomer növekedéshez. Az így meghosszabbított X kromoszóma HTT doménje az eredeti Tel törzs telomerétől eltérően mind Prod, mind Z4 ellenanyaggal erős festődést adott (20 ábra B). Ez arra utal, hogy a hosszabbodás során megőrződhetett az eredeti Oregon eredetü X telomer kromatin/DNS összetétele. A két eltérő kromatin összetételü telomer arra is következtetni enged, hogy a Prod telomerikus lokalizációja nem feltétlenül függ a Chromator-tól.
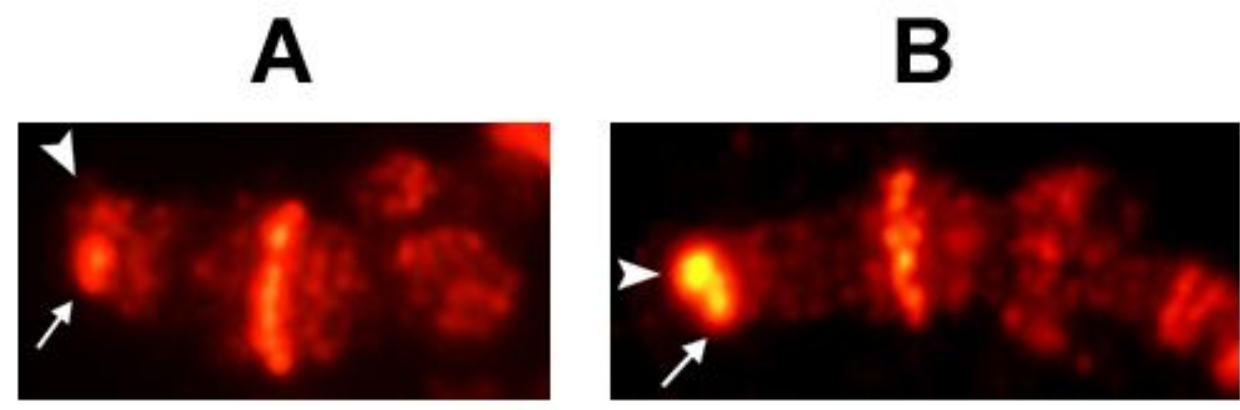

\section{Prod}
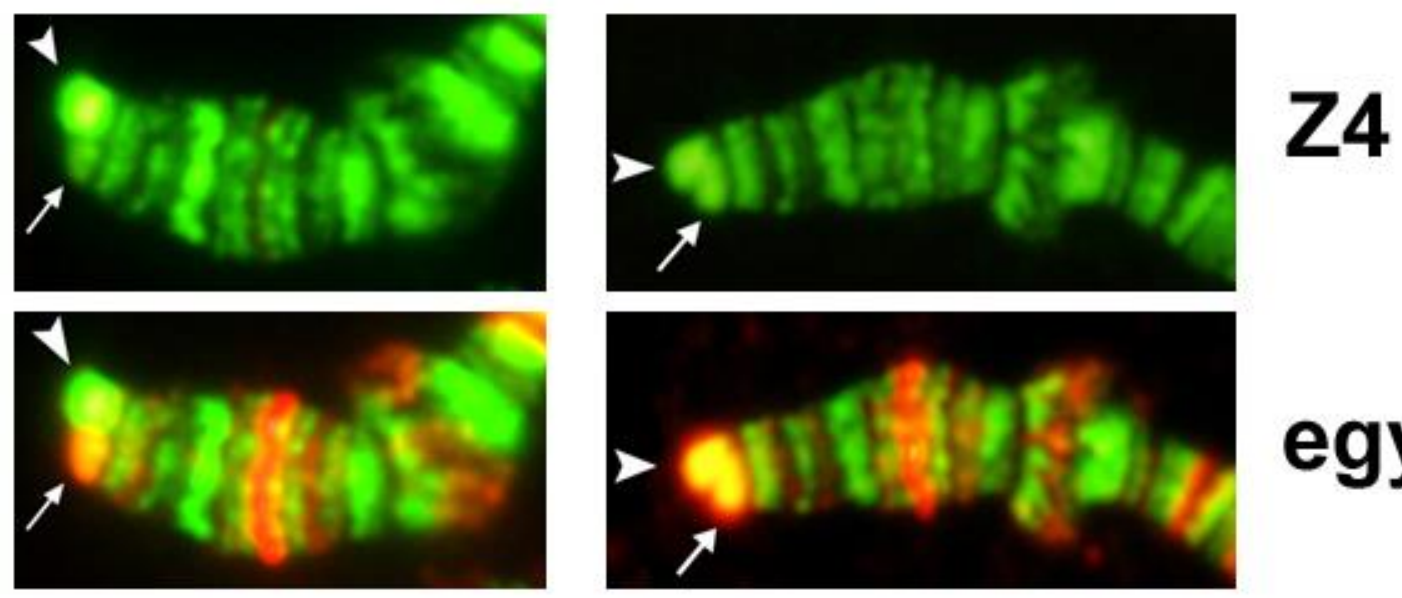

együtt 
20. ábra. Heterozigóta $X$ kromoszómák telomerei $Z 4$ (zöld) és Prod (piros) kettős festéssel. Az A ábrasor azonos a 18. ábra Tel/Oregon-R kromoszómájával. A B ábrasor olyan heterozigóta telomert mutat, melynek meghosszabbodott telomerét magunk állítottuk elő egy Oregon-R telomer meghosszabbításával. Magyarázatot lásd a fenti szövegben.

Mivel a Z4 része a TRF2/DREF és a NURF komplexnek (Hochheimer és mtsai., 2002; Kugler és Nagel, 2007, 2010), elképzelhető, hogy a HTT doménen jelenlévő Z4 is ezen komplexek része. Ennek eldöntésére megvizsgáltuk a DREF fehérje jelenlétét a HTT doménen a már fent bemutatott immunfestési módszerekkel. Azt találtuk, hogy a DREF az összes telomer HTT szakaszán nagy mennyiségben jelen van (21. ábra), ami azt jelentheti, hogy az egész TRF2/DREF komplex jelen lehet a telomereken. Ez érthetővé teszi, hogy miért találták korábban a HTT domént eukromatikus szerkezetűnek (Biessmann és mtsai., 2005b).
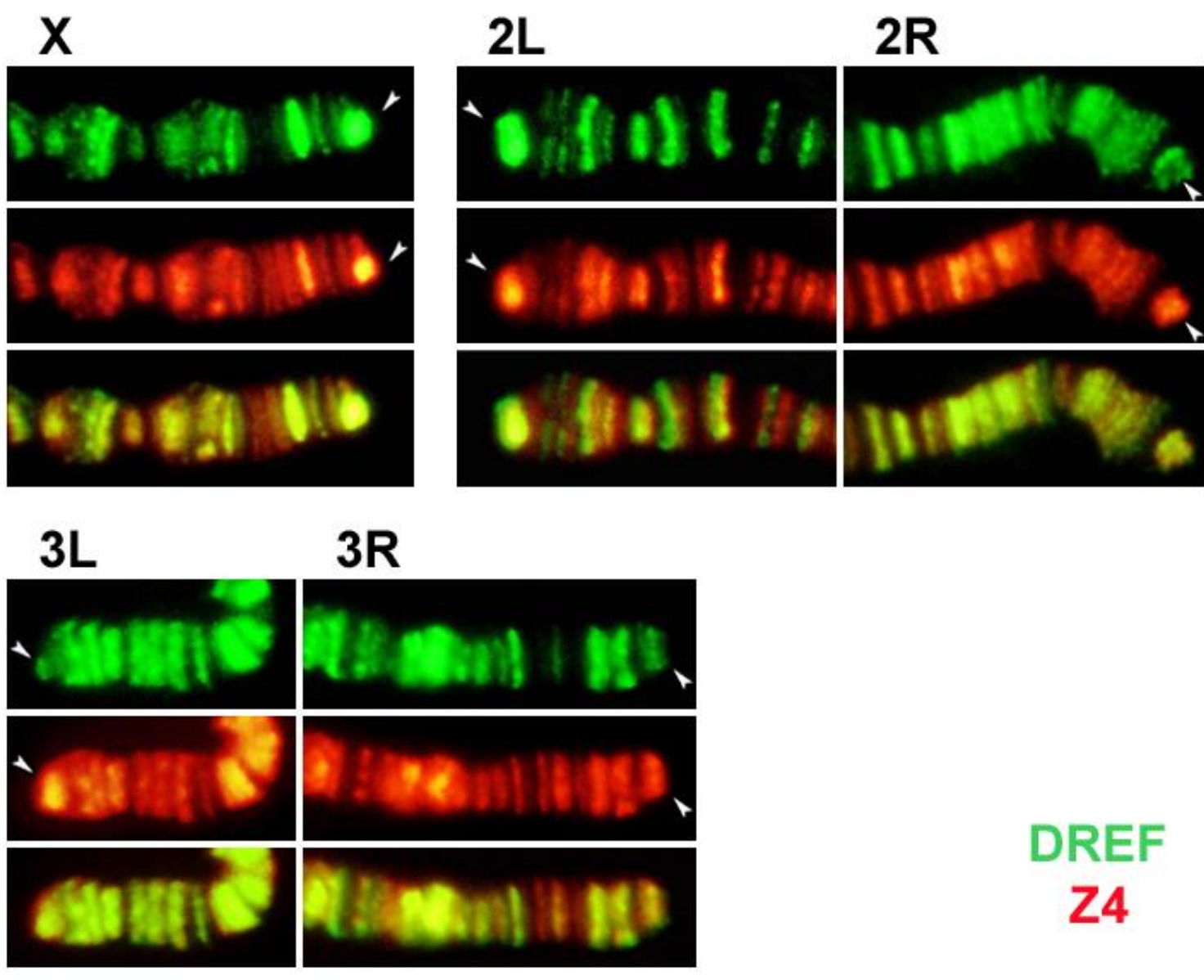
21. ábra. A DREF kolokalizál a Z4 fehérjével a HTT doménen. Oregon-R/Tel politén kromoszómák telomereinek anti-Z4 (piros) és anti-DREF (zöld) ellenanyagokkal való kettős festése bizonyítja, hogy a Tel homológ megnyúlt HTT doménjéhez (nyílhegyek) mindkét fehérje kötődik.

\section{A Prod szerepe a HTT kromatin szumoiláltságában}

Az élesztő két-hibrid adatok alapján (2. táblázat) a Prod kölcsönhatásba léphet a szumoilációs enzim kaszkád két legfontosabb tagjával az Uba2 Smt3 aktiváló enzimmmel, és a $\boldsymbol{l w r}$ ubiquitin konjugáló enzimmmel. A Prod és a szumoilációs útvonal E1 aktiváló és E2 konjugáló enzimei közötti erős biokémiai interakció arra utal, hogy a Prod fehérje szumoilálódhat, vagy a vele együtt lokalizálódó fehérjék szumoilálódádát segíti azzal, hogy az adott lókuszhoz vonzza a szumoilációt végző enzimeket. A szumoiláció egy olyan poszttranszlációs fehérje módosítás, melynek során egy enzim kaszkád a $\sim 10$ kD nagyságú SUMO ( Small Ubbiquitin-like Modifier) fehérjét kovalensen kapcsolja a célfehérje megfelelő helyére (Talamillo és mtsai., 2008a). Ez a módosítás számos eukariótában az embertől az élesztőig lehetőséget nyújt a fehérjék aktivitásának, lokalizációjának, vagy funkciójának megváltoztatására (Wilkinson és Henley, 2010; Zhao, 2007). Minthogy az Smt3 az egyetlen SUMO homológ ecetmuslicában (Talamillo és mtsai., 2008b), a szumoilált fehérjék a politén kromoszómákon anti-Smt3 ellenanyaggal való festéssel azonosíthatóak. Az előzőekben bemutatott festési módszerekkel megvizsgáltuk a szumoiláció jelenlétét és eloszlását a telomereken (22. ábra). Az Smt3 telomerikus lokalizációja azt jelzi, hogy a HTT sor erősen szumoilált, és a mintázata egybeesik a Prod telomerikus lokalizációjával. Az Smt3 megtalálható végig a HTT soron, azonban jelentős szumoiláció nem tapasztalható a TAS és a telomerikus cap esetében sem. Továbbá Smt3 festődés látható a kromoszómavégeket összekötő kromatin hidakon is. 

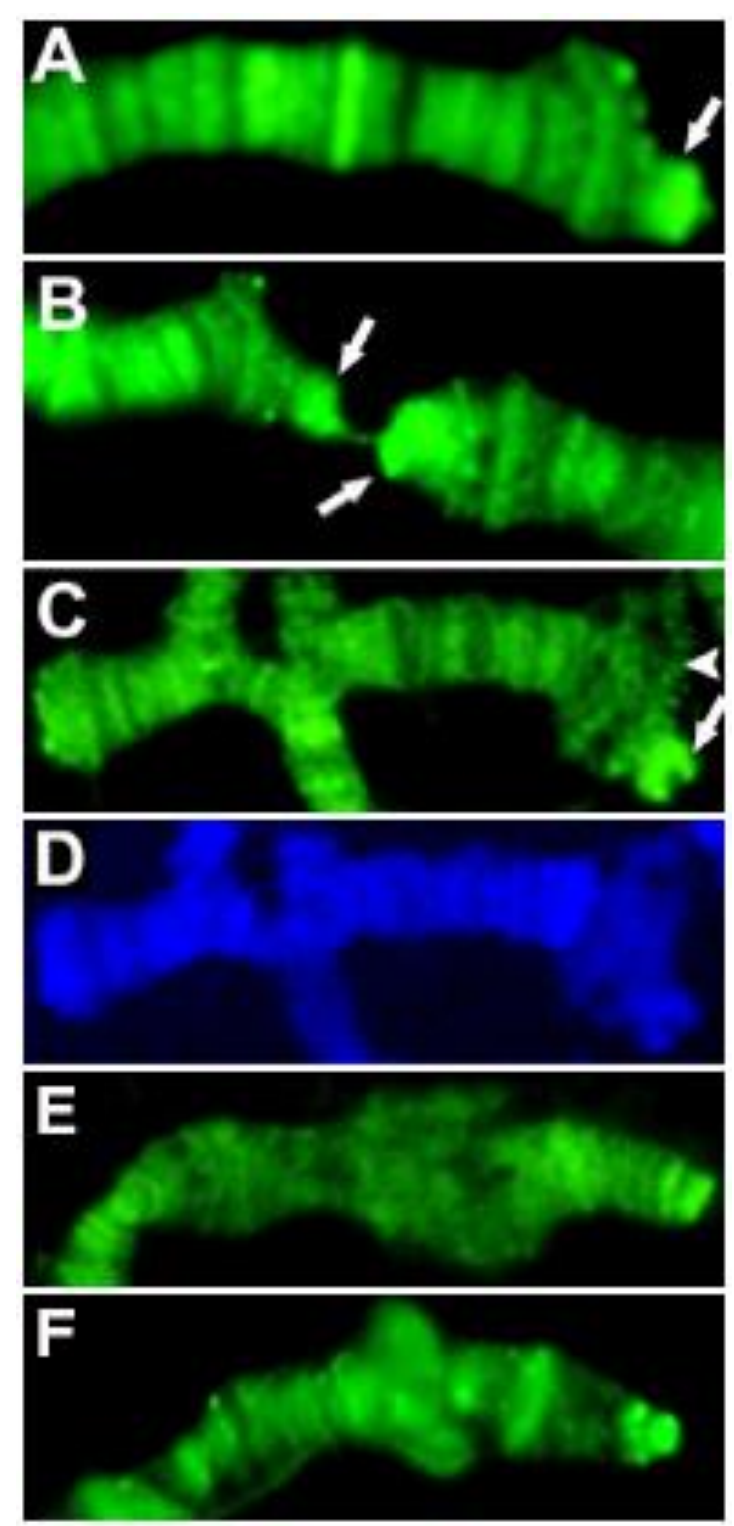

22. ábra. Politén kromoszómák Smt3 (SUMO) festése azt mutatja, hogy a HTT soron lévő fehérjék erősen szumoiláltak, míg a cap és a TAS szumoiláltsága nem kiemelkedő mértékü. A nyilak az Oregon-R/Tel kromoszómák erősen festődő túlnyúló HTT sorára mutatnak a $3 \mathrm{R}(\mathrm{A})$, valamint a $2 \mathrm{R}$ és $2 \mathrm{~L}$ (B) telomereken. (C) A terminális deficiencia $l(2) g l^{G B 26} / C y$ (Walter és mtsai., 1995) esetében csak a balanszer kromoszóma telomerén látható jelentős szumoiláció (nyíl), a terminálisan deletált, de capping komplexszel rendelkező kromoszómavégen nem (nyílhegy). (D) A C képen látható kromoszómavég DAPI festése. A vad típusú $\mathrm{X}$ kromoszóma telomerének (F) szumoilációs szintje megegyezik a TAS domén nélküli $y w$ kromoszóma telomerével (E), így feltehetőleg a TAS doménhez kapcsolódó fehérjék nem jelentősen szumoiláltak.

A célfehérjék SUMO módosítása egy konszenzus SUMO akceptor hely lizinjén történik (Sampson és mtsai., 2001), ezért megvizsgáltuk, hogy a Prod fehérjén megtalálható-e ez a célszekvencia. A SUMOplot ${ }^{\mathrm{TM}}$ Analysis Program-mal végzett vizsgálat azt mutatta, hogy a Prod fehérje három nagy és két kisebb valószínüségü szumoilációs helyet tartalmaz (23. ábra). A HTT fehérjék közül a Prod mellett a Chromator és a JIL-1 is tartalmaz két-három nagy valószínüségü SUMO akceptor helyet, míg a Z4 egyet sem. 


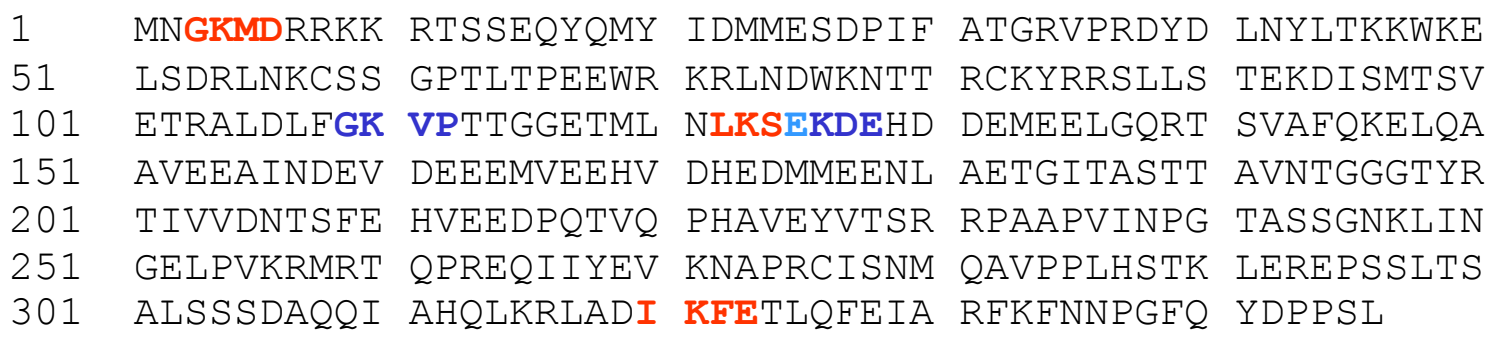

23. ábra. A Prod fehérje aminosav sorrendje és a jósolt szumoilációs helyek. A konszenzus SUMO akceptor hely: $\Psi \mathrm{KXE}$, ahol $\Psi$ hidrofób aminosav, $\mathrm{K}$ lizin, $\mathrm{X}$ bármilyen aminosav, E glutaminsav. Piros színnel a nagy valószínüségü SUMO akceptor helyek, kékkel az alacsonyabb valószínüségü helyek vannak feltüntetve, a világoskék szín a helyek átfedését jelzi.

Megpróbáltuk kísérletes módon is megvizsgálni, hogy a Prod fehérje szumoilálódik-e. Ennek céljából a Prod nagy valószínüségű SUMO akceptor helyei közül három, a 23. ábrán pirossal jelölt helyet egyenként elrontottunk oly módon, hogy helyspecifikus mutagenezissel (QuikChange II Site-Directed Mutagenesis Kit - Stratagene) argininre cseréltük a kulcsfontosságú lizin aminosav kódját (K4R; K123R; K321R) a prod cDNS-en, és a képződő fehérjét HA-taggel jelöltük. Ezt követően a vad típusú és a mutáns, N-terminális HA-taggel ellátott prod cDNS-t tartalmazó expressziós vektorokat S2 sejtekbe transzfektáltuk. Aktin promóter segítségével kifejeztettük a fehérjéket és azok lokalizációját konfokális mikroszkóp segítségével vizsgáltuk (24. ábra).

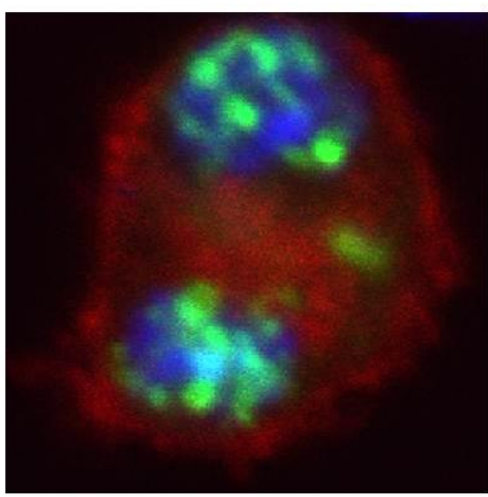

K123R

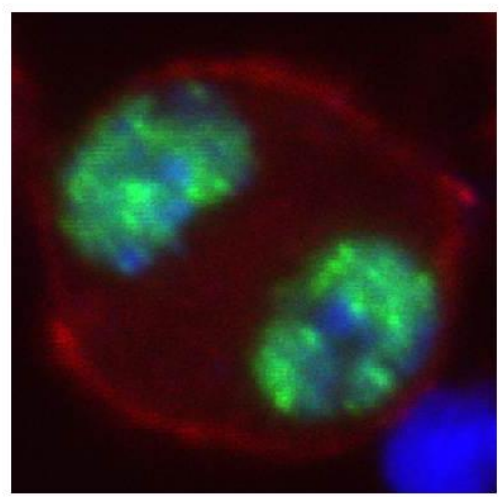

K321R

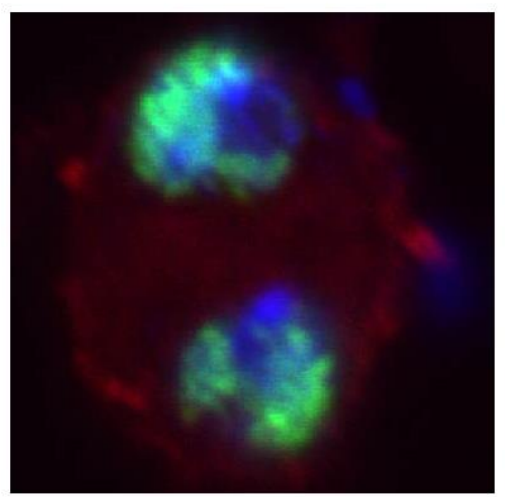

kontroll 
24. ábra. HA-Prod fehérjék kifejeződése transzfektált S2 sejtekben. A képeken osztódó sejtek láthatóak, ahol zöld színnel a HA-taggel jelölt fehérjék, kékkel a DNS és piros színnel az aktin jelölődik.

A kontrollhoz képest (vad típusú Prod fehérje HA-taggel) nem tapasztaltunk jelentős eltérést a mutáns változatok festődési mintázatában, mindkét esetben megmaradt a sejtmagi lokalizáció. Azonban a K123R mutánsnál a Prod festődési mintázat eloszlása észrevehetően megváltozik a sejtmagban, mintha bizonyos helyekről leszorulna a mutáns fehérje.

Megvizsgálva az ismert Drosophila rokon fajok Prod fehérje szekvenciáit, azt találtuk, hogy a 123. pozícióban lévő lizin és a szumoilációs enzimek által felismert LKSE motívum mindegyik fajban jelen van, ami erős konzerváltságra utal.

A transzfektált S2 sejtekből immunprecipitációs kísérleteket is végeztünk. A sejt extraktumból anti-HA ellenanyag segítségével fehérjét tisztítottunk, majd Western blottal próbáltuk kimutatni a szumoilált Prod változat jelenlétét a mintában. Ezt azonban technikai okok miatt teljes bizonyossággal nem sikerült igazolni.

A Prod fehérje HA-tagelt vad és mutáns változatait megpróbáltuk transzgenikus legyekben kifejeztetni, hogy azok lokalizációját vizsgálhassuk. A transzgenikus legyekből azonban nem sikerült kimutatni a HA-tagelt fehérjéket, melynek legvalószínübb oka az, hogy az általunk használt szabályozó szakasz nem müködött.

\section{Telomerhossz vizsgálata heterozigóta mutánsokban}

A HTT domén kromatin állapota a retrotranszpozíció és a génkonverzió szabályozásán keresztül befolyásolhatja a telomerek hosszát (Capkova Frydrychova és mtsai., 2008). Heterozigóta mutánsokban, ahol csak egyetlen vad típusú allél található, csökken a génről képződő fehérje mennyisége, null mutánsokban elméletileg csak fele annyi fehérje képződik, mint a homozigóta vad típusban. Ez a csökkent fehérjekoncentráció fenotipikus változást eredményezhet, amennyiben a vad fenotípus kialakításához szükséges fehérje mennyisége meghaladja a normális szint 50\%-át. Példaként a HP1 ilyen dózisérzékeny gén a telomereken, mert a HP1 heterozigótákban a csökkent génaktivitásnak köszönhetően megnő a telomerek hossza (Savitsky és mtsai., 2002).

Kvantitatív PCR segítségével megvizsgáltuk, hogy az ismert HTT kromatin fehérjéket kódoló gének csökkent géndózisa befolyásolja-e a telomerek hosszát. Ennek céljából a 
mutáns heterozigótákból kivont DNS összes HeT-A tartalmát összehasonlítottuk a vad típussal. A kapott eredmény alapján a csökkent mennyiségü Prod, Chromator és a JIL-1 null (z2) allél a vad típusnál valamivel hosszabb telomert okoz, míg a Z4, SUMO, vagy az lwr (Ubc9) mutánsok csökkent fehérje szintje valamint a JIL-1 funkciónyeréses (i3) allélje (amely megemelt kináz aktivitást eredményez) nincs hatással a telomerhosszra (25. ábra). Korábbi kísérletünkben nem találtunk szignifikáns változást két másik prod mutáns $H e T-A$ kópiaszámában az Oregon-R kontrollhoz képest, míg ebben az esetben tapasztalható némi telomerhossz növekedés. Ez betudható annak is, hogy utóbbi esetben jobban törekedtünk a genetikai háttér általi torzítás kiküszöbölésére. Azonban egy szigorú szignifikancia szinttel végzett Bonferroni korrekció után a négy prod mutáns közül csak a prod ${ }^{U}$ null mutáns mutatott szignifikáns növekedést. Tehát eredményeink alapján a két különböző laboratóriumbam vizsgált négy prod allél HeT-A kópiaszámra gyakorolt hatása valódi lehet, azonban gyenge. A Bonferroni korrekció elvégzése után egyik további mutánsban sem tapasztalható szignifikáns telomerhossz növekedés, vagy a megfigyelhető hatás nagyon gyenge, mint az a prod mutánsok esetében lehetséges. Eszerint a kromatin szerkezetében vagy a HTT fehérjék szumoiláltságában bekövetkező változás nem feltétlenül elég a transzpozíciók vagy a génkonverzió gyakoriságának megemeléséhez a telomereken. 


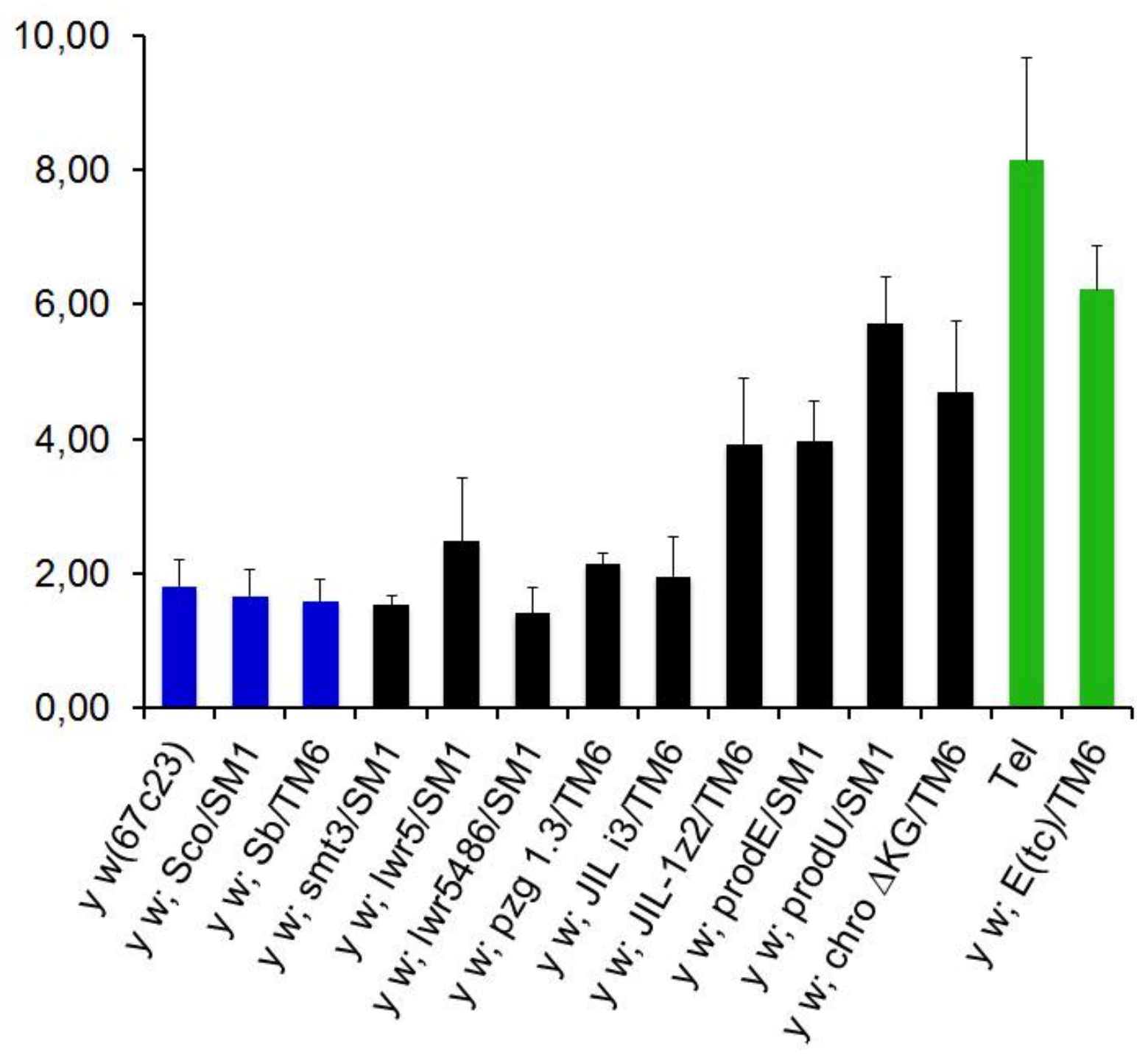

25. ábra. Különböző mutánsok telomerhosszainak összehasonlítása. A grafikon a relatív HeT-A kópiaszámokat (átlagolt $2^{\Delta \mathrm{Ct}}$ értékek) ábrázolja az $\mathrm{S} 17$ riboszómális fehérje (RpS17) kópiaszámához normalizálva. Három különböző napon végzett, napi három párhuzamos mérés eredményeit átlagoltuk. A hibavonalak megismételt kísérletek szórását jelzik. A mutánsokat (a Tel kivételével) heterozigóta formában vizsgáltuk, és mindegyiket standardizált genetikai hátteren tartottuk két évig a vizsgálatot megelőzően, hogy kellő időt biztosítsunk az esetleges telomerhossz változásokhoz. A vad típusú negatív kontrollt a kék oszlopok jelzik, a pozitív kontroll eredményeit (Melnikova és Georgiev, 2002; Siriaco és mtsai., 2002), a zöld oszlopok ábrázolják. 


\section{EREDMÉNYEK MEGVITATÁSA}

\section{$\underline{\text { A HTT kromatinszerkezete }}$}

A telomer három szakasza citológiai, genetikai és molekuláris megközelítéssel is elkülöníthető, mert nyilvánvaló különbség mutatkozik a cap, a HTT sor és a szubtelomerikus TAS repeatek DNS és kromatin szerkezete között (Biessmann és mtsai., 2005a). A TAS szakaszba vagy annak közvetlen közelébe inszertálódott riporter gének expressziója variegáló fenotípust mutat, ellenben a TAS-tól $\sim 11$ kb távolságra, a HTT szakaszba inszertálódott transzgének expressziója már nem mutat variegációt, hanem erösen kifejeződnek (Biessmann és mtsai., 2005b). Ezek az eredmények azt jelzik, hogy a TAS heterokromatikus géncsendesítést okoz, vagyis zárt kromatinszerkezetü, míg a HTT sor nem okoz géncsendesítést, vagyis nyílt, eukromatikus kromatinszerkezete van, amit a citológiai adatok is alátámasztanak (Biessmann és mtsai., 2005a).

Ezeket a következtetéseket saját eredményeink is megerősítik. A HeT-A promóter aktivitását minden bizonnyal alapvetően befolyásolják a retrotranszpozon sorhoz kötődő fehérje komplexek. Az általunk ismertetett Prod mellett korábbi munkák a Z4, és a JIL-1 fehérje jelenlétét mutatták ki a HTT soron (Andreyeva és mtsai., 2005), és saját munkáink alapján ezekhez most már hozzáadhatjuk a Chromator-t, a szumoilációért felelős fehérjéket, valamint TRF2/DREF komplexet és valószínüleg a NURF komplexet is. Az összes említett fehérje a Drosophila genom nagyszámú eukromatikus lókuszán is jelen van, ami arra utal, hogy a HTT soron és az eukromatin egyéb részein ugyanazon fehérje komplexek irányítják a génműködést és szabályozzák a kromatinszerkezetet.

\section{A Prod szerepe a HTT doménen}

A Prod elsődleges hatása a $H e T-A$ szabályozó régióján közvetlen DNS-kötéssel érvényesül, azonban a Prod-HeT-A DNS interakció markánsan eltér a centrikus heterokromatinon leírt Prod-DNS interakciótól. A centromerikus heterokromatinon a Prod igen nagy affinitással kötődik az $1,686 \mathrm{~g} / \mathrm{cm}^{3} 10 \mathrm{bp}$-os szatellitta DNS-hez (Török és mtsai., 2000) (1. ábra), ellenben a Prod-HTT interakció sokkal kisebb affinitású (12. és 13. ábra). 
Még nem ismerjük azt a pontos HeT-A DNS szekvenciát, melyhez a Prod közvetlenül kapcsolódik, de eredményeink azt valószínűsítik, hogy a Prod-HTT interakciót in vivo más kromoszómális fehérjék is stabilizálhatják. Saját adataink alapján ezen interakciós partnerek egyike a Chro-Z4-JIL-1, illetve a Z4 tartalmú DREF komplex lehet.

Az élesztő-kettőshibrid adataink megerősítették azt a korábbi sejtést, hogy a Prod kooperatív kötéssel homomultimereket alkotva kapcsolódhat a DNS-hez. Korábbi biokémiai adataink arra utaltak, hogy a Prod alacsony szekvencia-specifitással számos DNS szekvenciához kötődhet, mely kötődést épp a kooperatív interakciók stabilizálhatják (Török és mtsai., 2000). A centromerikus heterokromatinon a Prod multimerek kitüntetett szerepet játszanak a kromoszóma kondenzációban (Török és mtsai., 1997), ezért elképzelhető, hogy a HTT soron a HeT-A promóter aktivitásának szabályozása is részben a kromatin szerkezet befolyásolásával történik.

A Z4 és a JIL-1 pontos szerepe a telomereken még nem ismert, de az eukromatikus kötőhelyeken az általános kromoszómaszerkezetre kifejtett mutáns fenotípusaik alapján (Deng és mtsai., 2005; Eggert és mtsai., 2004; Wang és mtsai., 2001), valamint biokémiai funkcióik alapján mindkét fehérje részt vehet a HTT szakasz nyílt kromatin konformációjának kialakításában, ami hatással lehet a telomerikus transzpozonok transzkripciójára, a telomerikus génkonverzióra, és befolyásolhatja a TAS géncsendesítő hatásának átterjedését a HTT szakaszra. Valószínüleg egyikük sincs közvetlen hatással a TAS kromatin szerkezetére, mivel a prod, pzg (Z4-et kódoló gén), JIL-1 és chro mutációk nem befolyásolják a TPEvariegáció fenotípusát (Mason és mtsai., 2004).

A telomerhossz szabályozásának egyik lehetséges ellenőrzési pontja a HTT sor HeT-A promóter aktivitásának szabályozása, mert a transzkriptumok kódolják a transzpozícióhoz nélkülözhetetlen GAG fehérjét és reverz transzkriptázt, valamint templátként szolgálnak a reverz transzkriptáz számára a transzpozícióhoz. Promóter aktivitást a HeT-A 3’UTR szakasz utolsó 400-600 bp hosszú részén írtak le, ami nagyjából megfelel a 13. ábrán látható 3. fragmentumnak (Danilevskaya és mtsai., 1997; Kahn és mtsai., 2000). Ez a promóter a tőle downstream elhelyezkedő elem transzkripcióját irányítja (Biessmann és mtsai., 1994; Capkova Frydrychova és mtsai., 2008). A HeT-A elem oligo(A) farkának 504 és 953 bp közötti szakaszára térképezett Prod kötőhely közvetlenül a HeT-A promóter régiótól upstream helyezkedik el, ami valószínüsíti a Prod közvetlen szerepét a HeT-A transzkripció szabályozásában. A prod mutánsokból qRT-PCR-ral kimutatott megemelkedő HeT-A transzkript szint arra utal, hogy a Prod fehérje valóban a HeT-A transzkripció represszora lehet. 
A megemelkedett transzkriptum szint a $\mathrm{prod} / \mathrm{CyO}$ legyek petefészkeiben azonban nem vezet a telomer hosszabbodásához, ellentétben azzal, amit Su(var)205 hetrerozigótákban kimutattak (Savitsky és mtsai., 2002). Ennek oka valószínüleg az, hogy a prod mutánsokban a capping struktúra ép marad, nem úgy, mint a $S u(v a r) 205$ mutánsokban. A politén kromoszómák immunhisztokémiai festésén a Su(var)205 által kódolt HP1 csak a kromoszómavégeken látható (Andreyeva és mtsai., 2005), azonban kromatin immunprecipitációval sikerült a HP1-et a HTT és a TAS doménen is kimutatni (Frydrychova és mtsai., 2008). A Su(var)205 mutánsban megemelkedő HeT-A transzkriptum szint a HP1 HeT-A aktivitásra gyakorolt gátló hatását mutatja (Perrini és mtsai., 2004). A Su(var)205 és a prod mutációk $H e T-A$ transzkripcióra kifejtett hatása azonban eltérő módon érvényesülhet. A HP1 hiánya feltehetően nem a HeT-A promóter aktivitást változtatja meg, hanem a kromatin szerkezetét. A HP1 ugyanis közvetlenül kötődik egy hiszton metil transzferázhoz, ami a hiszton H3 molekulák 9-es pozícióban lévő lizinjét trimetilálja (H3K9me3). Ez, a HTT szakasz mentén is megtalálható $\mathrm{H} 3 \mathrm{~K} 9 \mathrm{me} 3$ módosítás láncreakció-szerüen további HP1 fehérjék megkötődését eredményezi, ami újabb metilációt okozva hoz létre zárt kromatin szerkezetet (Perrini és mtsai., 2004).

A prod és $S u(v a r) 205$ mutációk eltérö hatása a telomerhosszra azt bizonyítja, hogy a HTT kópiaszám szempontjából a capping komplex kromoszómavég védelme egy szigorúbb szabályozást jelent, mint a HeT-A transzkriptum szintje a csíravonalban. Ehhez hasonló jelenséget élesztő és humán telomerek esetén is leírtak, ahol a kromoszómavégeken felépülő fehérje komplexek irányítják a telomeráz hozzáférését a telomerekhez, ezzel szabályozva a telomer hosszabbodását (Chan és Blackburn, 2002; Vega és mtsai., 2003; Wei és Price, 2003).

A Drosophila telomer másik két retroelemén, a TART és TAHRE elemeken nem próbáltunk Prod kötőhelyet térképezni, aminek az a fö oka, hogy a TART elem promóter régiója még nem ismert és a TART mindkét száláról alacsony szintü transzkriptum képződik, vagyis a TART több promóter szakaszt is tartalmazhat (Danilevskaya és mtsai., 1999; Walter és Biessmann, 2004), ami nehezítené az eredmények értelmezését. A TAHRE szekvencia nagyon hasonló a HeT-A eleméhez (kivétel a további RT ORF) (Abad és mtsai., 2004b), de promóter régiót ezidáig még a TAHRE-ban sem azonosítottak. Továbbá a TAHRE transzkriptum szintje valószínüleg elég alacsony lehet, mivel csak egyetlen teljes és két csonka TAHRE kópia van az Oregon-R genomban (Abad és mtsai., 2004b).

A HeT-A promóter aktivitását befolyásolhatja a TAS telomerikus domén is, amely a géncsendesítést okoz. A TAS cisz irányú géncsendesítő hatása versenghet a HTT szakasz génaktivációs hatásaival (Golubovsky és mtsai., 2001; Mason és mtsai., 2000; Mason és 
mtsai., 2003a), ezzel a TAS fontos szerepet játszhat a HeT-A promóter aktivitásának cisz gátlásában, amint azt a TAS közeli $\mathrm{P}$ elem inszerciók részleges gátlása is bizonyítja (Biessmann és mtsai., 2005a). Mint azt fentebb tárgyaltuk, ezt a hatást modulálhatják a HTT doménen jelen lévő fehérjék.

\section{A Prod-Chro interakció szerepe}

Kimutattuk, hogy a Prod és a Chromator fehérjék közvetlen kötődnek egymáshoz, és ez a kötődés alacsony affinitású lehet, mivel csak az összes fehérje mennyiség 1/100-adát érinti. A Chromator ezen kívül közvetlenül kapcsolódik a Z4 cink-ujj fehérjéhez (Eggert és mtsai., 2004) és a H3S10 kináz JIL-1 fehérjéhez is (Rath és mtsai., 2006). A Chromator azonban nem csak mint kromatin alkotórész ismert, hanem szintén része a magorsó mátrixnak (Johansen és Johansen, 2009), ahol kölcsönható partnere egyéb magorsó mátrix fehérjéknek mint a Skeletor és az EAST (Rath és mtsai., 2004). Ezek az eredmények azt valószínűsítik, hogy a Chromator egy adapter fehérje lehet, amely nagyszámú fehérje partnerrel képes interakcióba lépni. A Chromator kölcsönhatásainak egyik jellemző sajátsága, hogy az egyik partner hiánya nem gátolja a másik partner kromoszómális lokalizációját, tehát feltehetően laza, változó összetételü fehérje komplexek része lehet. Példaként a Z4 kromoszómális lokalizációja akkor sem változik, ha a Chromator fehérje kifejeződését RNS interferenciával gátolják, valamint a Z4-et kódoló pzg mutánsokban sem érintett a Chromator lokalizációja (Gortchakov és mtsai., 2005). Ehhez hasonlóan a JIL-1 eloszlása sem változik meg a Chromator RNSi-kezelt sejtkultúrákban vagy Chromator mutációk jelenlétében (Rath és mtsai., 2006).

Eredményeink alapján a Prod-Chromator interakcióra ugyanez mondható el. A legárulkodóbb eredmény ebből a szempontból az eltérő eredetű (genotípusú) X kromoszómális HTT domének eltérő festési mintázata (19. és 20. ábrák). A különböző ProdZ4/Chromator festődési mintázat a különböző eredetü HTT sorokon azt jelzi, hogy a Prod lokalizációja sem feltétlenül függ a Chromator jelenlététől és további fehérje alkotók is részt vehetnek a kölcsönhatásban. A Prod és a Z4/Chromator festési mintázatok a kromoszóma karokon alig fednek át (17. és 18. ábra kettős festések), és a kolokalizációjuk a HTT soron inkább tünik kivételnek, mint szabálynak. Mivel a Prod-Chromator interakció csak néhány lókuszra korlátozódik (ilyen pl. a HTT sor), ez lehet a magyarázata annak, hogy a fehérjéknek csak 1/100-adát sikerült közös komplexben kimutatnunk in vivo. 
A Prod és a Z4/Chromator eltérő lokalizációja eltérő funkciót jelez. A legtöbb Prod fehérje a nagyobb mértékben kondenzálódott bandekben található, ami összhangban van a mutáns fenotípusból következtetett kromatin csomagolásban betöltött szereppel (Török és mtsai., 1997). Ezzel szemben a Chromator, JIL-1, Z4 és Skeletor fehérjék a politén kromoszómák lazábban csomagolt interbandjeiben találhatóak, ahol közös funkciójuk a nyílt kromatin szerkezet fenntartása lehet, és ezt mutáns fenotípusaik is megerősítik (Bao és mtsai., 2007; Deng és mtsai., 2005; Rath és mtsai., 2006). A chro és prod heterozigóta mutánsokban mért meghosszabbodott telomerek (25. ábra) azonban azt jelzik, hogy a HTT soron mindkét fehérje részt vesz a retrotranszpozíció és/vagy a homológ rekombináció gátlásában, feltehetően egy represszív kromatin struktúra kialakításával. A HTT szabályozás kivételesen érzékeny lehet a prod dózisra, mivel a hipomorf $\operatorname{prod}^{E}$ mutáció is hosszabb telomert eredményez.

Ezek az ellentmondásos adatok úgy egyeztethetők össze, ha azt feltételezzük, hogy hogy a Prod és Chromator fehérjék a HTT soron olyan alternatív komplexek tagjai lehetnek, melyek akár ellentétes funkciókat láthatnak el. Ennél fogva a Prod tartalmú Chromator komplex ellenkező szerepet játszhat a kromatin szerkezet szabályozásában, mint a Prodmentes komplex. A Chromator képes lehet a Prod-dal együttmüködve represszor komplexet alkotni - és ez magyarázhatja a prod és chro mutánsokban mért hosszabb telomereket -, de a Chro egy alternatív komplexnek is tagja lehet, amikor a Z4-en keresztül a TRF2/DREF és NURF komplexszel nyíltabb kromatin konformációt hoz létre. A NURF komplex négy tagjából három része a Z4 tartalmú TRF2/DREF komplexnek is, ami sejtosztódásban szerepet játszó gének transzkripcióját irányítja, mint promóter felismerő faktor (Hochheimer és Tjian, 2003). A DREF interband régiók százaihoz kötődik a politén kromoszómán (Hirose és mtsai., 2002), ami szinte tökéletesen átfed a Z4 lokalizációjával (21. ábra). Ez felveti a lehetőségét a TRF2/DREF komplex jelenlétének a HTT doménen, és ez a komplex a NURF komplexszel összehangoltan elsődleges szereppel bírhat az eukromatin-szerü szerkezet kialakításában (Biessmann és mtsai., 2005b). Nem tudjuk, hogy ez a komplex mihez kötődik, mivel a HTT elemekben nincs meg az 5'-TATCGATA-3' DREF target szekvencia (Matsukage és mtsai., 2008). Elképzelhető, hogy itt a cink-ujj doménnel rendelkező Z4 felelős a komplex kihorgonyzásáért. 


\section{$\underline{\text { A szumoiláció szerepe a HTT domén müködésében }}$}

A szumoiláció szabályozhatja a fehérjék funkcióját és lokalizációját, valamint a fehérje komplexek összeszerelődését (Yeh, 2009), továbbá a szumoilációt gyakran kapcsolják össze a transzkripció repressziójával. A hisztonok szumoilációja represszált kromatint jelez (Shiio és Eisenman, 2003), és bizonyos transzkripciót szabályozó fehérjék szumoilációja hiszton deacetilázhoz való kapcsolódást eredményezhet, ami a kromatinról a hiszton acetilációs jelek eltávolításával a transzkripció gátlását okozza (Yang és Sharrocks, 2004). Ennélfogva a szumoiláció a Prod és a HP1 fehérjékkel együtt a HTT transzkripcionális inaktivációjáért lehetnek felelősek, vagy egyfajta kapcsolóként müködhetnek az alternatív kromatin állapotok közt.

Még nem ismert, hogy mely HTT-kötő fehérjék lehetnek szumoiláltak. A Prod, Chromator és JIL-1 is tartalmaz 2-3 magas valószínüségű szumoilációs helyet, míg a Z4 egyet sem. Említésre méltó azonban, hogy a Windei fehérje, ami a dSETDB1/Eggless nevü H3K9 metil transzferáz kofaktoraként ismert (Koch és mtsai., 2009), erős kölcsönható partnere a Prod-nak (2. táblázat). Bár sem a Windei, sem az Eggless telomerikus jelenléte nincs bizonyítva, de Drosophila nőstény csíravonalban - ahol a HTT retrotranszpozonok aktívak az egyetlen esszenciális H3K9 metiltranszferáz az Eggless, amely a H3K9 trimetilációhoz szükséges ecetmuslicában (Yoon és mtsai., 2008). A létfontosságú telomerikus alkotóelem, a HP1, pedig épp ahhoz a H3K9 módosításhoz tud kapcsolódni, amit az Eggless hoz létre, tehát a Windei-Eggless jelenléte a HTT soron igen valószínü. Az Egglessről korábban kimutatták, hogy erősen szumoilált (Koch és mtsai., 2009), vagyis aktivitása a szumoiláció függvénye. Ebböl elméletileg az következik, hogy az Eggless szumoliációjának szintje megszabhatja a HTT kromatin szerkezetét.

Emellett bármely TRF2/DREF alkotó fehérje szumoilációja jelentős hatással lehet a HTT kromatin struktúrájára. Elképzelhető, hogy a Prod és egyéb represszorok versengenek a Z4 fehérjét is tartalmazó DREF komplexszel HTT kötőhelyekért hasonló módon, ahogyan azt a boundary element-associated factor (BEAF) esetében leírták (Hart és mtsai., 1999). Az egyes fehérjék szumoilációs szintje pedig átbillentheti a kötődés affinitását és ezzel a kromatin állapotát egyik alternatív állapotból a másikba.

Mindazonáltal méréseink alapján az smt3 vagy a $l w r$ lecsökkent dózisa nincs különösebb hatással a telomer hosszára (24. ábra). Ebből azonban nem következik, hogy a HTT fehérjéinek szumoilációja nem lenne fontos a HTT müködéséhez, mert könnyen lehet, hogy a heterozigótákban felére csökkent smt3 és $l w r$ génaktivitás még a telomerhossz 
szabályozásához szükséges határérték felett marad. Ez utóbbi lehetőséget támasztja alá az a tény is, hogy az smt3 és lwr mutációk együttes jelenlétére volt szükség ahhoz, hogy szuppresszálni lehessen a mod $(\operatorname{mdg} 4)$ mutáció hatását a gypsy transzpozon által okozott fenotípusra (Capelson és Corces, 2006). A fenti kísérletekben a gypsy insulator hatása yellow, white és cut fenotípusok megjelenését okozza, ami nyílvánvalóan sokkal érzékenyebb fenotípus, mint az általunk qPCR-el mért HTT hossz. Ez alapján nem lehet messzemenő következtetéseket levonni abból, hogy mi az egyszeres mutánsokban, egy kevéssé érzékeny rendszerrel nem tudtunk fenotípust kimutatni.

A JIL-1 kináz telomerikus müködése a szumoilációnál és a pzg esetében tapasztaltaknál jóval inkább dózisfüggő lehet, mert a $J I L-1^{z 2}$ null allél heterozigótáiban a $J I L$ 1 aktivitás feleződése elég a telomerhossz szabályozás megzavarására, ami hosszabbodott telomerekben jelentkezik (25. ábra). A C-terminálisan csonkolt fehérjét kódoló hipomorf JIL$1^{3}$ allél (Ebert és mtsai., 2004) azonban nem változtatja a telomerhossz homeosztázist (24. ábra), ami összhangban van azon adatokkal, hogy ezen mutánsokban a kromoszóma morfológiája, és a hiszton metilációs mintázat is normális marad (Zhang és mtsai., 2006).

Savitsky és mtsai. eredményei arra utalnak, hogy a Drosophila telomerek hosszát egy RNSi-alapú mechanizmus is szabályozhatja, mert az RNSi útvonalban résztvevő spn-E (RNS helikáz), vagy aub (Argonaute család) mutációja esetén a csíravonalban megemelkedik a $T A R T$, és kismértékben a HeT-A transzkriptum szintje (Savitsky és mtsai., 2006). Ez százszorosára emeli a TART transzpozíciók számát, de nincs hatással a HeT-A transzpozíciók gyakoriságára. Eddigi ismereteink alapján nem tudjuk, hogy az RNSi mechanizmus befolyásolja-e a HTT-n lokalizálódó proteinek müködését.

A 26. ábrán összefoglaltuk a Drosophila telomerek HTT doménjén leírt összes fehérjét, és az eddig ismert adatok alapján megpróbáltuk ábrázolni azok legvalószínűbb müködési modelljét. Az ábrán feltüntettük az összes ismert fehérje interakciót.

A HTT domén fehérje interakciónak központi mediátora a Chromator lehet, amely közvetlenül kölcsönhat a Prod, a JIL-1 és Z4 fehérjékkel. A Z4 a DREF komplex része lehet, a Prod pedig multimerként specifikusan kötődik a $\mathrm{HeT}-\mathrm{A}$ promótert közvetlenül megelőző szakaszhoz. A Prod horgonyozhatja ki a szumoilációs komplexet, és ezzel módosíthatja a különböző komplex alkotók kötési sajátosságait. A szumoilált Eggless (nincs feltüntetve) metilálja a H3 hisztont a 9. pozícióban lévő lizinjén, mely módosítást felismerve kötődik ide a HP1 és gátolja a transzkripciót. 


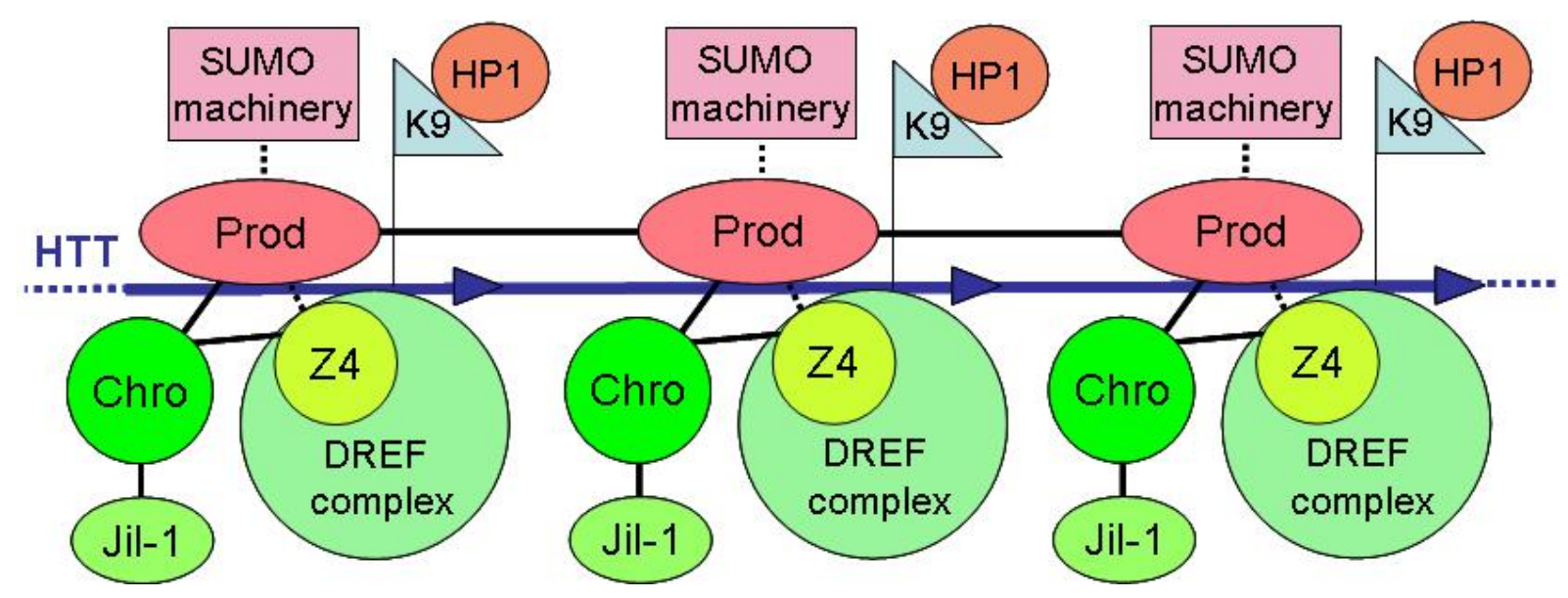

26. ábra. Az ismert HTT doménhez kötődő fehérjék és azok lehetséges interakcióit összefoglaló modell. A vastag fekete vonal az igazolt fehérje-fehérje kölcsönhatásokat jelzi, a szaggatott a feltételezett interakciókat. A kék vonal a DNS-t, a nyilak pedig az egyedi retrotranszpozonokat szemléltetik. A zöldes színnel feltüntetett fehérjék a nyílt, míg a pirosas színüek a zárt kromatinszerkezet kialakításában vesznek részt. A Prod multimerként kötődik a $H e T-A$ promóter régiójához és a szumoilációs enzimeket a komplexben lévő fehérjékhez irányíthatja. A Chromator mediátor fehérjeként müködhet a Prod, JIL-1 és Z4 (DREF komplex) közötti kölcsönhatásokban, de egyéb interakciók sem zárhatóak ki. A HP1 valószínűleg a szumoilált Eggless által metilált H3K9 hisztonmódosuláshoz kötődve gátolja a retrotranszpozonok transzkripcióját. 


\section{KÖSZÖNETNYILVÁNÍTÁS}

Szeretném megköszönni témavezetőmnek, Dr. Török Tibornak, hogy a csoportjában dolgozhattam és szakmai vezetésével elsajátíthattam számos genetikai és molekuláris biológiai módszert. Hálásan köszönöm a rengeteg tanácsot és a dolgozat megírásában nyújtott nélkülözhetetlen segítséget. Köszönettel tartozom a Genetikai Tanszék és az SZBK Genetikai Intézet Rovargenetikai csoportok tagjainak, hogy munkám segítőkész és kellemes légkörben végezhettem.

Köszönettel tartozom Dr. Harald Biessmann ${ }^{\dagger}$ és Dr. James M. Mason kutatócsoportjainak a qPCR kísérletek elvégzésében, valamint Dr. Deák Péternek és Dr. Pál Margitnak az élesztő két-hibrid munkákban nyújtott segítségért.

Nagyon köszönöm családomnak a támogatást és a nyugodt háttér biztosítotását tanulmányaim és munkám évei során. 


\section{IRODALOMJEGYZÉK}

Abad, J.P., De Pablos, B., Osoegawa, K., De Jong, P.J., Martin-Gallardo, A., és Villasante, A. (2004a). Genomic analysis of Drosophila melanogaster telomeres: full-length copies of HeTA and TART elements at telomeres. Mol Biol Evol 21, 1613-1619.

Abad, J.P., De Pablos, B., Osoegawa, K., De Jong, P.J., Martin-Gallardo, A., és Villasante, A. (2004b). TAHRE, a novel telomeric retrotransposon from Drosophila melanogaster, reveals the origin of Drosophila telomeres. Mol Biol Evol 21, 1620-1624.

Andreyeva, E.N., Belyaeva, E.S., Semeshin, V.F., Pokholkova, G.V., és Zhimulev, I.F. (2005). Three distinct chromatin domains in telomere ends of polytene chromosomes in Drosophila melanogaster Tel mutants. J Cell Sci 118, 5465-5477.

Arkhipova, I.R., és Morrison, H.G. (2001). Three retrotransposon families in the genome of Giardia lamblia: two telomeric, one dead. Proc Natl Acad Sci U S A 98, 14497-14502.

Badenhorst, P., Voas, M., Rebay, I., és Wu, C. (2002). Biological functions of the ISWI chromatin remodeling complex NURF. Genes Dev 16, 3186-3198.

Bao, X., Deng, H., Johansen, J., Girton, J., és Johansen, K.M. (2007). Loss-of-function alleles of the JIL-1 histone H3S10 kinase enhance position-effect variegation at pericentric sites in Drosophila heterochromatin. Genetics 176, 1355-1358.

Bi, X., Srikanta, D., Fanti, L., Pimpinelli, S., Badugu, R., Kellum, R., és Rong, Y.S. (2005). Drosophila ATM and ATR checkpoint kinases control partially redundant pathways for telomere maintenance. Proc Natl Acad Sci U S A 102, 15167-15172.

Bi, X., Wei, S.C., és Rong, Y.S. (2004). Telomere protection without a telomerase; the role of ATM and Mre11 in Drosophila telomere maintenance. Curr Biol 14, 1348-1353.

Biessmann, H., Carter, S.B., és Mason, J.M. (1990). Chromosome ends in Drosophila without telomeric DNA sequences. Proc Natl Acad Sci U S A 87, 1758-1761.

Biessmann, H., Champion, L.E., O'Hair, M., Ikenaga, K., Kasravi, B., és Mason, J.M. (1992a). Frequent transpositions of Drosophila melanogaster HeT-A transposable elements to receding chromosome ends. EMBO J 11, 4459-4469.

Biessmann, H., Kasravi, B., Bui, T., Fujiwara, G., Champion, L.E., és Mason, J.M. (1994). Comparison of two active HeT-A retroposons of Drosophila melanogaster. Chromosoma 103, 90-98. 
Biessmann, H., Kasravi, B., Jakes, K., Bui, T., Ikenaga, K., és Mason, J.M. (1993). The genomic organization of HeT-A retroposons in Drosophila melanogaster. Chromosoma 102, 297-305.

Biessmann, H., és Mason, J.M. (1988). Progressive loss of DNA sequences from terminal chromosome deficiencies in Drosophila melanogaster. EMBO J 7, 1081-1086.

Biessmann, H., Prasad, S., Semeshin, V.F., Andreyeva, E.N., Nguyen, Q., Walter, M.F., és Mason, J.M. (2005a). Two distinct domains in Drosophila melanogaster telomeres. Genetics $171,1767-1777$.

Biessmann, H., Prasad, S., Walter, M.F., és Mason, J.M. (2005b). Euchromatic and heterochromatic domains at Drosophila telomeres. Biochem Cell Biol 83, 477-485.

Biessmann, H., Valgeirsdottir, K., Lofsky, A., Chin, C., Ginther, B., Levis, R.W., és Pardue, M.L. (1992b). HeT-A, a transposable element specifically involved in "healing" broken chromosome ends in Drosophila melanogaster. Mol Cell Biol 12, 3910-3918.

Biessmann, H., Walter, M.F., és Mason, J.M. (1997). Drosophila telomere elongation. Ciba Found Symp 211, 53-67; discussion 67-70.

Biggin, M.D. (1999). Ultraviolet cross-linking assay to measure sequence-specific DNA binding in vivo. Methods Enzymol 304, 496-515.

Boivin, A., Gally, C., Netter, S., Anxolabehere, D., és Ronsseray, S. (2003). Telomeric associated sequences of Drosophila recruit polycomb-group proteins in vivo and can induce pairing-sensitive repression. Genetics 164, 195-208.

Capelson, M., és Corces, V.G. (2006). SUMO conjugation attenuates the activity of the gypsy chromatin insulator. EMBO J 25, 1906-1914.

Capkova Frydrychova, R., Biessmann, H., és Mason, J.M. (2008). Regulation of telomere length in Drosophila. Cytogenet Genome Res 122, 356-364.

Cenci, G., Ciapponi, L., és Gatti, M. (2005). The mechanism of telomere protection: a comparison between Drosophila and humans. Chromosoma 114, 135-145.

Cenci, G., Siriaco, G., Raffa, G.D., Kellum, R., és Gatti, M. (2003). The Drosophila HOAP protein is required for telomere capping. Nat Cell Biol 5, 82-84.

Chan, S.W., és Blackburn, E.H. (2002). New ways not to make ends meet: telomerase, DNA damage proteins and heterochromatin. Oncogene 21, 553-563.

Ciapponi, L., Cenci, G., Ducau, J., Flores, C., Johnson-Schlitz, D., Gorski, M.M., Engels, W.R., és Gatti, M. (2004). The Drosophila Mre11/Rad50 complex is required to prevent both telomeric fusion and chromosome breakage. Curr Biol 14, 1360-1366. 
Cryderman, D.E., Morris, E.J., Biessmann, H., Elgin, S.C., és Wallrath, L.L. (1999). Silencing at Drosophila telomeres: nuclear organization and chromatin structure play critical roles. EMBO J 18, 3724-3735.

Csink, A.K., és Henikoff, S. (1998). Something from nothing: the evolution and utility of satellite repeats. Trends Genet 14, 200-204.

Danilevskaya, O.N., Arkhipova, I.R., Traverse, K.L., és Pardue, M.L. (1997). Promoting in tandem: the promoter for telomere transposon HeT-A and implications for the evolution of retroviral LTRs. Cell 88, 647-655.

Danilevskaya, O.N., Traverse, K.L., Hogan, N.C., DeBaryshe, P.G., és Pardue, M.L. (1999). The two Drosophila telomeric transposable elements have very different patterns of transcription. Mol Cell Biol 19, 873-881.

Deng, H., Zhang, W., Bao, X., Martin, J.N., Girton, J., Johansen, J., és Johansen, K.M. (2005). The JIL-1 kinase regulates the structure of Drosophila polytene chromosomes. Chromosoma 114, 173-182.

Ebert, A., Schotta, G., Lein, S., Kubicek, S., Krauss, V., Jenuwein, T., és Reuter, G. (2004). $\mathrm{Su}$ (var) genes regulate the balance between euchromatin and heterochromatin in Drosophila. Genes Dev 18, 2973-2983.

Eggert, H., Gortchakov, A., és Saumweber, H. (2004). Identification of the Drosophila interband-specific protein Z4 as a DNA-binding zinc-finger protein determining chromosomal structure. J Cell Sci 117, 4253-4264.

Eissenberg, J.C., James, T.C., Foster-Hartnett, D.M., Hartnett, T., Ngan, V., és Elgin, S.C. (1990). Mutation in a heterochromatin-specific chromosomal protein is associated with suppression of position-effect variegation in Drosophila melanogaster. Proc Natl Acad Sci U S A 87, 9923-9927.

Eissenberg, J.C., Morris, G.D., Reuter, G., és Hartnett, T. (1992). The heterochromatinassociated protein HP-1 is an essential protein in Drosophila with dosage-dependent effects on position-effect variegation. Genetics 131, 345-352.

Fanti, L., Giovinazzo, G., Berloco, M., és Pimpinelli, S. (1998). The heterochromatin protein 1 prevents telomere fusions in Drosophila. Mol Cell 2, 527-538.

Fanti, L., és Pimpinelli, S. (2008). HP1: a functionally multifaceted protein. Curr Opin Genet Dev 18, 169-174.

Frydrychova, R.C., Mason, J.M., és Archer, T.K. (2008). HP1 is distributed within distinct chromatin domains at Drosophila telomeres. Genetics 180, 121-131. 
Gao, G., Walser, J.C., Beaucher, M.L., Morciano, P., Wesolowska, N., Chen, J., és Rong, Y.S. (2010). HipHop interacts with HOAP and HP1 to protect Drosophila telomeres in a sequence-independent manner. EMBO J 29, 819-829.

George, J.A., DeBaryshe, P.G., Traverse, K.L., Celniker, S.E., és Pardue, M.L. (2006). Genomic organization of the Drosophila telomere retrotransposable elements. Genome Res $16,1231-1240$.

Golubovsky, M.D., Konev, A.Y., Walter, M.F., Biessmann, H., és Mason, J.M. (2001). Terminal retrotransposons activate a subtelomeric white transgene at the $2 \mathrm{~L}$ telomere in Drosophila. Genetics 158, 1111-1123.

Gortchakov, A.A., Eggert, H., Gan, M., Mattow, J., Zhimulev, I.F., és Saumweber, H. (2005). Chriz, a chromodomain protein specific for the interbands of Drosophila melanogaster polytene chromosomes. Chromosoma 114, 54-66.

Hart, C.M., Cuvier, O., és Laemmli, U.K. (1999). Evidence for an antagonistic relationship between the boundary element-associated factor BEAF and the transcription factor DREF. Chromosoma 108, 375-383.

Hirose, F., Ohshima, N., Kwon, E.J., Yoshida, H., és Yamaguchi, M. (2002). Drosophila Mi-2 negatively regulates dDREF by inhibiting its DNA-binding activity. Mol Cell Biol 22, 51825193.

Hochheimer, A., és Tjian, R. (2003). Diversified transcription initiation complexes expand promoter selectivity and tissue-specific gene expression. Genes Dev 17, 1309-1320.

Hochheimer, A., Zhou, S., Zheng, S., Holmes, M.C., és Tjian, R. (2002). TRF2 associates with DREF and directs promoter-selective gene expression in Drosophila. Nature 420, 439445.

Hoskins, R.A., Nelson, C.R., Berman, B.P., Laverty, T.R., George, R.A., Ciesiolka, L., Naeemuddin, M., Arenson, A.D., Durbin, J., David, R.G., és mtsai. (2000). A BAC-based physical map of the major autosomes of Drosophila melanogaster. Science 287, 2271-2274.

Johansen, J., és Johansen, K.M. (2009). The spindle matrix through the cell cycle in Drosophila. Fly (Austin) 3, 213-220.

Kahn, T., Savitsky, M., és Georgiev, P. (2000). Attachment of HeT-A sequences to chromosomal termini in Drosophila melanogaster may occur by different mechanisms. Mol Cell Biol 20, 7634-7642.

Karpen, G.H., és Spradling, A.C. (1992). Analysis of subtelomeric heterochromatin in the Drosophila minichromosome Dp1187 by single P element insertional mutagenesis. Genetics $132,737-753$. 
Koch, C.M., Honemann-Capito, M., Egger-Adam, D., és Wodarz, A. (2009). Windei, the Drosophila homolog of mAM/MCAF1, is an essential cofactor of the H3K9 methyl transferase dSETDB1/Eggless in germ line development. PLoS Genet 5, e1000644.

Komonyi, O., Schauer, T., Papai, G., Deak, P., és Boros, I.M. (2009). A product of the bicistronic Drosophila melanogaster gene CG31241, which also encodes a trimethylguanosine synthase, plays a role in telomere protection. J Cell Sci 122, 769-774.

Kugler, S.J., és Nagel, A.C. (2007). putzig is required for cell proliferation and regulates notch activity in Drosophila. Mol Biol Cell 18, 3733-3740.

Kugler, S.J., és Nagel, A.C. (2010). A novel Pzg-NURF complex regulates Notch target gene activity. Mol Biol Cell 21, 3443-3448.

Levis, R.W., Ganesan, R., Houtchens, K., Tolar, L.A., és Sheen, F.M. (1993). Transposons in place of telomeric repeats at a Drosophila telomere. Cell 75, 1083-1093.

Lohe, A.R., és Brutlag, D.L. (1986). Multiplicity of satellite DNA sequences in Drosophila melanogaster. Proc Natl Acad Sci U S A 83, 696-700.

Maniatis, T., Fritsch, E.F., és Sambrook, J. (1982). Molecular cloning : a laboratory manual (Cold Spring Harbor, N.Y.: Cold Spring Harbor Laboratory).

Mason, J.M., és Biessmann, H. (1995). The unusual telomeres of Drosophila. Trends Genet $11,58-62$.

Mason, J.M., Frydrychova, R.C., és Biessmann, H. (2008). Drosophila telomeres: an exception providing new insights. Bioessays 30, 25-37.

Mason, J.M., Haoudi, A., Konev, A.Y., Kurenova, E., Walter, M.F., és Biessmann, H. (2000). Control of telomere elongation and telomeric silencing in Drosophila melanogaster. Genetica 109, 61-70.

Mason, J.M., Konev, A.Y., és Biessmann, H. (2003a). Telomeric position effect in drosophila melanogaster reflects a telomere length control mechanism. Genetica 117, 319-325.

Mason, J.M., Konev, A.Y., Golubovsky, M.D., és Biessmann, H. (2003b). Cis- and transacting influences on telomeric position effect in Drosophila melanogaster detected with a subterminal transgene. Genetics 163, 917-930.

Mason, J.M., Ransom, J., és Konev, A.Y. (2004). A deficiency screen for dominant suppressors of telomeric silencing in Drosophila. Genetics 168, 1353-1370.

Mason, J.M., Strobel, E., és Green, M.M. (1984). mu-2: mutator gene in Drosophila that potentiates the induction of terminal deficiencies. Proc Natl Acad Sci U S A 81, 6090-6094. 
Matsukage, A., Hirose, F., Yoo, M.A., és Yamaguchi, M. (2008). The DRE/DREF transcriptional regulatory system: a master key for cell proliferation. Biochim Biophys Acta 1779, 81-89.

Maxwell, P.H., Belote, J.M., és Levis, R.W. (2006). Identification of multiple transcription initiation, polyadenylation, and splice sites in the Drosophila melanogaster TART family of telomeric retrotransposons. Nucleic Acids Res 34, 5498-5507.

Melnikova, L., Biessmann, H., és Georgiev, P. (2005). The Ku protein complex is involved in length regulation of Drosophila telomeres. Genetics 170, 221-235.

Melnikova, L., és Georgiev, P. (2002). Enhancer of terminal gene conversion, a new mutation in Drosophila melanogaster that induces telomere elongation by gene conversion. Genetics 162, 1301-1312.

Muller, S., Berger, M., Lehembre, F., Seeler, J.S., Haupt, Y., és Dejean, A. (2000). c-Jun and p53 activity is modulated by SUMO-1 modification. J Biol Chem 275, 13321-13329.

Orlando, V., Strutt, H., és Paro, R. (1997). Analysis of chromatin structure by in vivo formaldehyde cross-linking. Methods 11, 205-214.

Papai, G., Komonyi, O., Toth, Z., Pankotai, T., Muratoglu, S., Udvardy, A., és Boros, I. (2005). Intimate relationship between the genes of two transcriptional coactivators, ADA2a and PIMT, of Drosophila. Gene 348, 13-23.

Pardue, M.L., Danilevskaya, O.N., Lowenhaupt, K., Wong, J., és Erby, K. (1996). The gag coding region of the Drosophila telomeric retrotransposon, HeT-A, has an internal frame shift and a length polymorphic region. J Mol Evol 43, 572-583.

Pardue, M.L., és DeBaryshe, P.G. (2003). Retrotransposons provide an evolutionarily robust non-telomerase mechanism to maintain telomeres. Annu Rev Genet 37, 485-511.

Perrini, B., Piacentini, L., Fanti, L., Altieri, F., Chichiarelli, S., Berloco, M., Turano, C., Ferraro, A., és Pimpinelli, S. (2004). HP1 controls telomere capping, telomere elongation, and telomere silencing by two different mechanisms in Drosophila. Mol Cell 15, 467-476.

Platero, J.S., Csink, A.K., Quintanilla, A., és Henikoff, S. (1998). Changes in chromosomal localization of heterochromatin-binding proteins during the cell cycle in Drosophila. J Cell Biol 140, 1297-1306.

Pryde, F.E., Gorham, H.C., és Louis, E.J. (1997). Chromosome ends: all the same under their caps. Curr Opin Genet Dev 7, 822-828.

Raff, J.W., Kellum, R., és Alberts, B. (1994). The Drosophila GAGA transcription factor is associated with specific regions of heterochromatin throughout the cell cycle. EMBO J 13, 5977-5983. 
Raffa, G.D., Cenci, G., Siriaco, G., Goldberg, M.L., és Gatti, M. (2005). The putative Drosophila transcription factor woc is required to prevent telomeric fusions. Mol Cell 20, 821-831.

Raffa, G.D., Raimondo, D., Sorino, C., Cugusi, S., Cenci, G., Cacchione, S., Gatti, M., és Ciapponi, L. (2010). Verrocchio, a Drosophila OB fold-containing protein, is a component of the terminin telomere-capping complex. Genes Dev 24, 1596-1601.

Raffa, G.D., Siriaco, G., Cugusi, S., Ciapponi, L., Cenci, G., Wojcik, E., és Gatti, M. (2009). The Drosophila modigliani (moi) gene encodes a HOAP-interacting protein required for telomere protection. Proc Natl Acad Sci U S A 106, 2271-2276.

Rashkova, S., Karam, S.E., Kellum, R., és Pardue, M.L. (2002a). Gag proteins of the two Drosophila telomeric retrotransposons are targeted to chromosome ends. J Cell Biol 159, 397402.

Rashkova, S., Karam, S.E., és Pardue, M.L. (2002b). Element-specific localization of Drosophila retrotransposon Gag proteins occurs in both nucleus and cytoplasm. Proc Natl Acad Sci U S A 99, 3621-3626.

Rath, U., Ding, Y., Deng, H., Qi, H., Bao, X., Zhang, W., Girton, J., Johansen, J., és Johansen, K.M. (2006). The chromodomain protein, Chromator, interacts with JIL-1 kinase and regulates the structure of Drosophila polytene chromosomes. J Cell Sci 119, 2332-2341.

Rath, U., Wang, D., Ding, Y., Xu, Y.Z., Qi, H., Blacketer, M.J., Girton, J., Johansen, J., és Johansen, K.M. (2004). Chromator, a novel and essential chromodomain protein interacts directly with the putative spindle matrix protein skeletor. J Cell Biochem 93, 1033-1047.

Ringrose, L., Rehmsmeier, M., Dura, J.M., és Paro, R. (2003). Genome-wide prediction of Polycomb/Trithorax response elements in Drosophila melanogaster. Dev Cell 5, 759-771.

Sampson, D.A., Wang, M., és Matunis, M.J. (2001). The small ubiquitin-like modifier-1 (SUMO-1) consensus sequence mediates Ubc9 binding and is essential for SUMO-1 modification. J Biol Chem 276, 21664-21669.

Saumweber, H., Symmons, P., Kabisch, R., Will, H., és Bonhoeffer, F. (1980). Monoclonal antibodies against chromosomal proteins of Drosophila melanogaster: establishment of antibody producing cell lines and partial characterization of corresponding antigens. Chromosoma 80, 253-275.

Savitsky, M., Kravchuk, O., Melnikova, L., és Georgiev, P. (2002). Heterochromatin protein 1 is involved in control of telomere elongation in Drosophila melanogaster. Mol Cell Biol 22, 3204-3218.

Savitsky, M., Kwon, D., Georgiev, P., Kalmykova, A., és Gvozdev, V. (2006). Telomere elongation is under the control of the RNAi-based mechanism in the Drosophila germline. Genes Dev 20, 345-354. 
Schoeftner, S., és Blasco, M.A. (2009). A 'higher order' of telomere regulation: telomere heterochromatin and telomeric RNAs. EMBO J 28, 2323-2336.

Shareef, M.M., King, C., Damaj, M., Badagu, R., Huang, D.W., és Kellum, R. (2001). Drosophila heterochromatin protein 1 (HP1)/origin recognition complex (ORC) protein is associated with HP1 and ORC and functions in heterochromatin-induced silencing. Mol Biol Cell 12, 1671-1685.

Sheen, F.M., és Levis, R.W. (1994). Transposition of the LINE-like retrotransposon TART to Drosophila chromosome termini. Proc Natl Acad Sci U S A 91, 12510-12514.

Shiio, Y., és Eisenman, R.N. (2003). Histone sumoylation is associated with transcriptional repression. Proc Natl Acad Sci U S A 100, 13225-13230.

Siriaco, G.M., Cenci, G., Haoudi, A., Champion, L.E., Zhou, C., Gatti, M., és Mason, J.M. (2002). Telomere elongation (Tel), a new mutation in Drosophila melanogaster that produces long telomeres. Genetics 160, 235-245.

Talamillo, A., Sanchez, J., és Barrio, R. (2008a). Functional analysis of the SUMOylation pathway in Drosophila. Biochem Soc Trans 36, 868-873.

Talamillo, A., Sanchez, J., Cantera, R., Perez, C., Martin, D., Caminero, E., és Barrio, R. (2008b). Smt3 is required for Drosophila melanogaster metamorphosis. Development 135, $1659-1668$.

Török, T., Benitez, C., Takacs, S., és Biessmann, H. (2007). The protein encoded by the gene proliferation disrupter (prod) is associated with the telomeric retrotransposon array in Drosophila melanogaster. Chromosoma 116, 185-195.

Török, T., Gorjanacz, M., Bryant, P.J., és Kiss, I. (2000). Prod is a novel DNA-binding protein that binds to the $1.686 \mathrm{~g} / \mathrm{cm}(3) 10 \mathrm{bp}$ satellite repeat of Drosophila melanogaster. Nucleic Acids Res 28, 3551-3557.

Török, T., Harvie, P.D., Buratovich, M., és Bryant, P.J. (1997). The product of proliferation disrupter is concentrated at centromeres and required for mitotic chromosome condensation and cell proliferation in Drosophila. Genes Dev 11, 213-225.

Vega, L.R., Mateyak, M.K., és Zakian, V.A. (2003). Getting to the end: telomerase access in yeast and humans. Nat Rev Mol Cell Biol 4, 948-959.

Walter, M.F., és Biessmann, H. (2004). Expression of the telomeric retrotransposon HeT-A in Drosophila melanogaster is correlated with cell proliferation. Dev Genes Evol 214, 211-219.

Walter, M.F., Biessmann, M.R., Benitez, C., Torok, T., Mason, J.M., és Biessmann, H. (2007). Effects of telomere length in Drosophila melanogaster on life span, fecundity, and fertility. Chromosoma 116, 41-51. 
Walter, M.F., Jang, C., Kasravi, B., Donath, J., Mechler, B.M., Mason, J.M., és Biessmann, H. (1995). DNA organization and polymorphism of a wild-type Drosophila telomere region. Chromosoma 104, 229-241.

Wang, Y., Zhang, W., Jin, Y., Johansen, J., és Johansen, K.M. (2001). The JIL-1 tandem kinase mediates histone $\mathrm{H} 3$ phosphorylation and is required for maintenance of chromatin structure in Drosophila. Cell 105, 433-443.

Wei, C., és Price, M. (2003). Protecting the terminus: t-loops and telomere end-binding proteins. Cell Mol Life Sci 60, 2283-2294.

Wilkinson, K.A., és Henley, J.M. (2010). Mechanisms, regulation and consequences of protein SUMOylation. Biochem J 428, 133-145.

Yang, S.H., és Sharrocks, A.D. (2004). SUMO promotes HDAC-mediated transcriptional repression. Mol Cell 13, 611-617.

Yeh, E.T. (2009). SUMOylation and De-SUMOylation: wrestling with life's processes. J Biol Chem 284, 8223-8227.

Yoon, J., Lee, K.S., Park, J.S., Yu, K., Paik, S.G., és Kang, Y.K. (2008). dSETDB1 and SU(VAR)3-9 sequentially function during germline-stem cell differentiation in Drosophila melanogaster. PLoS One 3, e2234.

Zhang, W., Deng, H., Bao, X., Lerach, S., Girton, J., Johansen, J., és Johansen, K.M. (2006). The JIL-1 histone H3S10 kinase regulates dimethyl H3K9 modifications and heterochromatic spreading in Drosophila. Development 133, 229-235.

Zhao, J. (2007). Sumoylation regulates diverse biological processes. Cell Mol Life Sci 64, 3017-3033. 


\section{ÖSSZEFOGLALÁS}

Az ecetmuslica proliferation disrupter (prod) génje egy 346 aminosavból álló DNSkötő kromoszómális fehérjét kódol, mely megtalálható a második és harmadik kromoszómák centromer környéki heterokromatinján, több száz eukromatikus lókuszon, valamint az összes telomeren. A Prod fehérje erősen kötődik a második és harmadik kromoszómák centromerét határoló centromerikus heterokromatinhoz, azon belül is egy $1,686 \mathrm{~g} / \mathrm{cm}^{3}$ fajsúlyú $10 \mathrm{bp}$-os szatellita (ProdSat) ismétlődéshez, ahol elengedhetetlen a normális kromoszóma kondenzációhoz. A Prod a heterokromatinon közvetlenül, gyenge affinitással és szekvencia specificitással, kooperatívan köti a DNS-t. Nincs jól jellemezhető DNS-kötő doménje, a fehérje 2/3-a szükséges a DNS kötéshez. A szekvencia-specificitás elveszik, ha a fehérje Nterminális 74 aminosava hiányzik, de a kooperatív DNS-kötés megmarad. Egyetlen coiledcoil domén ismerhető fel a fehérje közepén, ami fehérje-fehérje interakcióban vehet részt. Szekvencia analízis alapján a Prod regulátora nagy valószínüséggel PRE-t (Polycomb Response Element) tartalmaz, vagyis a Polycomb csoport részt vehet a Prod finom regulációjában, esetleg a Prod is része lehet valamely Polycomb komplexnek. A ProdSat-on kívül a fehérje több mint 400 eukromatikus helyen és az összes telomeren kimutatható immunfestéssel, azonban eukromatikus funkciója ez idáig ismeretlen. Munkám során elsősorban a Prod fehérje telomerikus szerepét vizsgáltam.

Az eukarióta telomerek olyan nukleoprotein komplexek, melyek védik a lineáris kromoszómák végeit a degradációtól és a fúziótól, valamint kiegyensúlyozzák a tökéletlen replikáció természetéből adódó rövidülést. Az ecetmuslica (Drosophila melanogaster) kromoszómavégei telomeráz által generált ismétlődések helyett telomer-specifikus retrotranszpozonokat tartalmaznak. Ecetmuslicában a telomeráz enzim teljesen hiányzik, így a telomer három, terminális ismétlődést nem tartalmazó non-LTR retrotranszpozon ( $\underline{H} e T-A$, TART és TAHRE, továbbiakban HTT) kromoszómavégre történő célzott transzpozíciójával, valamint ezen elemek közötti homológ rekombinációval hosszabbodik. Szerkezetileg az ecetmuslicában három telomerikus domént tudunk megkülönböztetni: a kromoszómális DNS molekula szabad végét; a retrotranszpozon ismétlődést (HTT sor), valamint a szubtelomerikus heterokromatint, a TAS-t. Bár a telomerikus DNS szekvenciák jól ismertek, a fehérje alkotókról szerzett tudásunk még messze nem teljes. A nagyszámú fehérjéből álló terminális 
capping komplex szekvencia-specificitás nélkül kapcsolódik a kromoszómavégekhez, és megvédi a kromoszómavéget attól, hogy azt a DNS repair mechanizmus kettős szálú törésként ismerje fel. A HTT domént nyíltabb, eukromatin-szerü szerkezet jellemzi, a retroelemek fejfarok irányultságban helyezkednek el, az oligo(A) farkukkal mindig a centromer felé nézve. A retrotranszpozon sor hosszát és összetételét tekintve jelentős különbség lehet az egyes kromoszómavégek és egyes törzsek között is, de a telomerek hossza egy bizonyos határig genetikailag szabályozott az ecetmuslicában is. A hosszkülönbségek jelentősége és következményei még nem tisztázottak, de a túlságosan hosszú HTT sor csökkenti a termékenységet. A szubtelomerikus ismétlődő szakasz (TAS) - amely a HTT doménnel közvetlenül szomszédos és attól proximális irányban helyezkedik el - 15-26 kb hosszúságú, és olyan komplex repetitív blokkokból áll, melyek kromoszómánként némileg eltérő szekvenciájúak. A TAS-t bizonyítottan a heterokromatikus, vagyis a szorosan csomagolt kromatinszerkezet jellemzi, így képes HTT retrotranszpozonok aktivitását befolyásolni.

A fent vázolt telomerikus domének nem csak a DNS szekvencia, hanem a hozzájuk kapcsolódó kromatin fehérjék szintjén is elkülöníthetőek. Hogy megértsük a telomerhossz szabályozásának mechanizmusát, elengedhetetlen feladat a telomerikus kromatint alkotó fehérjék azonosítása. A HTT sorhoz kapcsolódó fehérjéket nehéz azonosítani, mert ellentétben a capping fehérjék mutánsainak telomer fúziós fenotípusával vagy a TAS-hoz kapcsolódó fehérjék mutánsainak PEV módosító hatásával, a HTT-kötő fehérjék génjeinek nincs megjósolható mutáns fenotípusa, ami egy hatásos genetikai szürés előfeltétele lenne. Ezért az egyik lehetséges módszer az immunfestéssel telomerikus lokalizációt is mutató ismert kromoszómális fehérjék részletes vizsgálata marad. Ily módon eddig három fehérje került azonosításra, a Prod mellett a Z4 és a JIL-1. Bizonyított, hogy a capping alkotó HP1 kis koncentrációban ugyan, de a HTT és a TAS doménen is kimutatható kromatin immunprecipitációval. A HP1 és a Prod lehetséges szerepe a HTT soron már részben tisztázott, de a Z4 és JIL-1 fehérjéké még ismeretlen.

Célunk a Prod eukromatikus lókuszokon és a telomereken betöltött szerepének tisztázása volt. Sejtbiológiai, molekuláris biológiai és biokémiai módszerekkel terveztük azonosítani a Prod pontos helyét a telomeren. Mivel a Prod nagy valószínűséggel nem egyedül, hanem több más fehérjével együtt, komplexben található meg a telomerikus kromatinban, célul tüztük ki Prod-dal kölcsönható fehérje partnerek azonosítását. Erre élesztő két-hibrid szürést alkalmaztunk, majd a kölcsönhatást biokémiai és immunfestési kísérletekkel próbáltuk igazolni. 
Ecetmuslica lárva nyálmirigy politén kromoszómáinak immunfluoreszcens festése alapján a Prod fehérje számos eukromatikus helyen túl egyértelmúen kijelöli az összes telomert. A telomerek Prod festődési mintázata jól megfelel a HeT-A próbákkal történt in situ hibridizáció eredményének, ez a Prod-HeT-A kapcsolatra utaló jel azonban önmagában nem zárja ki a többi telomerikus szekvenciához való lehetséges kötődést. Az X kromoszómáján TAS-deletált yellow ${ }^{1}$ törzs Prod immunfestése alapján a Prod fehérje a TAS domén hiányában is kötődik a telomerekhez, ez azonban nem zárja ki a TAS-hoz való kötődést. A domináns Tel mutációt tartalmazó törzs a vad típusnál mintegy tízszer hosszabb HTT doménnel rendelkezik, ami föleg a HeT-A retrotranszpozon megnövekedett példányszámának köszönhető. Ezt a törzset vad típusú Oregon-R törzzsel keresztezve olyan heterozigóta telomereket állíthatunk elő, melyeknek a hosszú HTT-t hordozó Tel homológja jóval túlnyúlik a rövidebb Oregon-R homológon. A Prod festődés a túlnyúló HTT sor teljes hosszán látható, tehát a Prod fehérje a HTT doménhez kapcsolódik. A TAS-t és a terminális retrotranszpozonokat egyaránt eltávolító deficiencia esetében a Prod fehérje telomerikus jelenléte megszünik. Mivel ezekben az esetekben a terminális cap ép marad, ez bizonyítja, hogy a Prod fehérje nem része a terminális capping komplexnek.

A citológiai bizonyítékokon túl kromatin immunprecipitációval is igazoltuk a Prod fehérje és a HeT-A szekvenciák kölcsönhatását. Az UV- és FA-keresztkötött embrió kromatinból kinyert DNS-t ${ }^{32}$ P-jelöltük és egy olyan Southern blot-hoz hibridizáltuk, amely a teljes HeT-A szekvenciát azonosított helyzetű szubklónok formájában tartalmazta. Ez alapján a Prod közvetlenül a $H e T-A$ promóter régió elé kötődik, ami a Prod a $H e T-A$ transzkripcióban betöltött lehetséges szabályozó szerepére enged következtetni.

Ezért kvantitatív PCR (qPCR) segítségével megvizsgáltuk, hogy a $\mathrm{prod} / \mathrm{CyO}$ heterozigóta legyekben megváltozott-e a HeT-A kópiaszáma. A mérésekből arra lehet következtetni, hogy a prod géndózis 50\%-os csökkenése nem befolyásolja a transzpozíciók gyakoriságát. Ez után arra voltunk kíváncsiak, hogy a HeT-A transzkripciós szintje megváltozhatott-e ezekben a heterozigótákban a vad típushoz képest. Ezt kvantitatív reverztranszkripciós-PCR-el (qRT PCR) vizsgáltuk és azt tapasztaltuk, hogy a mért HeT-A transzkriptum szint $\operatorname{prod}^{k 08810} / C y O$ esetében 6,5-ször, míg prodH/CyO esetében 12,5-ször magasabbnak bizonyult, mint az Oregon-R kontrollban. Ezen eredmények alapján a vad típusú Prod fehérje represszió alatt tartja a $H e T-A$ transzkripciós szintjét, de expressziós szintjének 50\%-os csökkenése mégsem emeli a transzpozíciók gyakoriságát.

Az élesztő kettős hibrid rendszerrel végzett kísérlet során a teljes prod cDNS-t használva csaliként sikeresen azonosítottunk Prod-dal kölcsönható fehérjéket, melyek közt 
megtalálható maga a Prod fehérje is, így most közvetlen igazolást nyert az, hogy a Prod multimerként kötődik a DNS-hez. Azonosításra került a szumoilációs útvonal két fő tagja, ezért feltételezhetjük, hogy a Prod fehérje szumoilálódik, vagy a szumoilációs komplexet köti ki Prod-interaktorok módosításához. A Prod fehérje telomerikus szerepéhez szorosan köthető a Z4 és a Chromator fehérjékkel mutatott kölcsönhatás. A Z4 egyike az ez idáig azonosított telomerikus HTT doménhez kötődő fehérjének, a Chromatort a Z4 fehérjével való interakciója alapján azonosították és leírták, hogy jelen van az X és 2L telomereken.

S2 sejtekkel végzett koimmunprecipitációs kísérletekkel igazoltuk, hogy a Chromator in vivo kapcsolódik a Prod-hoz, és az ismert Chromator-Z4 interakció alapján feltételezhetünk egy közös komplexet, melynek mindhárom fehérje alkotója, legalábbis a kromoszóma azon helyein, ahol kolokalizálódnak.

Immunfluoreszcens festéseket végeztünk Tel/Oregon-R hibrid politén kromoszómákon, melyek során megerősítést nyert, hogy a Z4 kötődik a HTT-hez és kimutattuk, hogy a Chromator is jelen van az összes telomeren. További festésekkel igazoltuk, hogy a telomeren belül mindkét fehérje a HTT sorhoz kötődik, vagyis a HTT domén lehet a potenciális Z4/Chromator/Prod fehérje komplex elsődleges célpontja.

Az élesztő két-hibrid adatok alapján a Prod kölcsönhatásba léphet a szumoilációs enzim kaszkád két legfontosabb tagjával, az Uba2 és az lwr fehérjékkel. Mivel az Smt3 az egyetlen SUMO homológ ecetmuslicában, egy anti-Smt3 ellenanyaggal való festéssel azonosíthatóak a szumoilált fehérjék a politén kromoszómákon. A már említett festési módszerekkel megvizsgáltuk ezen módosítás jelenlétét és eloszlását a telomereken. Az Smt3 telomerikus lokalizációja jelzi, hogy a HTT sor erősen szumoilált. A telomerek szumoilációs mintázata egybevág a Prod lokalizációval, azaz az Smt3 végig megtalálható a HTT soron, de nem kapcsolódik a TAS-hoz és nem része a telomerikus cap-nek sem.

A HTT domén kromatin állapota a retrotranszpozíció és a génkonverzió szabályozásán keresztül befolyásolhatja a telomer hosszát. Heterozigóta mutánsokban a fehérje koncentráció a felére csökken, ami mutáns fenotípus megjelenéséhez vezethet, ha a fenotípus kellően érzékeny a géndózisra. Esetünkben a telomerikus fehérjék heterozigóta törzseiben ez megváltoztathatja a telomerek hosszát. Ennek vizsgálatára kvantitatív PCR segítségével megmértük a mutáns heterozigóták HeT-A tartalmát, és összehasonlítottuk a vad típussal. Kísérletünk eredményéből kiderült, hogy a csökkent mennyiségü Prod és a Chromator null allél a vad típusnál némileg hosszabb telomert okoz, míg a Z4 és SUMO redukált szintje nincs hatással a telomerhosszra. Tehát a kromatin szerkezetében vagy a HTT fehérjék 
szumoiláltságában bekövetkező változás nem feltétlenül elég a transzpozíciók vagy a génkonverzió gyakoriságának megemeléséhez a telomereken.

Az eddig ismert adatok és a kísérleti eredményeink alapján létrehoztuk a Drosophila telomerek HTT doménjének lehetséges müködési modelljét. A HTT domén fehérje interakciónak központi mediátora a Chromator lehet, amely közvetlenül kölcsönhat a Prod, a JIL-1 és Z4 fehérjékkel. A Z4 a DREF komplex része lehet, a Prod pedig multimerként specifikusan kötődik a HeT-A promótert közvetlenül megelőző szakaszhoz. A Prod horgonyozhatja ki a szumoilációs komplexet, és ezzel módosíthatja a különböző komplex alkotók kötési sajátosságait. A szumoilált Eggless metilálja a H3 hisztont a 9. pozícióban lévő lizinjén, mely módosítást felismerve kötődik ide a HP1 és gátolja a transzkripciót. 


\section{SUMMARY}

The proliferation disrupter gene (prod) of the fruit fly encodes a 346-amino-acid DNA-binding chromosomal protein that localizes strongly to the centric heterochromatin of the second and third chromosomes, as well as to $>400$ euchromatic sites, and to all telomeres. The Prod protein strongly binds to the heterochromatic regions neighbouring the centromeres of the second and third chromosomes, more specifically to a $1.686 \mathrm{~g} / \mathrm{cm}^{3} 10-\mathrm{bp}$ satellite (ProdSat), where it is indispensable for normal chromosome condensation. Prod cooperatively binds DNA directly on the heterochromatin, with low affinity and sequence specificity. The protein does not have a well-defined DNA-binding domain, 2/3 of the protein is needed for adequate binding. When the $74 \mathrm{~N}$-terminal amino acids are deleted, the sequence-specificity of the binding is lost, however the cooperative DNA-binding remains. Only one coiled-coil domain can be identified in the central region of the protein, which might play a part in protein-protein interactions. Based on sequence analysis, the regulator of Prod very likely contains a Polycomb Response Element (PRE), meaning that the Polycomb group may play a role in the fine-tuning of Prod regulation, or that Prod itself may be part of one of the Polycomb complexes. Besides ProdSat, the presence of Prod can be shown by immunostaining at over 400 euchromatic loci, as well as all telomeres. The euchromatic role of Prod is so far unknown. In my work, I primarily investigated the telomeric role of the Prod protein.

Eukaryotic telomeres are nucleoprotein complexes that guard the ends of the linear chromosomes from degradation and fusion, while also balancing the natural shortening of chromosomes resulting from imperfect replication. Instead of telomerase generated repeats, the chromosomal ends of the fruit fly (Drosophila melanogaster) contain telomere-specific retrotransposons. The Drosophila is totally devoid of a telomerase enzyme, instead, the telomere increases in length through the directed transposition to the chromosomal ends and the homologue recombination between three non-LTR retrotransposons ( $\underline{H} e T-A, \underline{T A R T}$, and TAHRE, abbreviated as HTT). Fruit fly telomeres can be divided into three structural domains: the free end of the chromosomal DNA molecule, the retrotransposon repeat (HTT), and the subtelomeric heterochromatin region, the TAS. Although the sequences of the telomeric regions are quite well known, our knowledge about the protein elements are far from complete. The terminal capping complex, consisting of multiple proteins, binds to the 
chromosomal ends without sequence specificity and prevents the DNA repair mechanisms of the cell from recognizing the ends as a double-stranded break. The HTT domains have a more open, euchromatin-like structure, in which the retroelements align in a head-to-tail orientation, with their oligo(A) tail always towards to the centromere. Depending on the chromosome and the strain of the fruit fly, there can be major differences in the length and composition of the retrotransposon regions, however to a certain degree, the length of the telomeres in the fruit fly are also genetically regulated. The relevance and possible consequences of the various lengths are not fully understood, but it is known that a too long HTT region decreases fertility. The subtelomeric repeat region (TAS), which is situated directly neighbouring the HTT domain in a proximal direction, has a length of 15-26 kb, and consists of complex repetitive blocks that show slight differences in sequence from chromosome to chromosome. The TAS region has been shown to consist of tightly packed heterochromatin, thus allowing it to regulate the activity of the HTT retrotransposons.

The telomeric domains described above not only differ in their DNA sequences, but also in their interacting chromatin proteins. To understand the mechanisms regulating telomere length, it is necessary to identify all proteins comprising the telomeric chromatin. Identifying the proteins interacting with the HTT region is however difficult, because unlike the telomere fusion phenotype of capping protein mutants or the PEV altering phenotype of TAS-associated protein mutants, the genes encoding for HTT-interacting proteins do not have a well-predictable phenotype, which is a prerequisite for any effective genetic screen. Therefore the best available strategy is the detailed investigation of known chromosomal proteins that show telomeric localization with immunostaining. In this manner, three proteins have been identified, besides Prod, they are Z4 and JIL-1. It has also been shown that although in a small concentration, the capping protein HP1 can be detected with immunoprecipitation in the HTT and TAS domains. While the roles of HP1 and Prod at the HTT region have been partially identified, less is known about Z4 and JIL-1.

The goal of our work was to identify the role of Prod at euchromatic loci and telomeres. We analysed the precise location of Prod within telomeres using cell biological, molecular biological and biochemical methods. Because Prod, in all likelihood, is found in the telomeric chromatin as part of a complex, we studied the protein-interaction partners of Prod. For this, we used a yeast two-hybrid screen and attempted to validate positive hits using biochemical and immunochemical techniques.

The immunofluorescent staining of polytene chromosomes of larval fruit fly salivary glands showed that besides numerous euchromatic loci, the stained Prod proteins can clearly 
be found in every telomeric region. The Prod staining pattern of the telomeres is identical to the in situ hybridization pattern of the HeT-A probes, indicating a Prod-HeT-A interacting relationship. This by itself does not exclude the possibility of Prod binding to other telomeric sequences. The Prod immunostaining of the yellow strain, which has the TAS region deleted from its X chromosome, shows Prod binding to the telomere, even in the absence of TAS. This by itself does not exclude the possibility of Prod being capable of binding to TAS. A strain carrying the dominant $\mathrm{Tel}$ mutation has an HTT domain almost ten times longer than wild-type, owing mostly to the increased copy number of HeT-A retrotransposons. Crossing this line with a wild-type Oregon-R line produces heterozygote telomeres, where the $\mathrm{Tel}$ homologue with the long HTT domain far overextends the shorter Oregon-R homologue. Immunostaining of Prod shows the protein present on the entire length of the HTT overhang, indicating that Prod binds to the HTT domain. In mutants where in addition to TAS, the terminal retrotransposons are also deleted, the telomeric presence of Prod cannot be shown. Because in such mutants the terminal cap remains intact, it can be concluded that the Prod protein is not part of the terminal capping complex.

In addition to the cytological evidence, we demonstrated the interaction between the Prod protein and HeT-A sequences using chromatin immunoprecipitation. We radiolabeled the UV- and FA-cross-linked embryonic chromatin with ${ }^{32} \mathrm{P}$ and hybridized to a Southern blot that carried the entire $H e T-A$ sequence in the form of subclones each with identified positions. Based on this experiment, we were able to conclude that Prod binds directly upstream of the $H e T-A$ promoter, suggesting a role for Prod in the regulation of HeT-A transcription.

Next, using quantitative PCR (qPCR), we examined whether the HeT-A copy number changes in $\mathrm{prod} / \mathrm{CyO}$ flies. From these experiments, we could conclude that $50 \%$ decrease in the gene dosage of prod does not change the frequency of transpositions. We next wanted to know if the transcription level of HeT-A is different in these heterozygotes compared to the wild type. We examined this using quantitative reverse transcription-PCR (qRT-PCR), and found that in the case of $\operatorname{prodk}^{08810} / \mathrm{CyO}$, the $H e T$-A transcript was 6.5 times the amount found in the Oregon-R control, while in the case of $\operatorname{prodH} / \mathrm{CyO}$, this transcript was 12.5 times the amount present in the Oregon-R control. Based on these results, we can say that the wild type Prod protein represses the transcriptional activity of $\mathrm{HeT}-\mathrm{A}$, but a $50 \%$ decrease in its expression does not increase the frequency of transpositions.

Using the yeast two-hybrid assay, with the complete prod cDNA acting as the bait, we were able to identify the protein interacting partners of Prod, which included Prod itself, indicating that Prod binds to DNA as a multimer. We were also able to identify the two main 
members of the sumoylation pathway, indicating that either the Prod protein itself is sumoylated, or that it binds the sumoylation complex for the modification of other Prod interactors. The interaction of Prod with Z4 and Chromator is a clear indicator of Prod's telomeric role. Z4 is one of the previously identified proteins that bind to the HTT domain of telomeres, while Chromator was identified through its interaction with Z4, and is known to be present at the $\mathrm{X}$ and $2 \mathrm{~L}$ telomeres.

Using co-immunoprecipitation done in S2 cells, we were able to show that Chromator binds to Prod in vivo. Based on the known interaction between Chromator and Z4, we can surmise a common protein complex with all three proteins as members, at least at those positions on the chromosome where the three proteins colocalize.

We performed immunofluorescent staining on Tel/Oregon-R hybrid polytene chromosomes and found that Z4 binds to the HTT region, and that Chromator is present at all telomeres. Further staining showed that within telomeres, both proteins bind to the HTT region, from which we can conclude that the HTT domain can be the primary target of the potential Z4/Chromator/Prod protein complex.

Based on the yeast two-hybrid assay results, Prod interacts with the two most important members of the sumoylation enzyme cascade, the Uba2 and lwr proteins. Because Smt3 is the only SUMO homologue found in the fruit fly, sumoylated proteins on the polytene chromosomes can be identified using an anti-Smt3 antibody staining. Using this technique, we investigated the presence and distribution of sumoylation at telomeric sites. The telomeric localization of Smt3 indicates that the HTT region is strongly sumoylated. The sumoylation pattern of telomeres coincides with Prod localization, that is Smt3 can be found throughout the HTT region, but it does not bind to the TAS region or to the telomeric cap.

The chromatin state of the HTT domain can influence telomere length through the regulation of retrotransposition and gene conversion. In heterozygote mutants, the protein concentration is diminished by $50 \%$, which can lead to a mutant phenotype if the phenotype is sensitive to gene dosage. In this case, in strains heterozygotic for telomeric proteins, the length of the telomeres is modified. To investigate this further, we used quantitative PCR to measure the HeT-A content of the heterozygote mutants and compared to the wild type. We found that a decreased level of Prod and the Chromator null allele slightly increase telomere length compared to the wild-type, while a decrease in the level of Z4 and SUMO do not have effects on telomere length. Thus the changes in chromatin structure or sumoylation of HTT proteins is not sufficient to increase either transposition frequency or gene conversion at telomeres. 
Based on prior knowledge and our own experiments, we were able to construct a working model of the telomeric HTT domains of Drosophila. The central mediator of the protein interaction at the HTT domain is likely to be the Chromator protein, as it directly binds to the Prod, JIL-1, and Z4 proteins. Z4 is proposed to be a part of the DREF complex, while Prod, in multimer form, specifically binds to the region directly upstream of the HeT-A promoter. Prod likely recruits the sumoylation complex, therefore it is able to modify the binding properties of the other members of the complex. The sumoylated Eggless protein methylates the lysine in the $9^{\text {th }}$ position of the $\mathrm{H} 3$ histone, which is then recognized by the HP1 protein, allowing it to bind to this site, ultimately leading to the inhibition of transcription. 